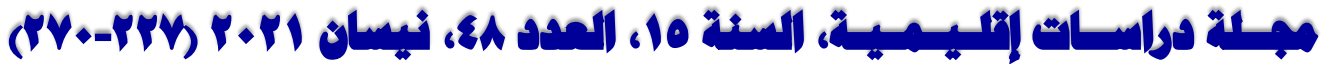

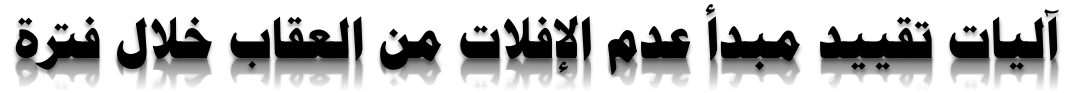

\section{العدالة الانتقالية}

د. فتمي هممد المياني

مدرس / كلية الحقوق/ جامعة الموصل

dr.fathi4175@uomosul.edu.iq
خالد عبد الله علي

مدرس مساءد/كلية الحقوق/ جامعة العوصل khalidkhalidallabd@gmail.com

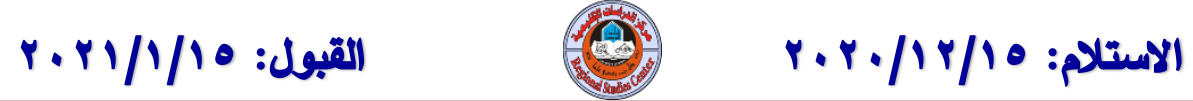

\section{مستخلص البحث}

إن عجز العدالة الجزائية أحياناً بوصفها من آليات العدالة الانتقالية عن تحقيق كامل غاياتها في الردع والإصلاح، دفع إلى التفكير في البديل عن هذه الآلية فكانت العدالة التصالحية هي البديل في التعامل مع التركة الثقيلة من الانتهاكات والجرائم التي خلفها النظام القديم، والتي تقوم على فلسفة مختلفة عن فلسفة العقوبة والجزاء إلى فكرة التصالح والمصالحة ما بين الجاني والمجني عليه والمجتمع، تعتمد العدالة التصالحية فكرة أساسية باستبعاد العقاب ليحل محلة العفو مقابل إقرار الجاني بذنبه وإعفاءه من مسؤولية ما صدر عنه من جرائم وانتهاكات تجاه الضحايا من خلال لجان لكثف الحقيقة مع توفر الإرادة السياسية الحقيقة التي تعمل على ذلك. أن من من من من انتهاج آليات المصالحة الوطنية وتحقيقها من خلال لجان التحقيق والهيئات الفاعلة في المجتمع الاولي. إن انتهاج العفو والمصالحة لا يخلو من مساوئ تترتب عليه ولكنه بالنتيجة يقوم على جملة من التوازنات إذ لا بـ من إعماله من خلال برنامـج متكامل يأخذ بنظر الاعتبار تجاوز سلبيات الماضي دون الاضرار بحقوق الضحايا. الكلمات المفتاحية: العدالة التصالحية؛ العفو؛ المصالحة الوطنية؛ العدالة الانتقالية.

Available online at https://regs.mosuljournals.com/, (c) 2020, Regional Studies Center, University of Mosul. This is an open access article under the CC BY 4.0 license (http://creativecommons.org/licenses/by/4.0/)

Y rv Regional Studies Journal, Vol.15, No.48, April 2021 (227-270) 


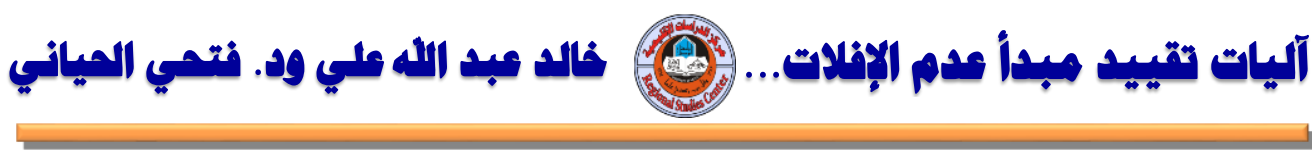

\section{Mechanisms to Restrict the Principle of Non-Impunity During the Transitional Justice Period}

\author{
Khalid A. Ali \\ Assist. lecturer/ Law College / \\ University of Mosul \\ khalidkhalidallabd@gmail.com
}

\author{
Dr. Fathi M. Al-Hayani \\ lecturer/ Law College I \\ University of Mosul
}

dr.fathi4175@uomosul.edu.iq

\section{Abstract}

The inability of criminal justice at times, as one of the mechanisms of transitional justice, to fully achieve its goals of deterrence and reform, prompted the thinking of an alternative to this mechanism. Restorative justice was the alternative in dealing with the heavy legacy of violations and crimes left by the old regime, which is based on a different philosophy from that of punishment and penalty to the idea of reconciliation between the perpetrator and the victim, and society. Restorative justice adopts a basic idea of excluding punishment to be replaced by amnesty in exchange for the perpetrator's admission of his guilt and his exemption from responsibility for the crimes and violations committed against the victims through commissions to uncover the truth with the availability of the real political will for that. The pursuit of national reconciliation mechanisms and their realization through investigation committees and actors in the international community. The pursuit of amnesty and reconciliation has disadvantages, but in the end, it is based on a set of balances as it must be implemented via an integrated program that takes into consideration overcoming the negatives of the past without harming the rights of the victims. Keywords: Restorative Justice; Amnesty; National Reconciliation; transitional justice.

Available online at https://regs.mosuljournals.com/, (C) 2020, Regional Studies Center, University of Mosul. This is an open access article under the CC BY 4.0 license (http://creativecommons.org/licenses/by/4.0/) 


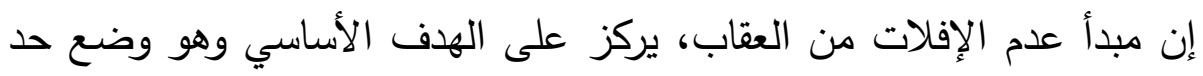
للانتهاكات الجسيمة لحقوق الإنسان، وتحقيق سبل الانتصاف للضحايا، وجبر الضرر

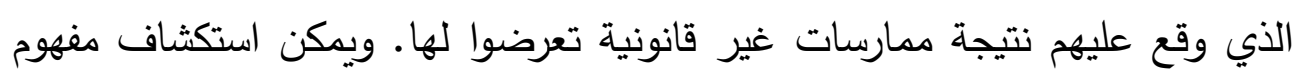

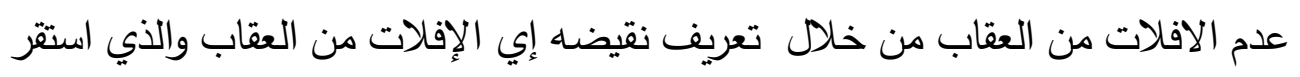

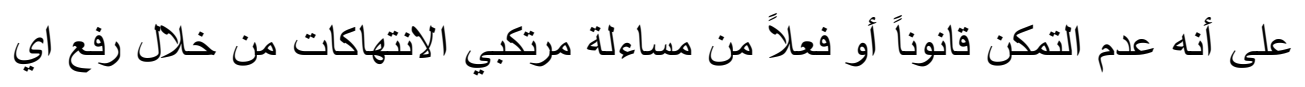

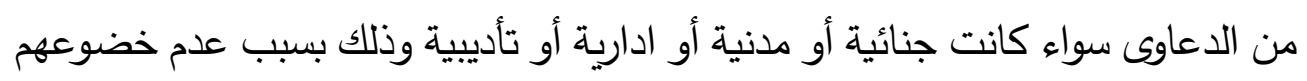

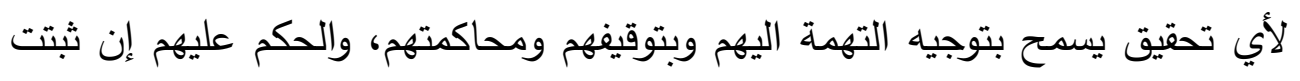

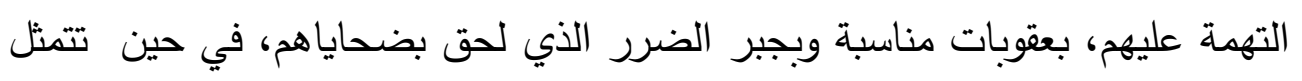

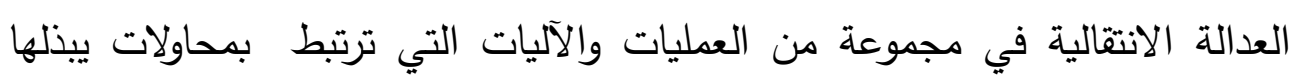

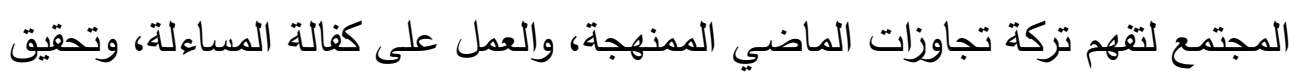

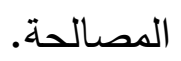

إن الإفلات من العقاب قد يكون أمراً واقعياً بثكل خاص في البلدان التي تثتقر

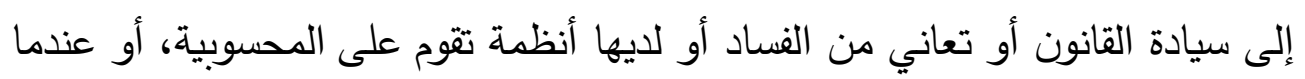

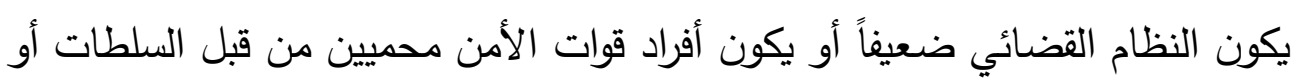
بالحصانات الخاصة، ويقع هذا النوع من الإفلات خارج نطاق اهتمام البعات البحث.

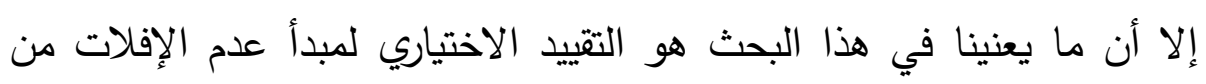

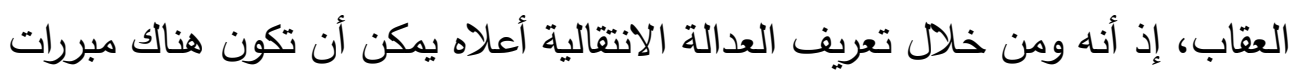

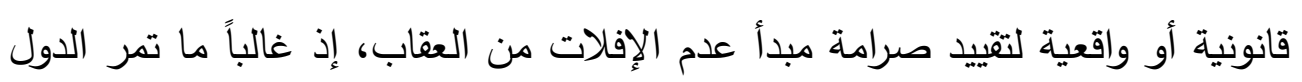

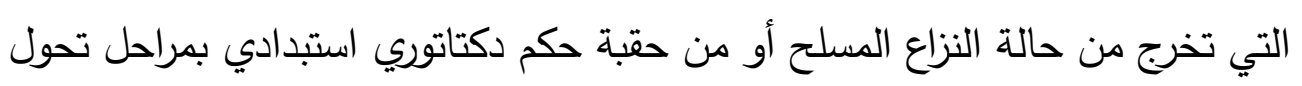

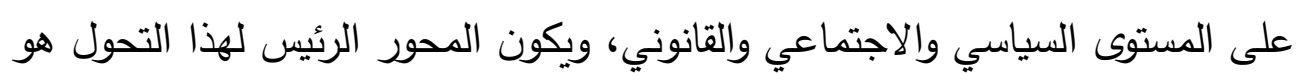

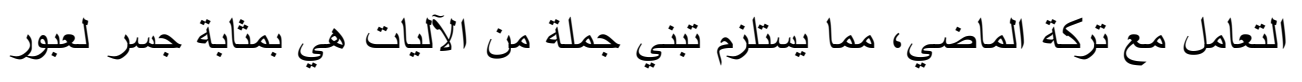

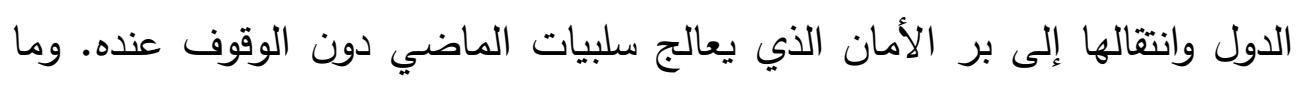

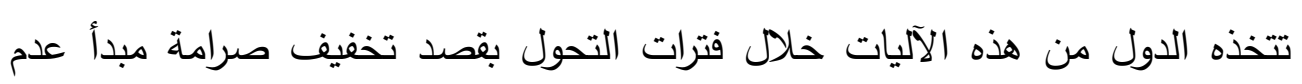




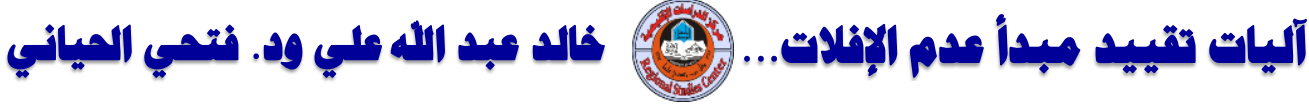

الإفلات من العقاب وتقييده بغية طي صفحة الماضي وبناء مستقبل أكثر استقرارا. ومن ثم يمكن القول أن هذا المبدأ (عدم الإفلات من العقاب) ليس مطلقا وإنما ترد عليه بعض التقييدات في ضوء الفلسفة التي يتبناها النظام السياسي الجديد فيما يتعلق بالسياسة العقابية، والغرض من العقوبة فيما إذا كانت ترتكز على القصاص والردع بثقيه العام والخاص، أو أنها ترتكز على إصلاح الجاني وتصالحه مع المجني ومع المجتمع الذي أضرت الجريمة بسلمه الاجتماعي، إذ قد تطرأ احياناً ضرورات معينة

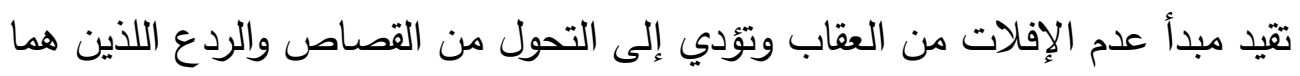
هدفان أساسيان لفلسفة العقاب إلى الإصلاح والتصالح، أو الانتقال من العدالة الجزائية

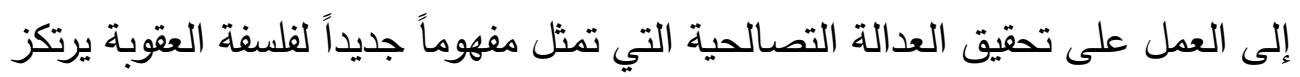
على إنصاف المجني عليه إضافة إلى الاهتمام بالجاني بغية إصلاحه وإعادة إدماجه في المجتمع، إلى جانب الاهتمام بالمجتمع نفسه وضمان استقراره وسلمه، وإثاعة الألفة إلة إلها والانسجام بين مكوناته، وقطع دابر كل ما يعكر صفوه.

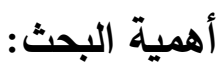

تكمن أهمية البحث في الوقوف على أهم مواطن الضعف والقوة التي تلازم تقييد مبدأ عدم الإفلات من العقاب، خلال مرحلة العدالة الانتقالية من خلال تسليط الضوء على كيفية تقييد المبدأ وماهي الحدود التي يتم الوقوف عندها في تقييد المبدأ، والمبررات التي تحاول الدول التذرع بها من أجل محاولة تقييد المبدأ كالدفع بمبدأ السيادة والحصانة، وأيضاً عدم التعاون الدولي، وتجدر الإشارة الى أهمية العديد من التجارب التي سلكت اجت مبدأ التقييد والتي أثتتت النجاح في خوض تلك التجربة ويشار إلى تجربة جنوب أفريقيا التي تعد المثال الذي يحتذى باه في ذلك.

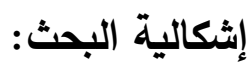

يحاول هذا البحث الإجابة على التساؤلات الاتية: ماهي التدابير التي يمكن أن تتخذ لتقيد مبدأ عدم الإفلات من العقاب؟ وما هي مبرراتها الفلسفية والواقعية؟ وما هو 


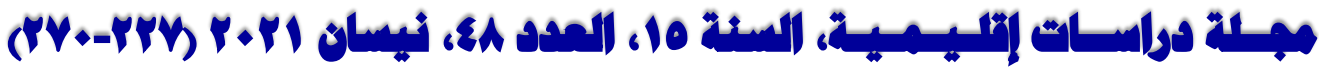

مدى شرعيتها ومدى ملازمتها لتحقيق الموازنة بين هذا التقيد وحقوق الضحايا في جبر الضرر خلال مرحلة العدالة الانتقالية؟ مدئ

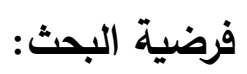

يمكن تقييد مبدأ عدم الإفلات من العقاب خلال مرحلة العدالة الانتقالية من خلال عدم التركيز على نهج العدالة الجزائية تحقيقاً لغايات تتعلق بيناء الدولة وطي صفحات الماضي وصولاً إلى السلم المجتمي بما لا يفرط بحقوق الضحايا.

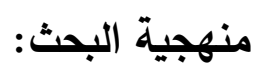

لتشعب جزئيات البحث سيتم استخدام منهجين مختلفين يكمل بعضهما الآخر ففي المقام الأول سوف يتم اعتماد المنهج الاستقرائي كمسلك لتتبع جزئيات البحث واستقرائها بغية الوصول الى القواعد والمبادئ العامة، دون إغفال الاستعانة بالمنهج الاستنباطي كسبيل لاستكثاف تطبيقها ومدى فاعليتها. هيكلية البحث:

سنقوم بتقسيم بحثنا إلى مبحثين وكل مبحث إلى مطلبين وكالآتي:

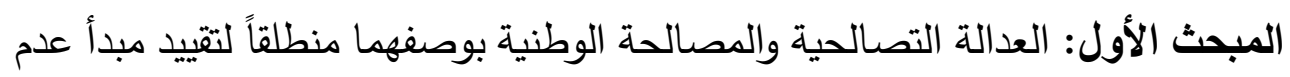
الإفلات من العقاب. المطلب الأول: العدالة التصالحية بوصفها منطلقاً لتقييد مبدأ عدم الإفلات من العقاب وآليات تطبيقها. المطلب الثاني: المصالحة الوطنية بوصفها منطلقاً لتقييد مبدأ عدم الإفلات من العقاب وآليات تطبيقها. المبحث الثاني: تدابير العفو خلال فترة العدالة الانتقالية. المطلب الأول: تعريف العفو وأشكاله. المطلب الثاني: شرعية منح العفو خلال فترة العدالة الانتقالية ودوره في تتييد مبدأ عدم

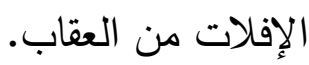




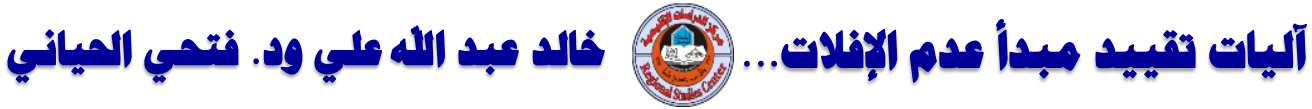

\section{المبحث الأول}

\section{العدالة التصالحية والصالمة الوطنية بوصفهيما هنطالقًا لتقيسد هبداً عدم}

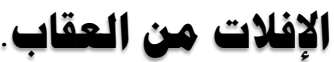

إن مبدأ عدم الإفلات من العقاب يتأرجح بين الإطلاق والتثييد بحسب الفلسفة

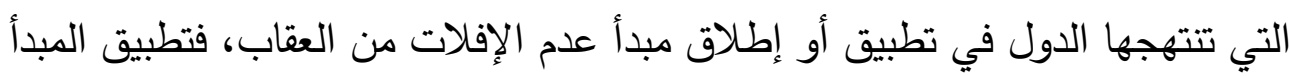

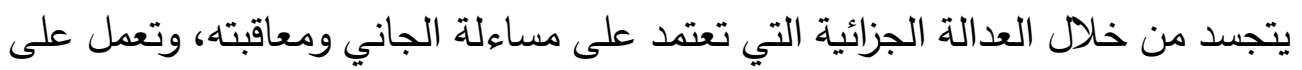
مواجهة خطورة الجاني من خلال تحقيق أغراض العقوبة من ردع خاص وعام، وإعادة تأهيل المجرم تمهيداً لإدماجه في المجتمع. وفلسفة العدالة الجزائية مؤداها أن ثقافة دافي المساءلة تحل محل ثقافة الإفلات من العقاب التي سمحت بارتكاب الانتهاكات، مما

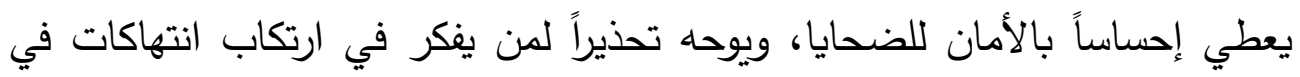

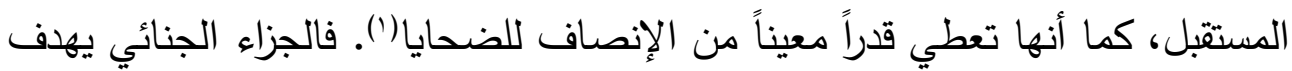
عموماً إلى تحقيق غاية بعيدة وهي حماية المجتمع من الجريمة عن طريق إصلاح الجاني وتهذيبه أو علاجه، ومنعه من العودة إلى الجريمة مرة أخرى(؟).

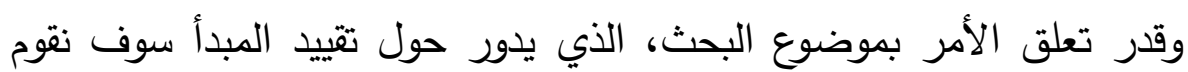
بتقسيم المبحث إلى ثلاث مطالب: المطلب الأول يتتاول مفهوم العدالة التصالحية كمنطلق لتقييد مبدأ عدم الإفلات من العقاب وآليات تطبيقها أما المطلب الثاني فسيكون تدابير المصالحة الوطنية كمنطلق لتقييد مبدأ عدم الإفلات من العقاب وآليات تطبيقها

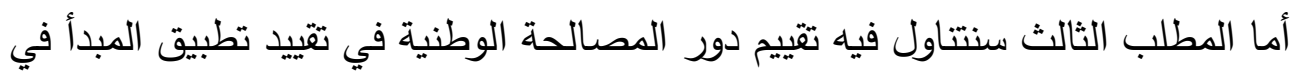
العراق وفي ضوء بعض التجارب الدولية. المطلب الأول: العدالة التصالحية بوصفها منطلقاً لتقييد مبدأ عدم الإفلات من العقاب وآليات تطبيقها

إن عجز العدالة الجزائية أحياناً كآلية من آليات العدالة الانتقالية عن تحقيق كامل غاياتها في الردع والإصلاح، وتزايد ظاهرة الإجرام واتساع الانتهاكات كماً ونوعاً، والعجز عن تحقيق السلم المجتمعي وتهديد هذا السلم في حال الإصرار على إبقاء 


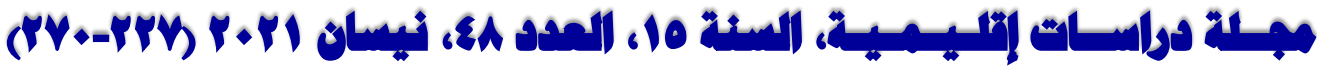

العقاب- كما في تجربة الأرجنتين(r) كل ذلك أدى إلى التفكير في البديل عن هذه الآلية

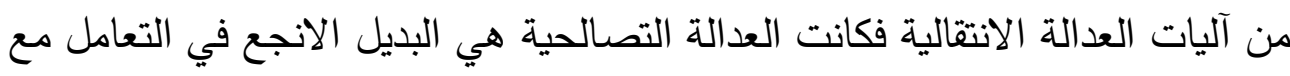

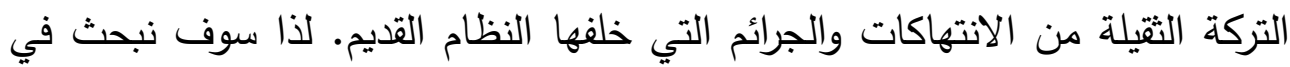
العدالة التصالحية كمنطلق لتقييد المبدأ من خلال تقسيم هذا المطلب إلى ثلاثة فروع: الفرع الأول يتناول مفهوم العدالة التصالحية والفرع الثاني سوف نتتاول فيه فلسفة العقوبة في سياق النهج التقييدي لمبدأ عدم الإفلات من العقاب أما الفرع الثالث فسوف يدرس آليات تطبيقها.

الفرع الأول: مفهوم العدالة التصالحية التية العدالة التصالحية عملية متحركة متغيرة وفي تطور مستمر ، ولهذا فمن الصعب وضع تعريف شامل ومحدد لها، إلا أن هناك سمات معينة ترتبط بالعدالة التصالحية بشكل عام ومن بين هذه السمات توفير الفرص لتشاطر التجارب، والتركيز على إصلاح

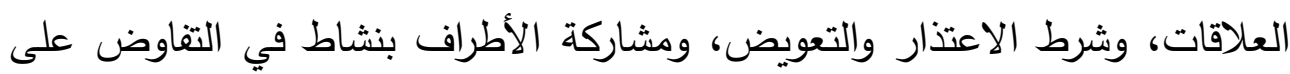

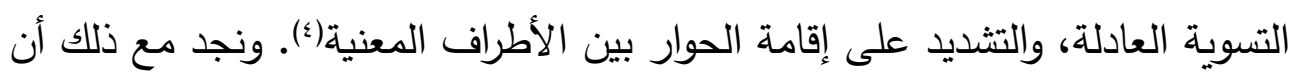

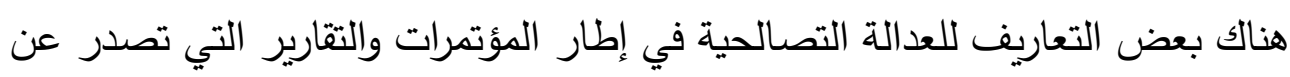

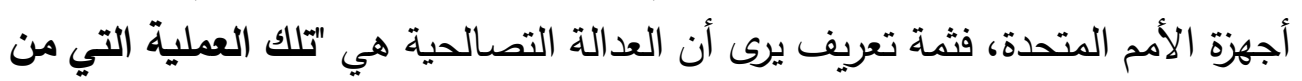

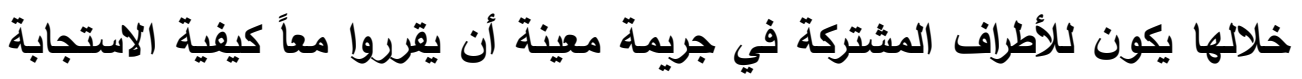

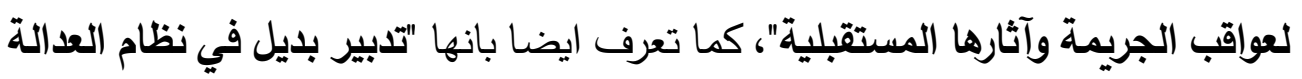
الجنائية وهي ليست عقابية في طبيعتها، بل تسعى إلى إقامة العدل على الجناة

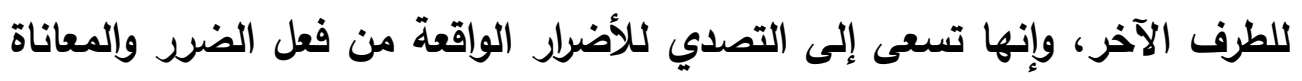

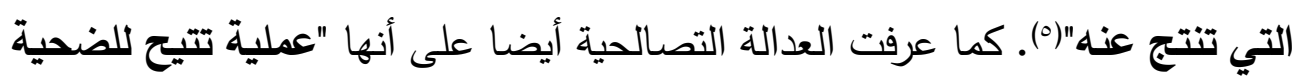
والجاني وأي أشخاص آخرين متأثرين بالجريمة أن يشاركوا في تسوية المسائل الناشئة

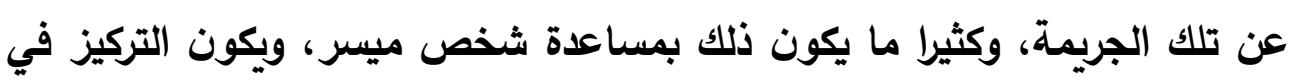
هذه الحالات على الاحتياجات الفردية والجماعية، وعلى إعادة إدماج الضحية والجاني

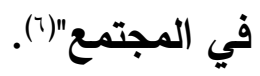




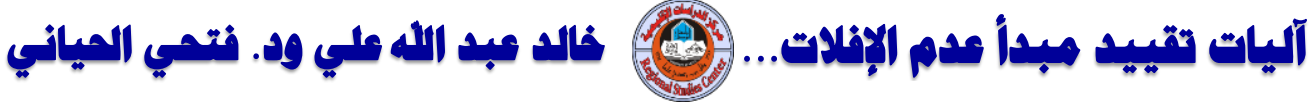

يتضح من التعاريف أعلاه أن العدالة التصالحية تأخذ بالحسبان حاجة كل من

الضحية والجاني والمجتمع في إجراءاتها، فبالنسبة للضحية حاجته بالانتصاف وجبر الضرر، وللجاني حاجته في إعادة التأهيل والإدماج من جديد في المجتمع، أما حاجة وإنانه

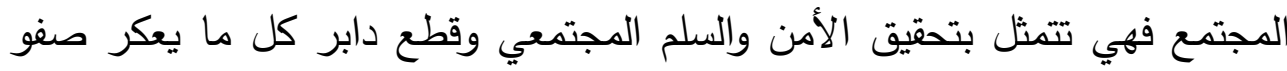
التعايش فيه، والعمل على إعادة العلاقات بين مكونات المجتمع إلى سابق عهدها قدر الإمكان بعد أن عكرت صفوها الجرائم والانتهاكات.

الفرع الثاني: فلسفة العقوبة في سياق النهج التقييدي لمبدأ عدم الإفلات من العقاب لقد زاد الاهتمام في السنوات الأخيرة بالعدالة التصالحية كنهج بديل لممارسات

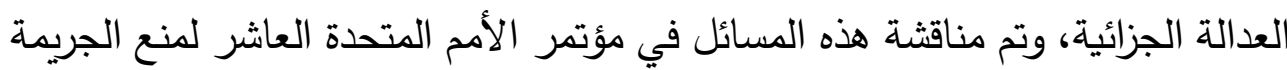

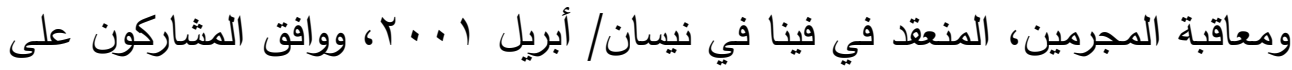

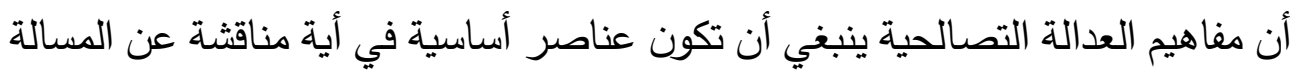
والإنصاف للجناة والضحايا في إجراءات العدالة، وكانت الفلسفة الكامنة وراء العدالة

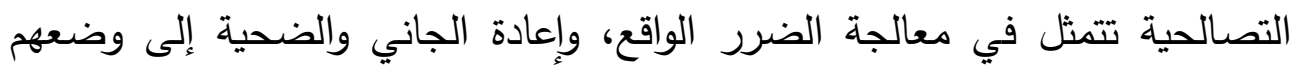

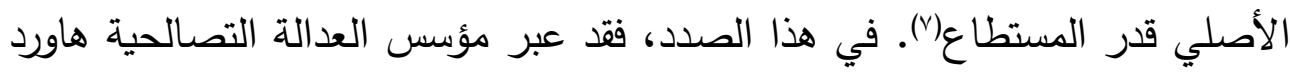
زهر Howard Zehr عن فثل العدالة الجزائية التي أغفلت دور الضحية في الوصول فولين إلى تحقيق العدالة، على عكس العدالة التصالحية التي ترتكز في الأساس على الضحية،

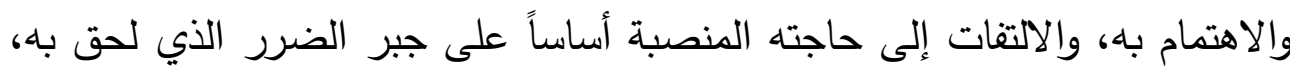

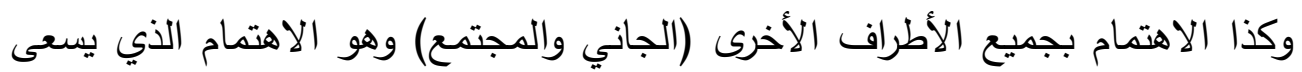
الى استعادة العلاقة بين الجميع من خلال جبر الضرر الناجم عن الجريمة والادماج الاجتماعي لمرتكبها، وإرساء السلم في المجتمع(^). وتجدر الإشارة إلى أن هناك رأي الئ يعتقد أن العدالة التصالحية موغلة في القدم، فالأشكال التقليدية والفطرية لها كانت التهاء أساساً ترى الجريمة على أنها أذى يصيب الناس، وترى العدالة على أنها تعيد التوافق والتوازن

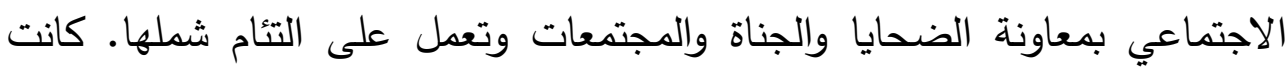
الاتجاهات التصالحية تشغل مكاناً بارزاً في المدونات القانونية للحضارات التهات التي كانت 
الأساس للنظم القانونية الحديثة، حيث إن هناك عناصر تصالحية في جميع النظم

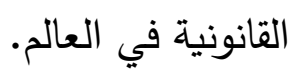

وقد جرت في السنوات الاخيرة اعادة تقييم للعلاقات بين الجناة والضحايا والدولة

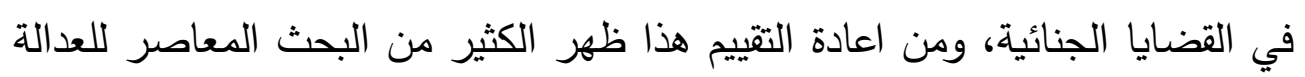

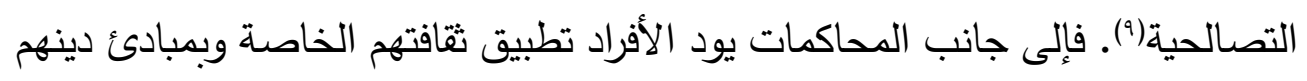

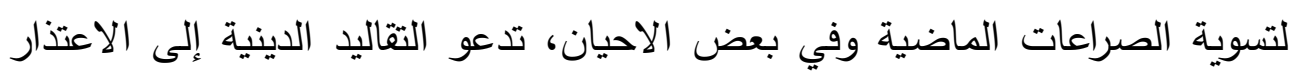

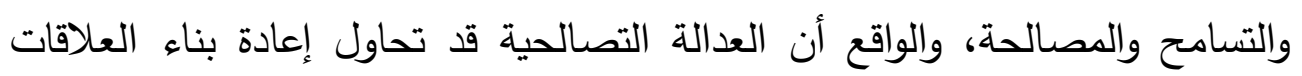

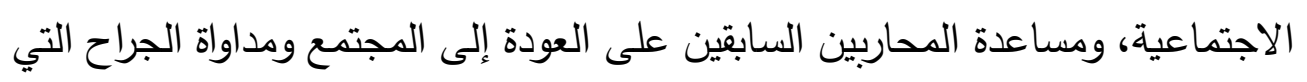

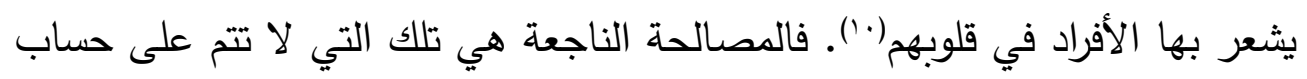

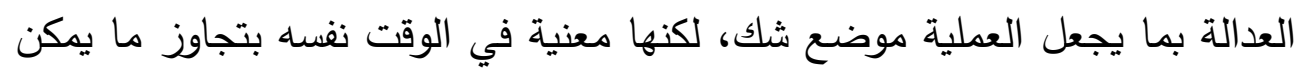

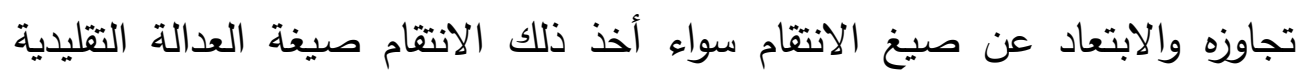

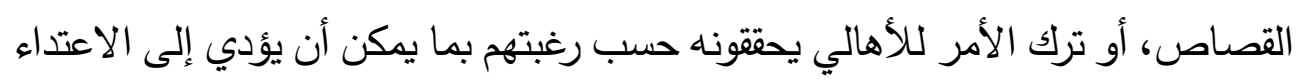

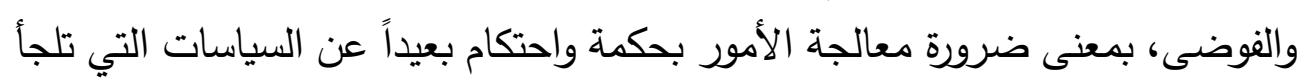
اليها بعض الحكومات التي تثرف على عدالة انتقالية(').

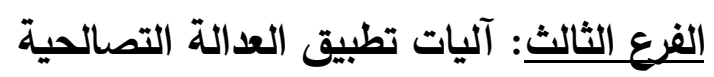

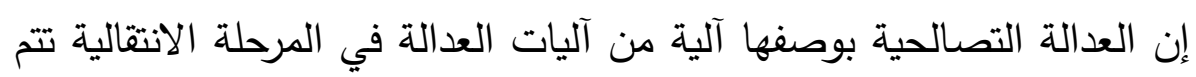

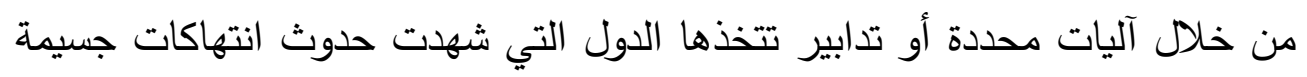

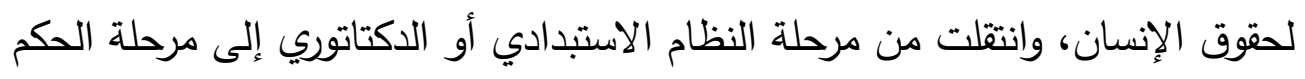

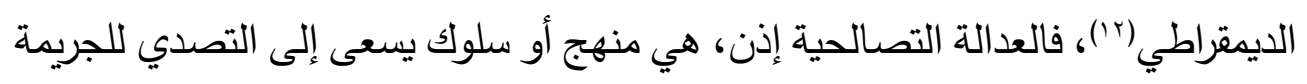

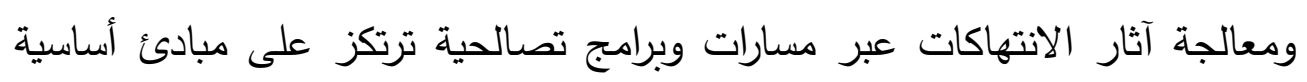

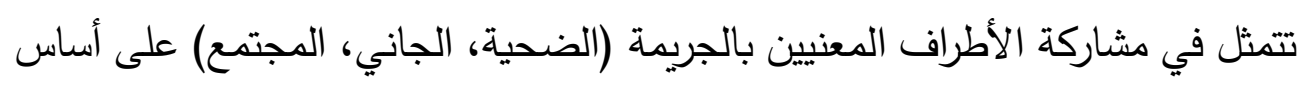

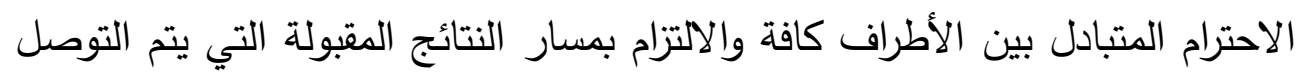

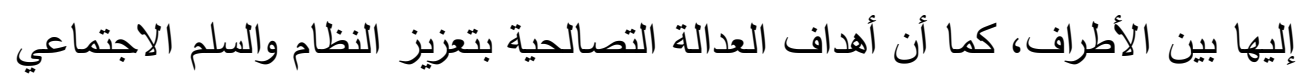

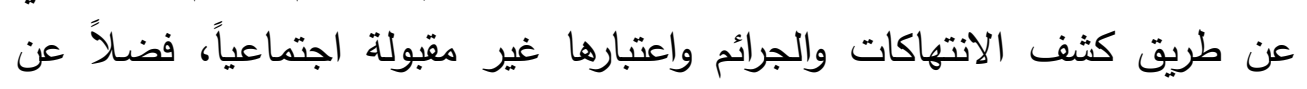

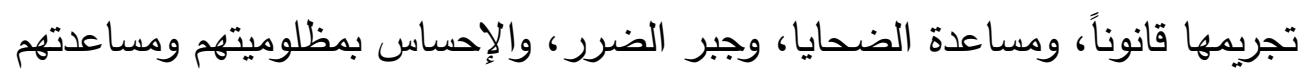




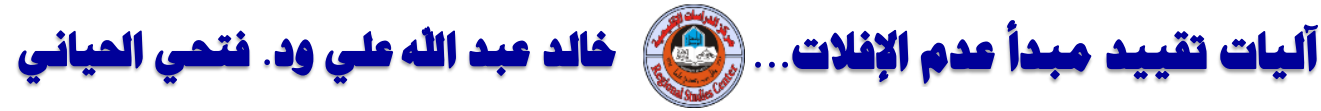

في تحقيق مطالبهم، وتحمل المسؤولية من الجميع وبخاصة الجاني، وإبداء الاعتذار

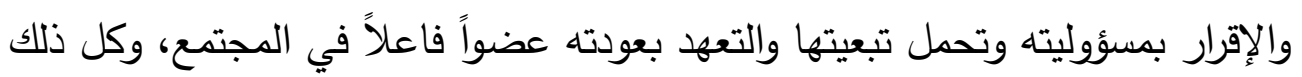

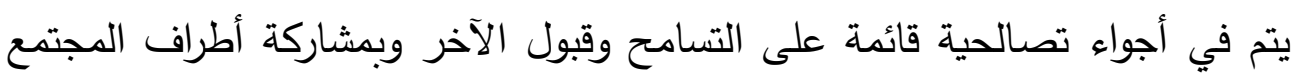
عن طريق ممثليهم في التسوية التي تتم(r'). وتعد لجان الحقيقة من أهم الآليات الفاعلة في سياق العدالة التصالحية، وذلك فلك من خلال التجارب التي شهدت تثكيل مثل تلك اللجان وهو ما سيتم إيضاحه في هذا الفرع. لاشك أن لجان الحقيقة إذا ما توفرت الإرادة السياسية وأعطيت لها لهانية الحرية والاستقلال الكامل في عملها، هي خير من ينهض بهذه المهمة في سبيل إنصاف الفهان

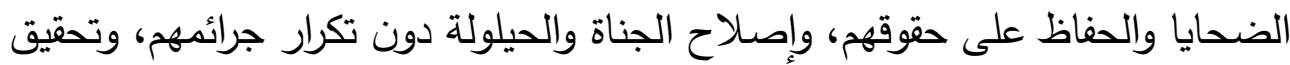
السلم المجتمعي، ومن ثم تساعد أعمال لجنة الحقيقة المجتمع على الفهم والإقرار بتاريخ كان موضعاً للتنازع والإنكار، وفي سياق ذلك يتم إظهار صوت الضحاعايا وقصصهم

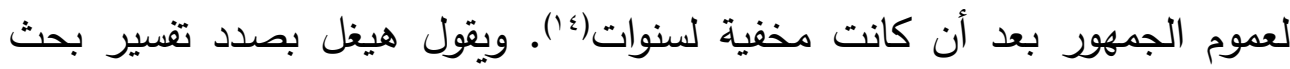
الإنسان الدائم عن الحقيقة (سوف يضل البحث عن الحقيقة يوقظ حماسة الإنسان ونشاطه ما بقي فيه عرق ينبض وروح تشعر ...)، فكيف الحال إذا كان هذا الإنسان ضحية تبحث عن حقيقة وأسباب ما جرى لها على يد جلادها من انتهاكات(10). لقد شكل الكشف عن الحقيقة بغية الوصول إلى أسباب ما وقع ولى من جرائم وانتهاكات، وتقسيره، أحد أهم التحديات الكبرى في تجارب العدالة الانتقالية، وذلك لرغبة الكية الضحايا وعائلاتها في معرفة المتسبب في كل تلك المآسي التي وقعت عليهم، وما هو فولهي مصير المغيبين من ذويهم ومعارفهم، والرغبة في عدم طمس الماضي ومحوه من ذاكرة المجتمع(1'). ومن أهم المقومات المطلوبة للكثف عن دون الحقيقة: ا ـ أن تكون هناك إرادة سياسية حقيقية تسمح وتثجع على تحقيق جدي في الانتهاكات

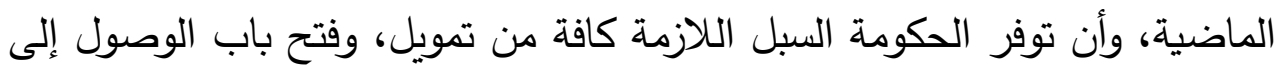

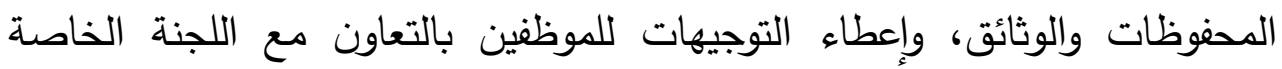
بالتحقيق وعدم عرقلة عملها. 


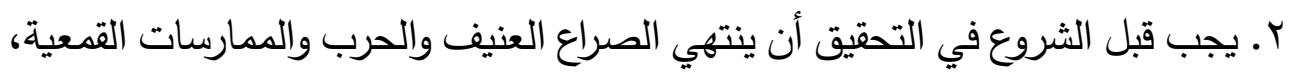

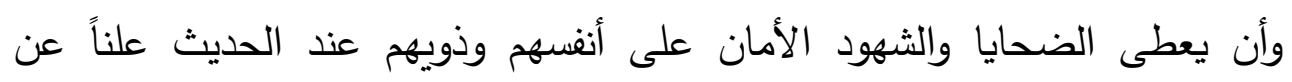

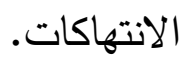

r. يجب أن يكون لدى الضحايا والثهود اهتمام بالوصول إلى الحقيقة، وأن يبدو التعاون

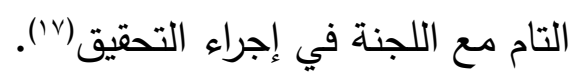
ولا يمكن بغير ذلك الحديث عن كثف الحقيقة والوصول اليها، هذا وإن إنشاء

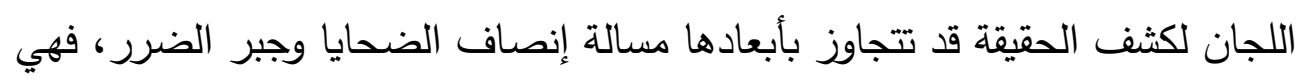

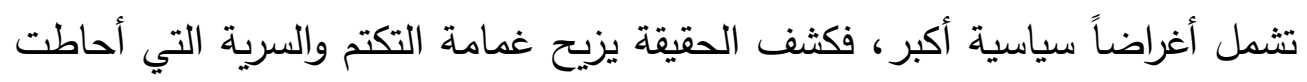

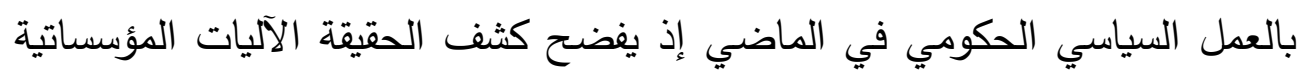

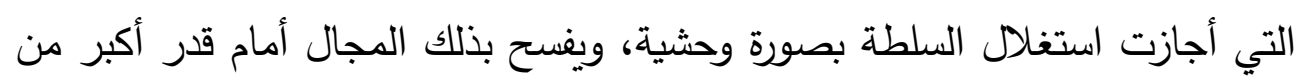
المصارحة والثفافية في العمل السياسي الحكومي يمكن أن تردع وقوع جرائم مماثلة في

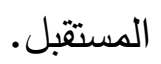

وتعد المصارحة في نهاية المطاف السبيل الأساسي لأخذ العبرة من حقبة الحكم

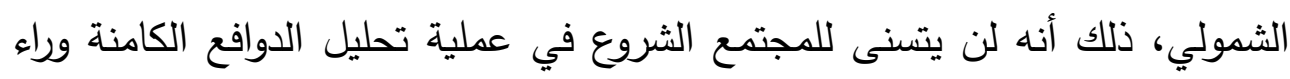

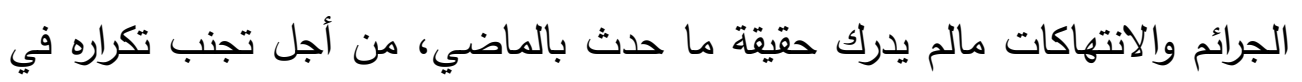

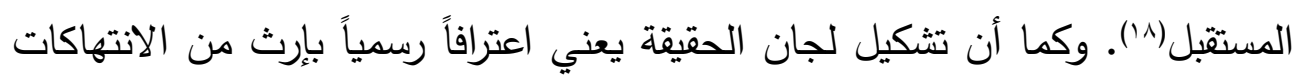

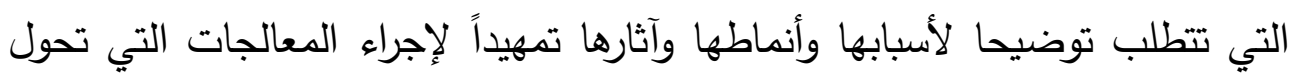

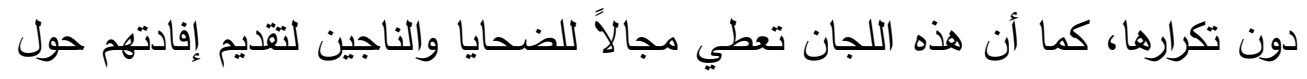

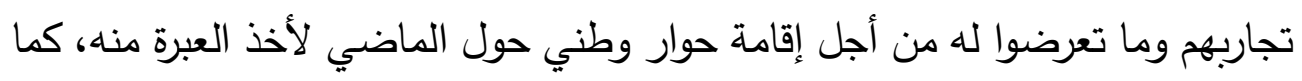

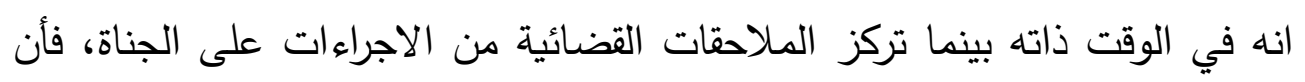

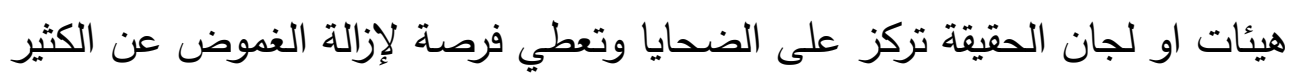

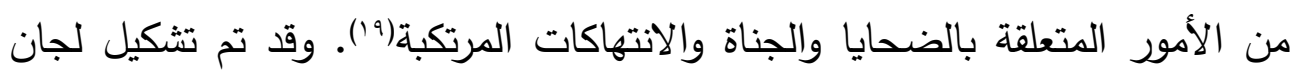

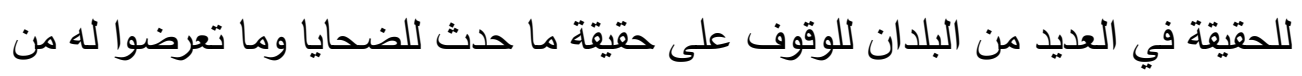

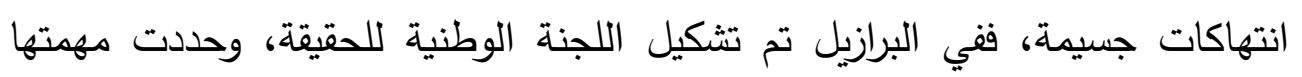

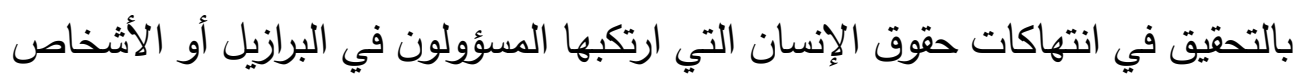




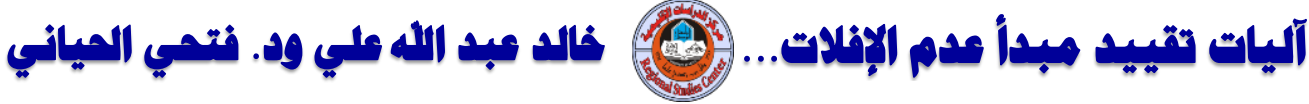

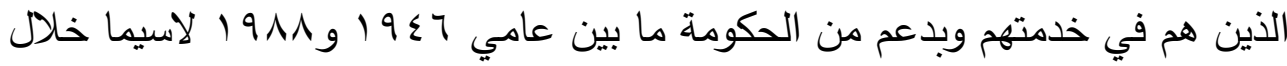
فترة الحكم العسكري، واستمعت اللجنة إلى مجموعة من الثهود والضحايا، ودعت ضباط إنفاذ القانون إلى الثهادة، وتم تنظيم أكثر من مئة جلسة عامة، وتم توثيق ظروف الانتهاكات في تقارير رسمية حددت المواقع والهياكل والمؤسساتية المتعلقة بممارسة الانتهاكات، وعملت على إصدار تقارير وتوصيات بشأن سبل معالجة الانتهاكات، والترويج للمصالحة وتعويض الضحايا وإحياء الذكرى، ومقترحات للعمل على منع تكرار الانتهاكات مستقبلاً، من أجل الوصول إلى بناء مجتمع يسوده السلم الأهلي(·r).

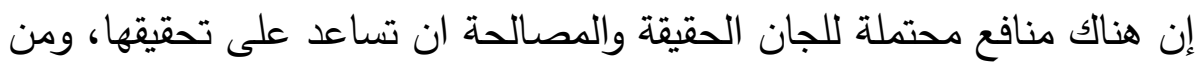
ذلك اثبات الحقيقة بشان الماضي ومحاسبة مرتكبي انتهاكات حقوق الإنسان، وتوفير منبر عام للضحايا، وتحفيز النقاش العام وإثراؤه، والتوصية بتعويض الضحايا، واقتراح

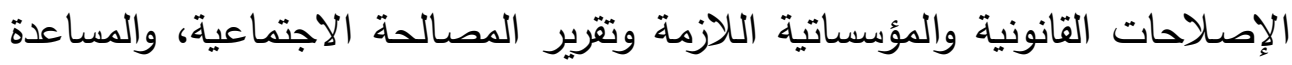

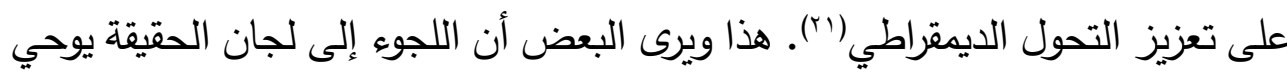
بأن الدولة أو بالأحرى نظام الحكم القائم غير جاد في تحقيق العدالة بقدر ما يحاول اعطاء صورة بأنه يرغب في تحقيقها، بدل أن يحاول إحداث تغيير حقيقي في الدولة

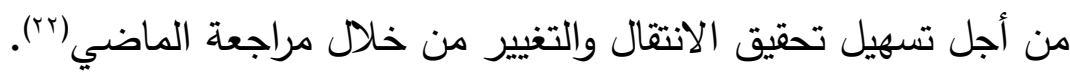
المطلب الثاني: المصالحة الوطنية بوصفها منطلق لتقييا مبدأ عدم الإفلات من العقاب وآليات تطبيقها

إن أول المسائل التي يجب العمل عليها في المرحلة الجديدة وإبان فترة العدالة الانتقالية مسألة ردم الهوة بين فئات المجتمع والعمل على إعادة ترميم أواصر العلاقة

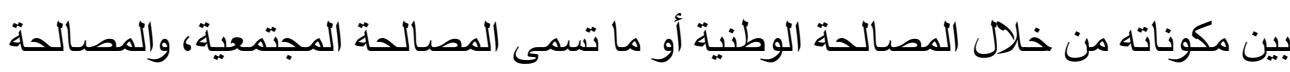

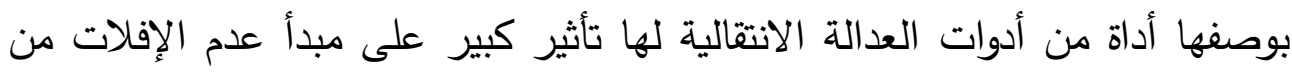
العقاب من خلال ما تضعه من تقييد على تطبيق المبدأ، لذا سوف نتتاول تدابير

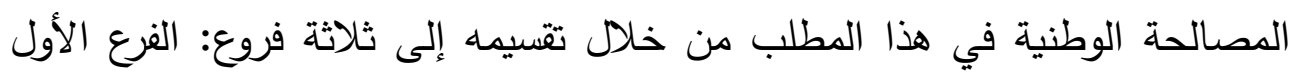
نتتاول فيه تعريف المصالحة الوطنية وآليات تطبيقها، وفي الفرع الثاني سوف نتناول

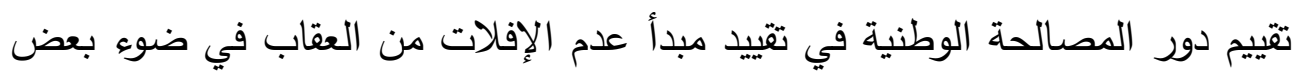


التجارب الدولية، أما الفرع الثالث فسيدرس تقييم دور المصالحة الوطنية في تقييد مبدأ

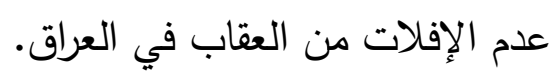

الفرع الأول: تعريف المصالحة الوطنية وآليات تطبيقها

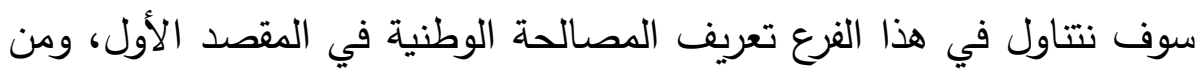

ثم سوف نبين آليات المصالحة الوطنية في المقصد الثاني وكالآتي: المقصد الأول: تعريف المصالحة الوطنية

المصالحة الوطنية أو المجتمعية تعبير كان أول من ردده شارل ديغول بمناسبة الونية

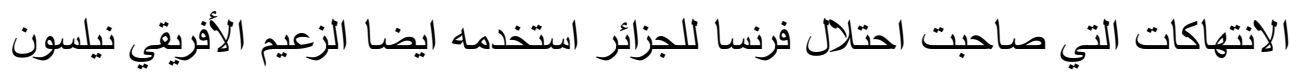

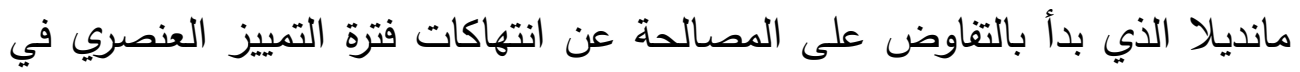

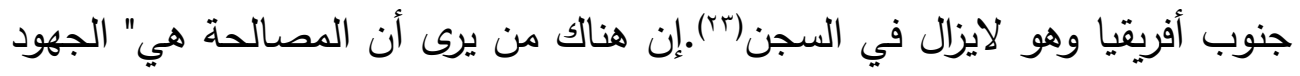

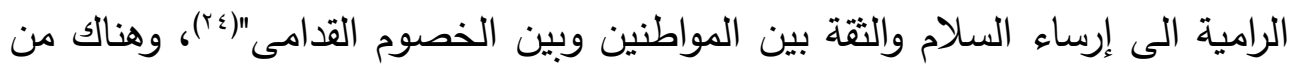

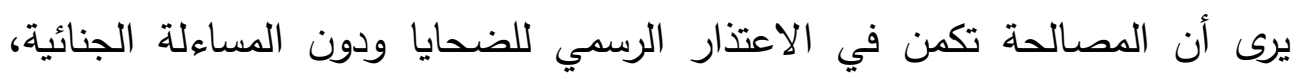

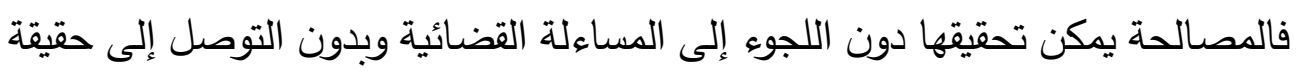

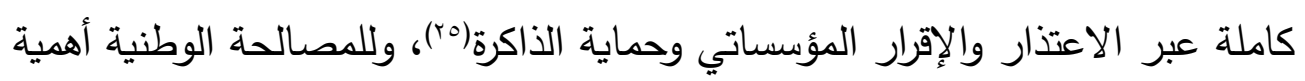

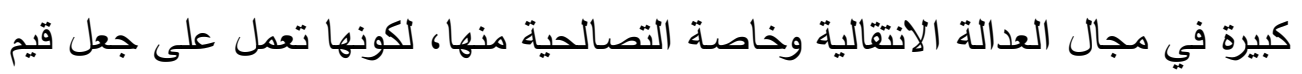

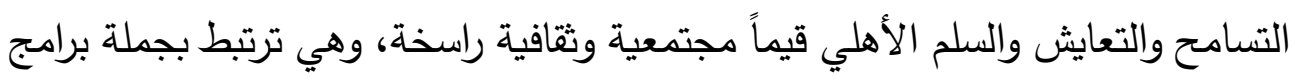

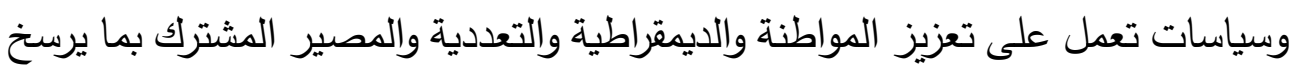

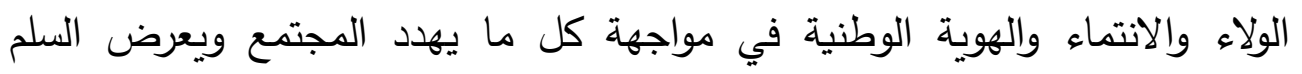

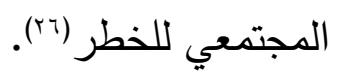

ترتكز المصالحة على تحديد الخطوات الأولى لتظيم انتقال السلطة بثكل

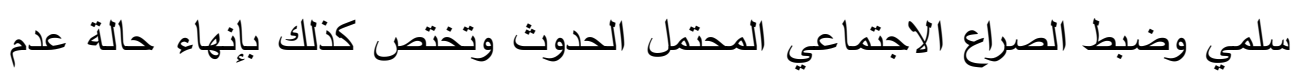

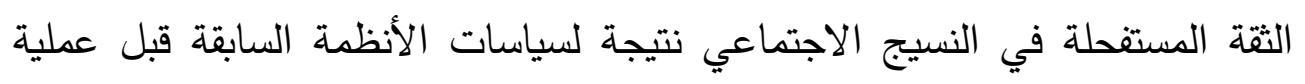

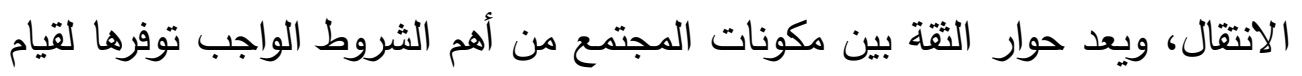

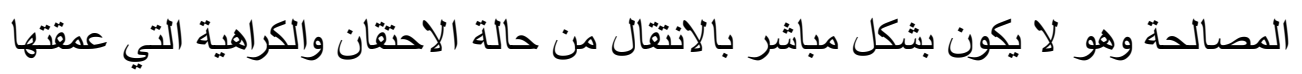

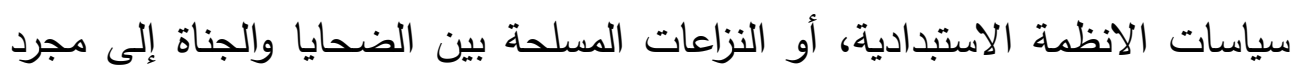




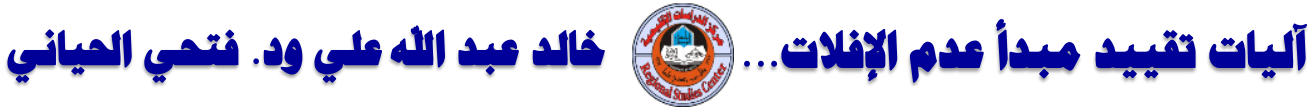

العفو والتصالح بل يحتاج إلى نشاط شامل تضطلع به السلطة الانتقالية(YY)، بحيث تبتعد عملية تحقيق العدالة التصالحية عن الثأر والانتقام وإلا فإنها لن تحقق النجاح وارساء السلام المستدام، فكلما اقتربت العدالة التصالحية من تمكين المجتمع من تمثيل روح المسامحة والمصالحة سهل ذلك عملية الانتقال التدريجي إلى حالة من الاستقرار والسلم

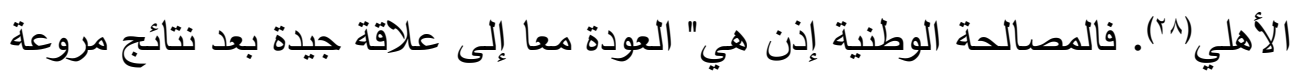

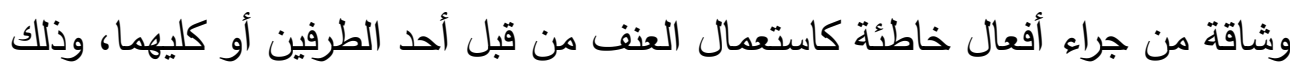

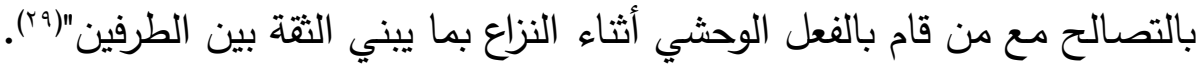
بينما عرفها الفقيه هودن بقوله: "المصالحة الوطنية تعني إعادة التواصل بين

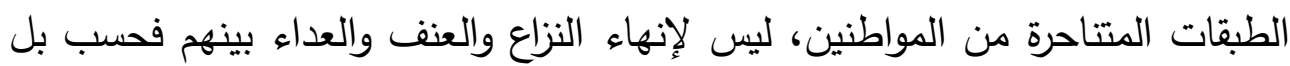

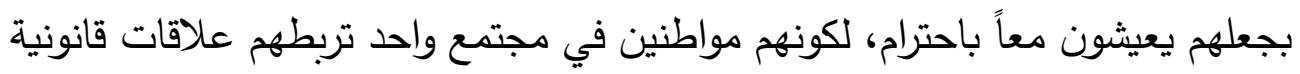

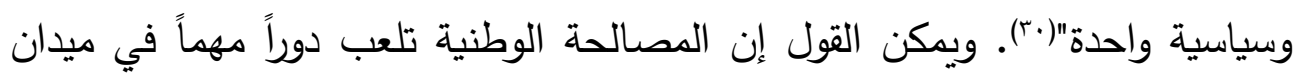
العدالة الانتقالية عموماً إذ تنهي حالة التناحر وتحفز على نبذ الخلاف، وتحد من حالة التحان اللاإستقرار في المجتمع، كما تقلي بأثارها على مبدأ عدم الإفلات من العقاب خصوصاً، وتعمل على الحد من فعاليته وتقييده.

\section{المقصد الثاني: آليات تطبيق المصالحة الوطنية}

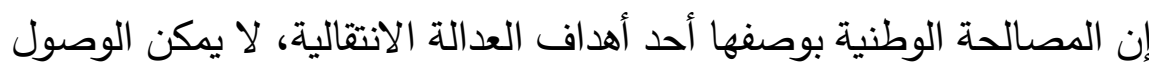

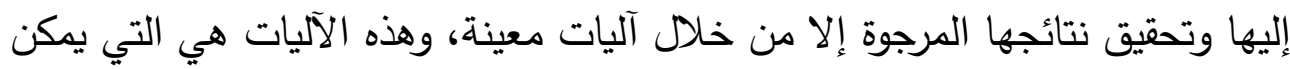
عن طريقها قياس مدى نجاح المصالحة من عدمه، وكذلك تبيان مدى قبولها في المجتمعات التي شهدت انتهاكات وجرائم مروعة في ظل الحكم السابق على عملية التحول الديمقراطي أو جراء نزاعات مسلحة عنيفة. وتتمثل هذه الآليات في الاتتصاف، وجبر الضرر، ورد الحق المادي والمعنوي على حدٍ سواء، وبصورة متساوية وفعالة

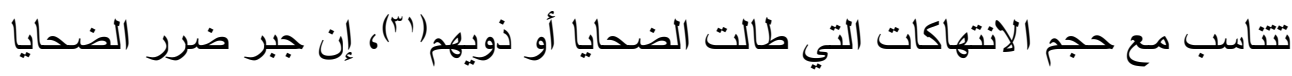

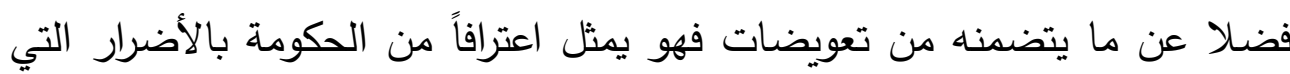

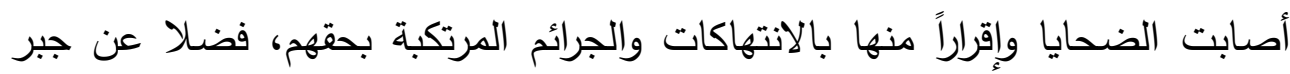

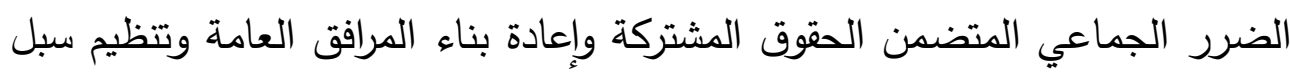




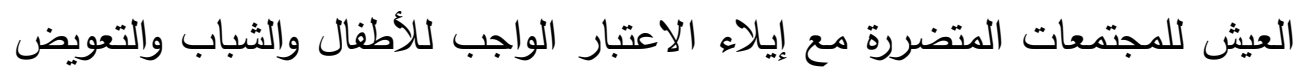

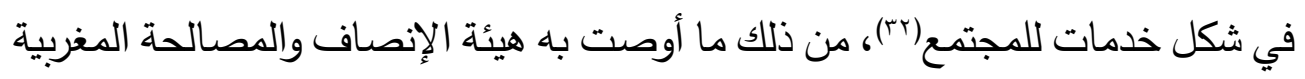

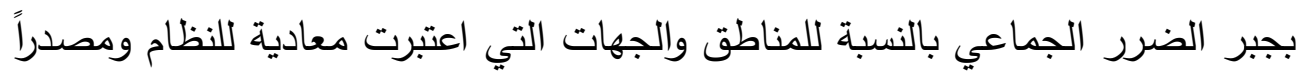

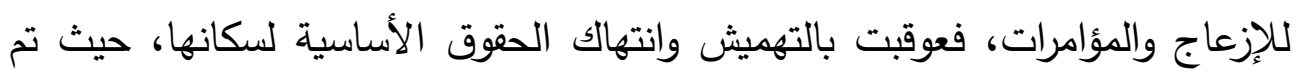

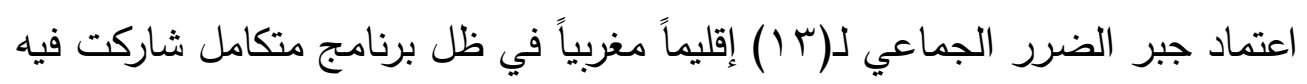

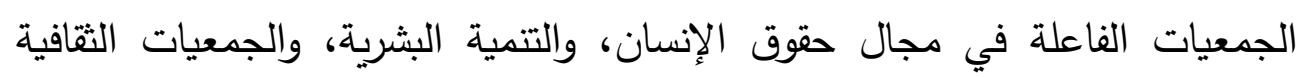

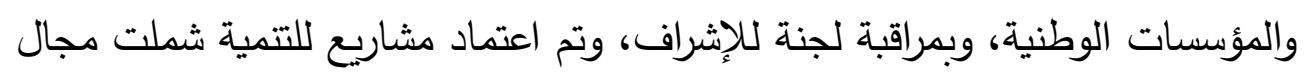

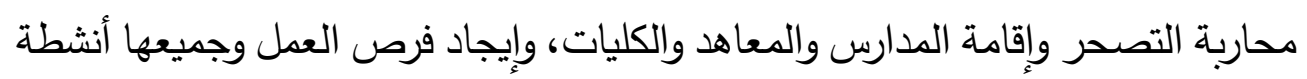

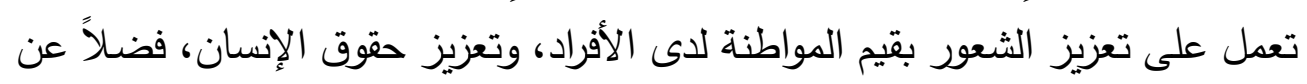

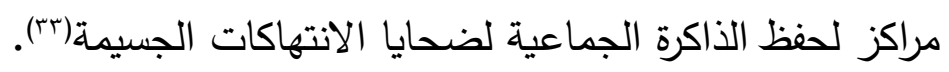

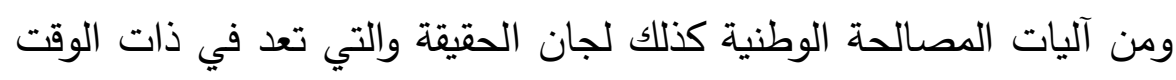

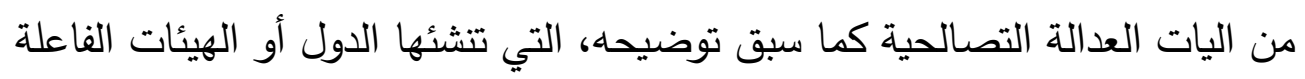

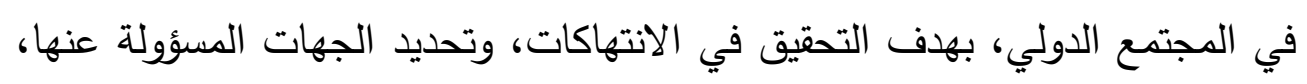

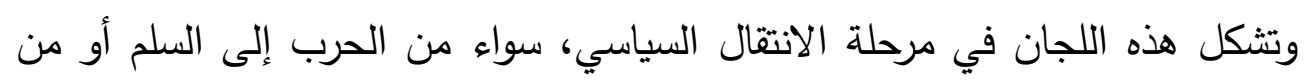

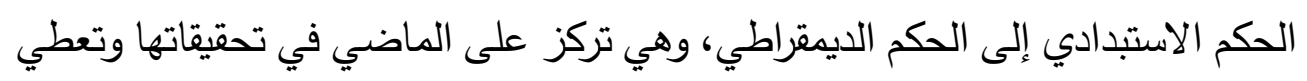

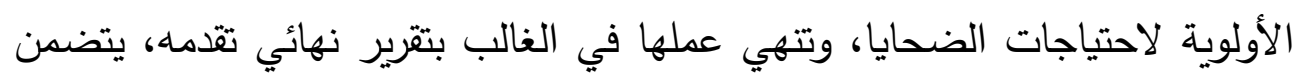

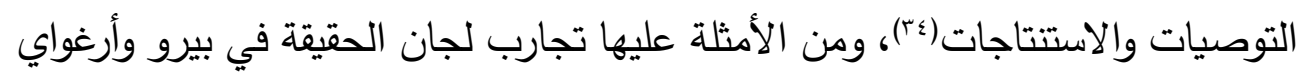

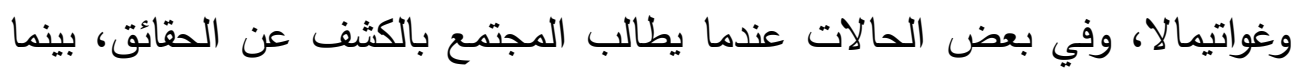

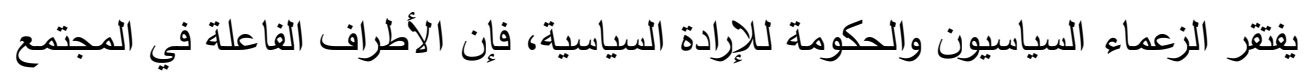

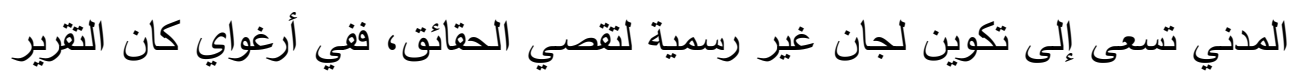

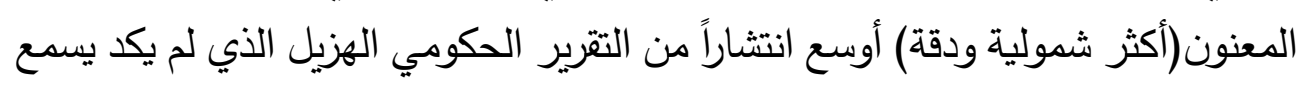

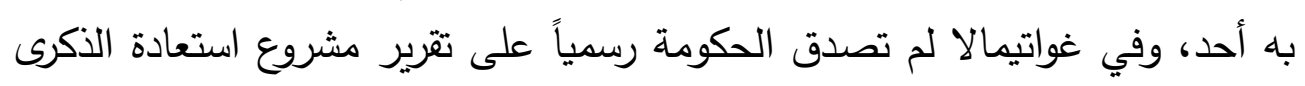

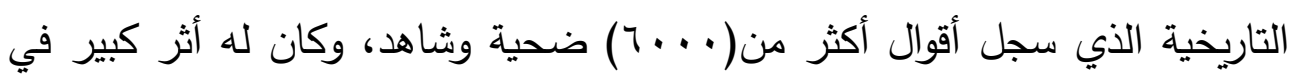

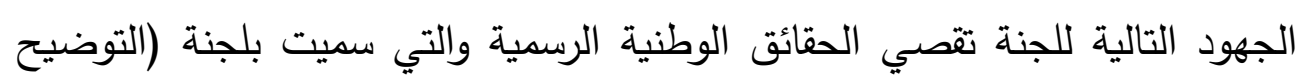
التاريخي)(ror)، كما أن للضحية والجاني الدور الأكبر في تحقيق الدصالحة الوطنية الجئية 


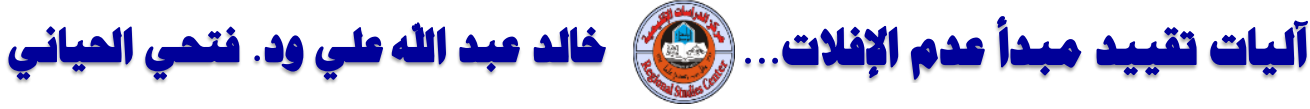

وبرعاية الدولة ومشاركتها، عندما يتم الجنوح إلى السلم والعفو والمسامحة والأخذ بمبدأ عفا الله عما سلف، والتسامح هنا هو التسامح الطوعي من الضحية، وبالمقابل فإن الاعتراف بالخطأ من جانب الجاني، وتحمله المسؤولية وطلب العفو، سيكون له أثره

الإيجابي على العلاقة بين الجانبين وعلى تحقيق المصالحة بين المجتمع(بَ). الفرع الثاني: تقييم دور المصالحة الوطنية في تقييد مبدأ عدم الإفلات من العقاب

$$
\text { في ضوء بعض التجارب الدولية }
$$

غالباً ما تتعارض المصالحة الوطنية مع العدالة الجزائية، وتمثل قيداً مفروضاً على مبدأ عدم الإفلات من العقاب، لكون مفهوم المصالحة الوطنية يقوم على مبدأ أساسي مفاده: أن المطالبة بالعدالة الجزائية ليست أمراً مطلقاً بحيث لا يمكن تجاوزه والخروج عليه، وإنما يجب أن تتم الموازنة بين تحقيق العدالة الجزائية، ومحاسبة مرتكبي الانتهاكات، وبين تحقيق السلم والديمقراطية والتتمية واستقرار أوضاع المجتمع(rY)، ويمكننا من خلال الاطلاع على التجارب الدولية بشأن المصالحة الوطنية أن نتبين

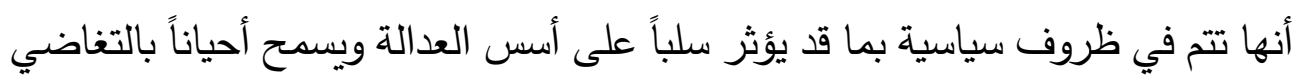
عن الانتهاكات الجسيمة لحقوق الإنسان، أو العفو عنها عفواً غير مشروط، وهو ما لقي معارضة من المنظمات الحقوقية والدولية وعلى رأسها الأمم المتحدة، إذ أن من شأن ذلك تكريس سياسة الإفلات من العقاب(^^). إلا أنه من الناحية الواقعية فإن عملية التحول من النظام الاستبدادي إلى نظام ديمقراطي يراعي حقوق الإنسان ويحترمها تتميز بتحديات كبيرة تؤدي في الكثير من الحالات إلى اضطرار الحكومات الانتقالية إلى الاختيار بين العدالة الجزائية والاستقرار والمحاسبة وتقديم مرتكبي الجرائم إلى المحاكم وبين استتباب السلم والأمن المجتمعي بالجنوح إلى المصالحة والتغاضي عن جرائم الماضي مع التعويض العادل والمنصف للضحايا بما يؤمن لهم جبر الضرر الذي لحق بهم. 
فالمصالحة تفترض العمل من أجل الوصول إلى حالة من السلم والاستقرار،

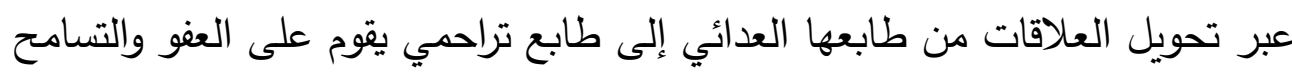

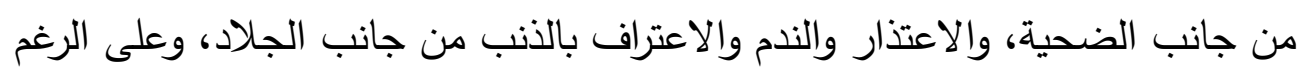

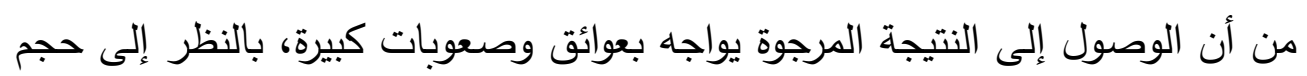
التراكمات الطويلة من الكراهية والحقد والعداء الناجمة عن الانتهاكات، والعمل عليها

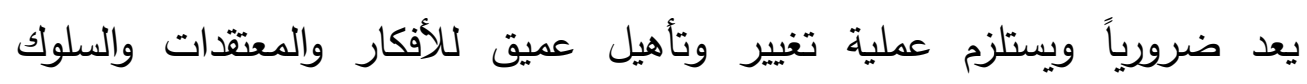

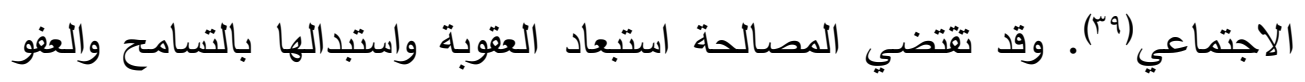

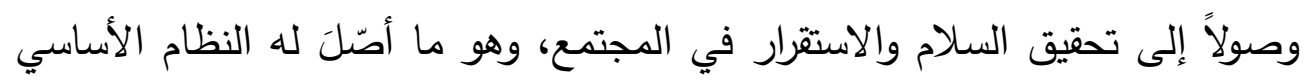

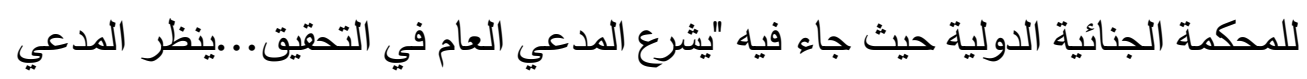

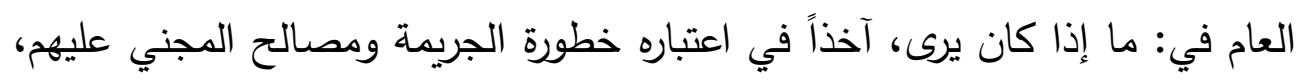

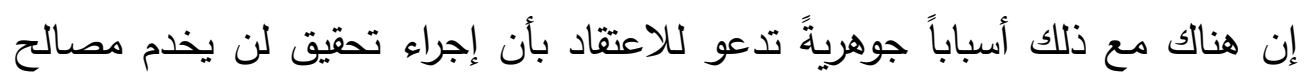

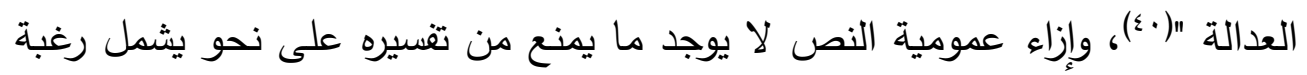

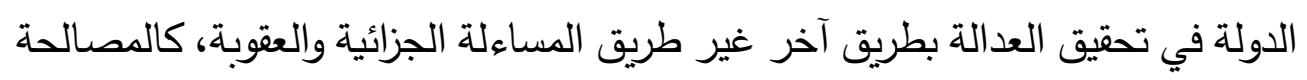

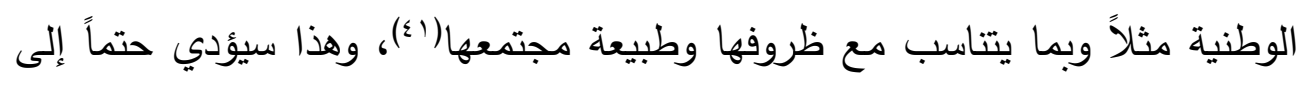

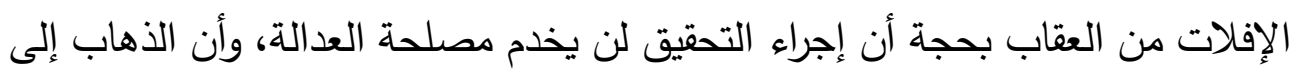

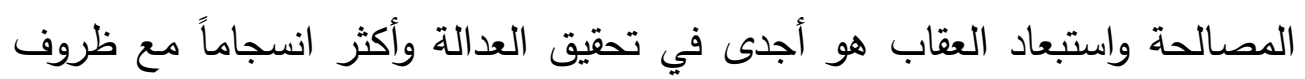

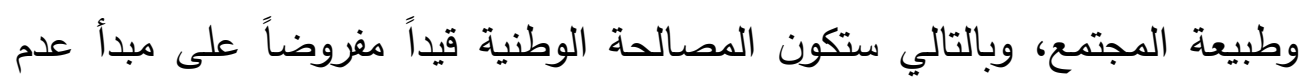

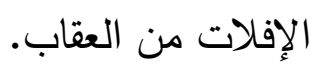

ونجد من خلال تجارب العدالة الانتقالية في العديد من البلدان أن المصالحة

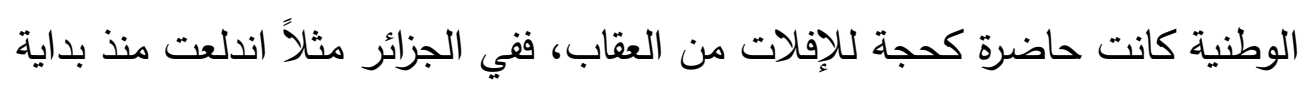

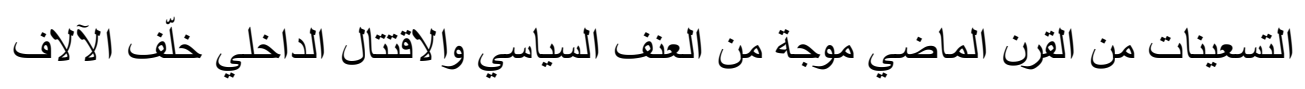

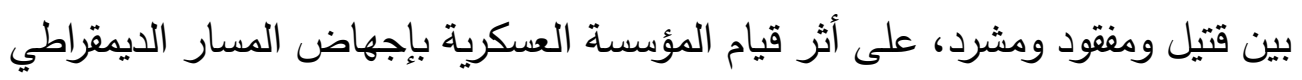




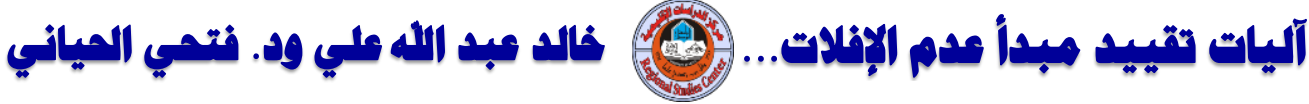

عام ب99 (9) وإزاء العنف المستشري تعددت محاولات الحكومة لتدارك الوضع، وتصميم المسار والوصول إلى مصالحة وطنية تضع حداً للعنف، وتوجت تلك المحاولات عام o . . ب بإصدار القانون المسمى ميثاق السلم والمصالحة الذي جوبه بالكثير من الانتقاد على المستوى الدولي والإقليمي، لكون القانون كان بمثابة المساومة على أمن الشعب الجزائري الذي أنهكته الحروب الأهلية، فضلاً عن مخالفته لمعايير القانون الدولي الإنساني، لكونه يقوض مبدأ عدم الإفلات من العقاب، ويحول دون كثف الحقيقة، كما أنه يمنع الأفراد والسلطة القضائية من فتح أية تحقيقات ضد الجهات الأمنية المختلفة، فكان من شأنه تكريس الإفلات من العقاب لمن دافعوا عن النظام سواء بحسن أو بسوء نية) أما في السلفادور فنجد أنه بعد (Y) (Iاماً من الحرب الأهلية التي شهدت أفظع الانتهاكات والخراب والدمار والمجازر المروعة التي وقعت على يد القوات المسلحة

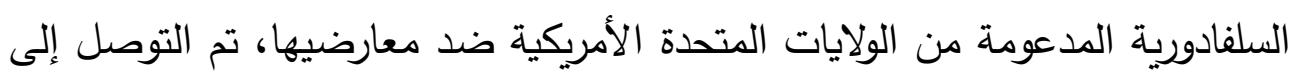
اتفاق سلام بين الحكومة والمعارضة، وتم توقيع اتفاقية (تثابو لتيبيك) سنة سو9 19 والذي تمت الموافقة عليه بعد خمسة أيام فقط من إصدار لجنة الحقيقة المدعومة من الأمم المتحدة تقريرها حول انتهاكات حقوق الإنسان الواسعة أثناء النزاع، إذ سمح هذا القانون لمرتكبي الانتهاكات وغيرها من المجازر بالإفلات من العقاب("^ء). ويمكن القول إن المصالحة الوطنية كونها تمثل قيداً على مبدأ عدم الإفلات من العقاب من عدمه، يعتمد أساساً على وجود الإرادة السياسية لدى النظام القائم في جديته بتقديم المجرمين إلى العدالة من عدمه، كما أن نمط التحول أو التغيير السياسي ومدى إسهام أدوات النظام السابق وما يملكه من التأثير على مسار العملية الانتقالية، فقد يكون النظام الجديد مضطراً إلى سلوك سبيل المصالحة والتغاضي عن الانتهاكات من أجل الحفاظ على الاستقرار والسلم المجتمي مع العمل على منح التعويضات وجبر الضرر للضحايا. 


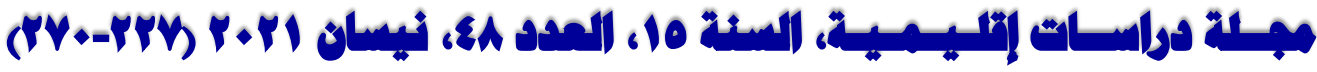

الفرع الثالث: تقييم دور المصالحة الوطنية وإجراء اتها في العراق تصاق تعد المصالحة الوطنية خياراً لابد منه لتجاوز مرحلة الماضي والشروع في عملية

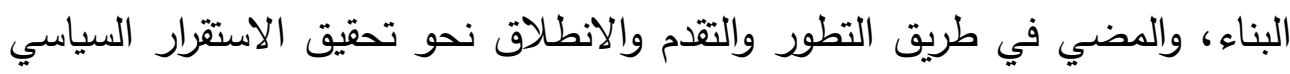
للوصول إلى مستقبل أكثر إثراقاً في البلدان التي مرت بحروب أهلية، وانتقلت من نظام استبدادي إلى نظام ديمقراطي، ولكل دولة تجربتها التي تتناسب مع ظروفها إنى الخاصة في مسألة المصالحة الوطنية، مع وجود قواسم ومشتركات أساسية بين جميع تجارب المصالحة في مختلف البلدان، تسهم تلك المشتركات في تغذية التجارب الوليدة حالياً

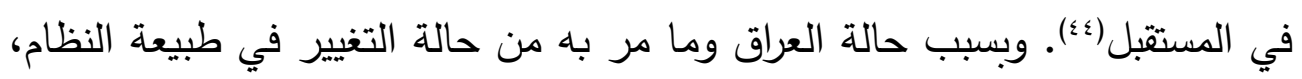
من نظام الحزب الواحد إلى نظام التعددية الديمقراطية، فهو بأثد الحاجة الى تحقيق

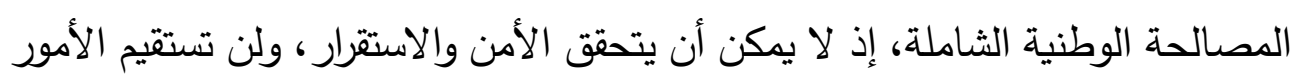
من دون المصالحة المشروطة بكونها مصالحة حقيقية وواقعية(0؛). لقد ثبت تاريخياً أن التعايش السلمي وكيفية إثاعته فعلياً في مرحلة ما بعد الصراع بين الفئات المتنازعة داخل الدولة الواحدة يحتاج إلى عمل طويل وشاق جداً، إذ إن الصراعات والانتهاكات الجسيمة لحقوق الإنسان يتولد عنها آثار ونتائج سلبية تؤثر بشكل كبير على معرفة المدة التي يمكن خلالها تحقيق التعايش السلمي بين تلك

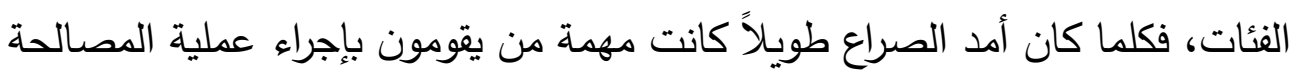
أكثر تعقيداً(؟). لقد نادى العراق بالسير على طريق المصالحة الوطنية، ولكن إرادة

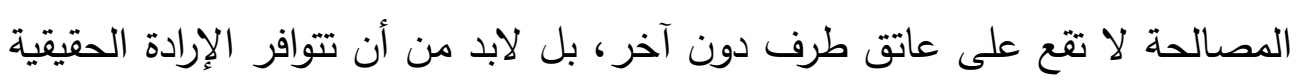

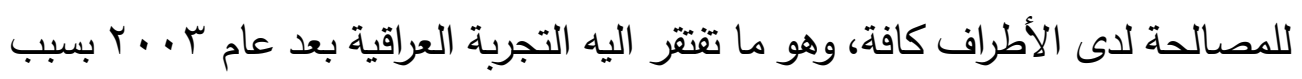

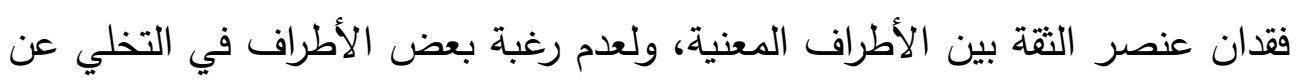

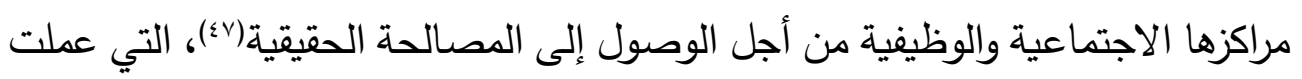
بشكل مباشر أو غير مباشر في سبيل تحقيقها مجموعة من المؤسسات في مقدمتها

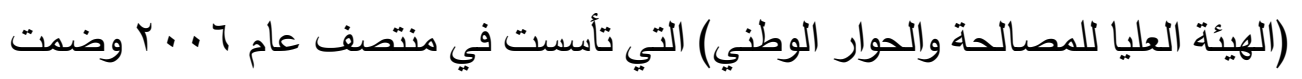
شخصيات تمثل جميع مؤسسات البلد، بما فيها المجتمع المدني والجامعات والفعاليات 


\section{خالد مبد الاله علي ود. فتمي المياني}

العشائرية، وقامت بوضع الأسس الاستراتيجية التي تقوم عليها المصالحة الوطنية، كما تثكلت إلى جانب ذلك عدد من المؤسسات التي يؤدي عملها بشكل مباشر أو غير مباشر إلى دفع عجلة المصالحة إلى الأمام، وهذه المؤسسات تجد أساسها القانوني في الدستور العراقي عام ه . . ب وتمت الإشارة إليها في الباب الثاني تحت عنوان الأحكام

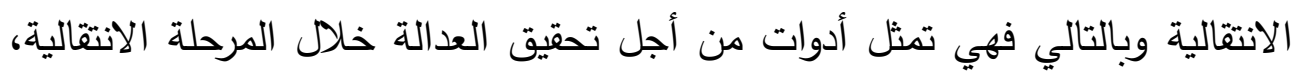

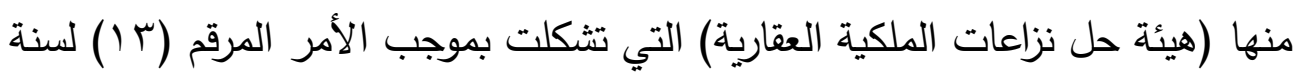

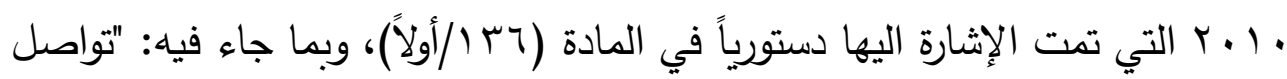
هيئة دعاوى الملكية عملها بوصفها هيئة مستقلة بالتتسيق مع السلطة القضائية والأجهزة التنفيذية وفقاً للقانون، وترتبط بمجلس النواب"، وهذه الهيئة... يرتبط عملها بدعم

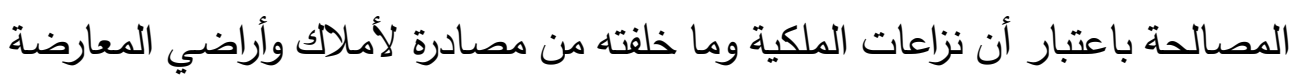
أو إعطاء أو بيع تلك الأملاك للغير تعد من المشكلات التي تسهم في إعاقة عملية المصالحة الوطنية، فكان تثكيل تلك الهيئة وقيامها بحل غالبية تلك المنازعات العقارية سواء بالرد أو التعويض، إسهاماً إيجابياً في مسار المصالحة الوطنية، إلى جانب ذلك

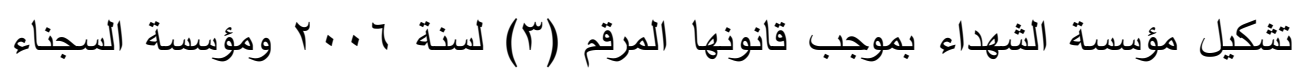
السياسيين بموجب قانونها المرقم (ع) لسنة ج . . † ، وهاتان المؤسستان، قد وردت الإشارة إليهما دستورياً في المادة (بr /أولاً)، بالقول: "تكفل الدولة رعاية ذوي الثهداء والسجناء

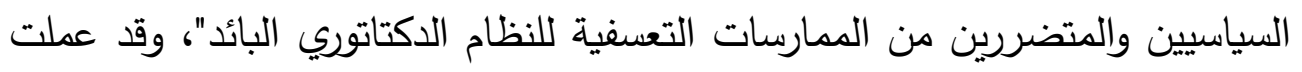
تلك المؤسسات على جبر الضرر للضحايا، وإشعارهم بالانتصاف لهم، وخلق شعور بعدم وجود خاسر في المصالحة الوطنية(^^). أن الجزء الأهم في سبيل تحقيق المصالحة يقع على عاتق اللجنة العليا

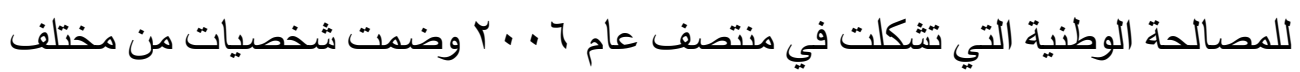
مكونات المجتمع العراقي، وتهدف إلى إعداد لقاءات دولية لتطوير التجربة الديمقراطية الجديدة في العراق والعمل على استيعاب القوى المعارضة واعتماد الآليات السلمية للحوار وتسوية الأزمات مثل عقد مؤتمرات محلية في الموصل وأربيل والناصرية، ومؤتمرات وليدي 


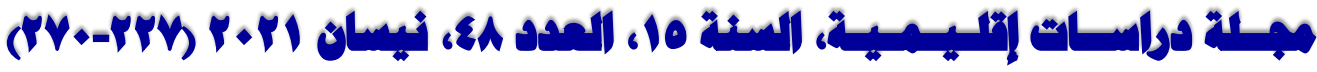

دولية مثل مؤتمر هلنسكي، مع زيارة وفود عراقية إلى إيرلندا للاستفادة من تجربتها في

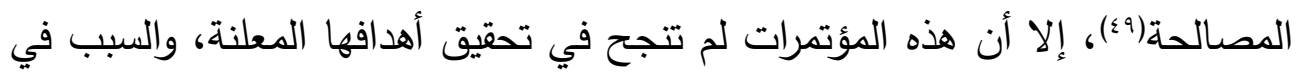
ذلك يعود إلى عدم جدية الأطراف القائمة على تنظيمها، وعدم وجود الإرادة السياسية لذلك، فضلا عن وجود عوائق حقيقية منها دستورية تتطلب مشاركة الجميع في تجاوزها عن طريق تعديلات دستورية تتاسب موضوع المصالحة، وعلى رأس تلك التعديلات

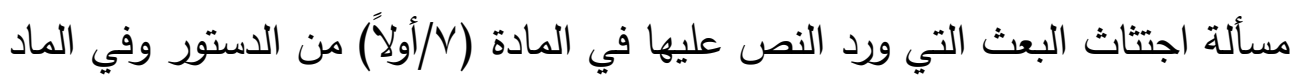

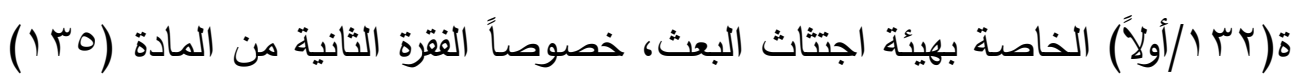
التي نصت على جواز قيام مجلس النواب إنهاء عمل الهيئة، وإسدال الستار على مسألة الاجتثاث، وبالتالي دعم المصالحة، وعدم الإجماع من جانب الأطراف المعنية على في أهمية المصالحة، وكذلك عدم وجود رؤية موحدة لها لاى كل الأطراف مما يجعلها بحاجة إلى رؤية شاملة لحل المشكلات التي افرزتها العملية السياسية(•). وفي أطار تقييم دور وإجراءات المصالحة الوطنية في العراق يمكن القول إن ما ميز المشهد العراقي بعد عام r . .r وجود ثلاثة مستويات للحوار والمصالحة الوطنية مختلفة في درجة الإقبال عليها من القوى الفاعلة والمعنية بالعمل من أجل تحقيقها، وتتمثل هذه المستويات في:

أ-الحوار والمصالحة بين الأطراف الفاعلة في العملية السياسية (الحكومة والمعارضة داخل العملية السياسية). ب-الحوار والمصالحة مع أطراف العملية السياسية الحكومة والمعارضة من جهة، والأطراف المعارضة الأخرى خارج العملية السياسية من جهة أخرى.

ج - الحوار بين القوى السياسية والمجتمع أو ما يمكن تسميته بالحوار الوطني( (ه).

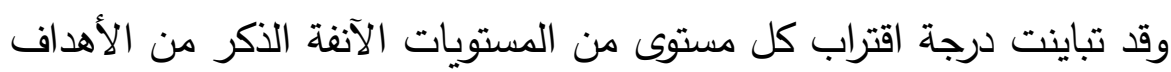

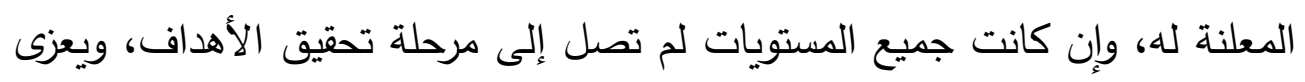
هذا الفشل إلى أن المصالحة الوطنية تحتاج إلى الاعتراف بالآخر ، سواء على مستوى الصى

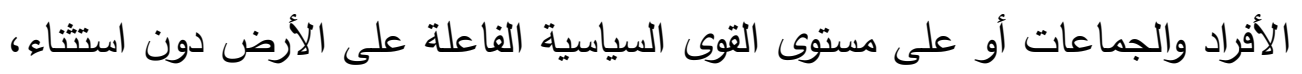




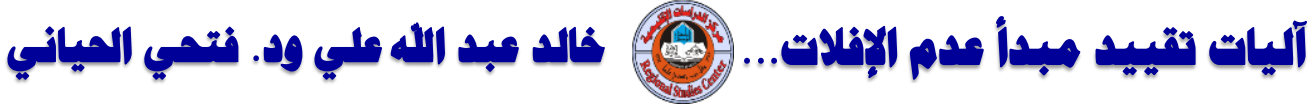

فالاعتراف بالآخر هو الركيزة الأساسية لأي حوار، فلابد للجميع من الجلوس على

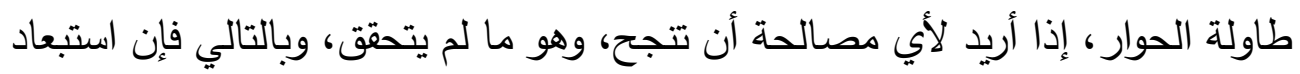

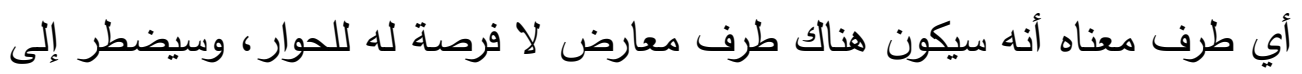
سلوك سبيل العنف، فيكون هناك عنف وعنف مضاد، ومن ثم إضعاف الأمن الداخلي للبلاد والذي يعود بنتائج سلبية على الدولة كياناً وشعباً وحكومة بإضعافها وتعريضها للتنخلات الخارجية- وهو ما حدث في الساحة العراقية- لتحقيق الأهداف الخاصة ونها

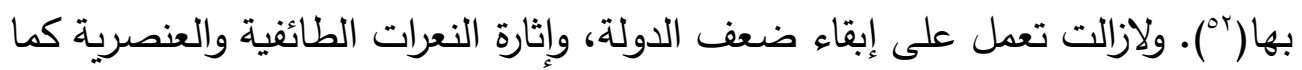
أن تغليب البعض المصالح الفئوية والثخصية على المصالح العليا للمجتمع، فضلاً عن غياب الحد الأدنى من الاتفاق بين القوى السياسية نفسها، وأيضاً انتشار الفساد بكل أشكاله ومستوياته في مؤسسات الدولة العراقية، والافتقار إلى الجدية في تبني

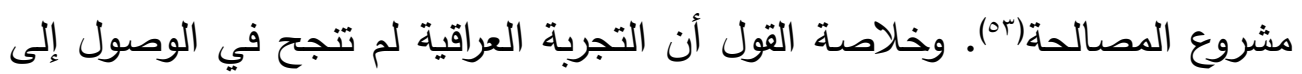

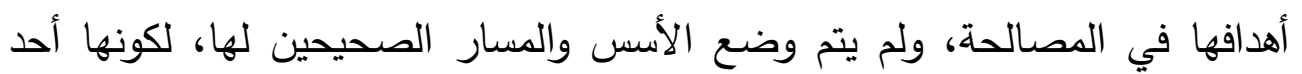
العناصر الفعالة في مسيرة العدالة الانتقالية(؛).

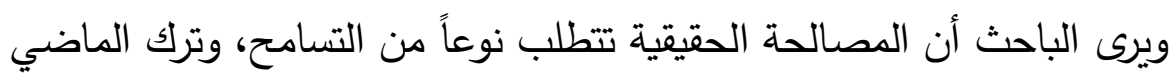

والعمل بمبدأ عفا الله عما سلف، والنظر إلى المستقبل، والعمل على إلغاء بعض القوانين التي تشكل عقبة حقيقية أمام المصالحة، والعمل الجاد على تفعيل الدستور وربما تعديل بعض احكامه التي لا تتسجم ومتطلبات المصالحة، وتوفر الإرادة الحقيقية من القوى

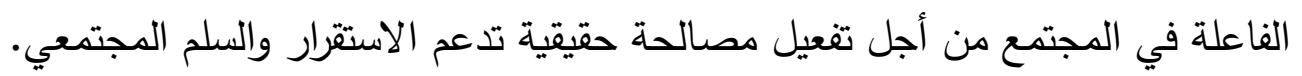




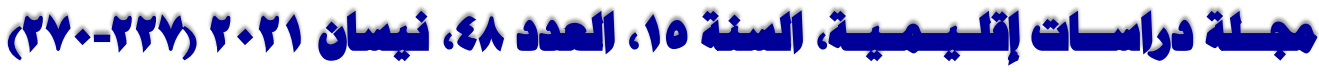

\section{المبحث الثاني}

\section{تدابيز العفو خلال فتزة العدالة الانتقالية}

يعد العفو من أقدم وأهم الأسباب التي يتم التذرع بها للإفلات من العقاب، وإسقاط الحق في محاسبة المجرمين، وصاحب الحق في ذلك هو الجماعة بأسرها، وتتوب عنها الدولة بما لها من سلطة وسيادة على الأفراد والجماعة، وبالتالي لم يعد المجني عليه هو صاحب الحق والكلمة الأخيرة في إسقاط العقاب بالعفو من عدمه، كما كان الأمر عليه في العصور القديمة، وإذا كان من يملك سلطة القرار في الدولة

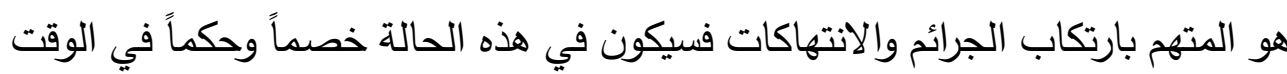
ذاته، وسوف يستعمل السلطة التي يملكها للإفلات من العقاب عما ارتكبه من جرائم ولا وسيلة أفضل من العفو للوصول إلى ذلك الإفلات. سنبحث في هذا المبحث تدابير

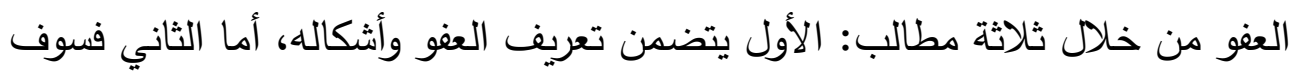
نبحث فيه عن الثرعية الوطنية والدولية لمنح العفو في فترة العدالة الانتقالية، المطلب الثالث، سنبين فيه دور تدابير العفو في تقييد مبدأ عدم الإفلات من العقاب خلال فترة فيه لتهرة العدالة الانتقالية.

المطلب الأول: تعريف العفو وأشكاله

سوف نتناول في هذا المطلب تعريف العفو في الفرع الأول، ومن ثم سنبين

$$
\text { أشكال العفو في الفرع الثاني: }
$$

تستخدم مفردة العفو للإشارة إلى تلك التدابير الصادرة عن السلطة والتي تؤدي إلى حظر الملاحقة الجنائية وأحياناً الإجراءات المدنية أيضاً ضد أشخاص معينين أو أو فئات معينة من الأشخاص، فيما يتعلق بسلوك إجرامي محدد ارتكب في مرحلة سابقة

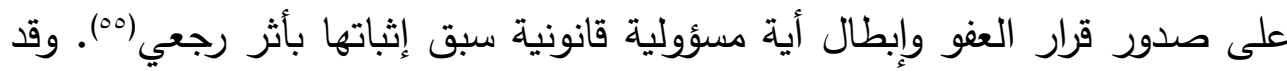
عرّف فقهاء القانون العفو بأنه" إنهاء التزام بتنغيذ عقوبة إزاء شخص صدر صدر ضديه ضده حكم 


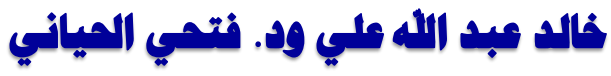

مبرم بها إنهاءً كلياً أو جزئياً واستبدال التزام آخر به، موضوعه عقوبة أخرى، وذلك بناءً

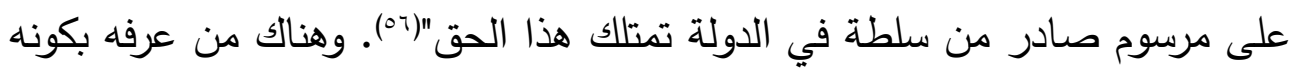
"حالة قانونية ناتجة عن إجراء قانوني داخلي أو دولي يعمل على محو الإدانات الجنائية المقررة، أو وضع استثناءات مؤقتة أو شخصية ضمن التشريع الجنائي تمنع من متابعة وإدانة أشخاص متهمين بارتكاب أفعال إجرامية، فالعفو يمحو الفعل المعاقب عليه بوقف

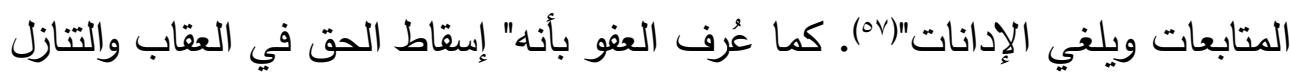
عنه سواء كان هذا التتازل كلياً أو جزئياً وإحلاله بعقوبة أخف، فالعفو عن الجريمة من بن إنهاب شأنه أن يزيل عن الفعل صفته الإجرامية فتمحى الجريمة ذاتها، ويعد الجاني كأنه لم

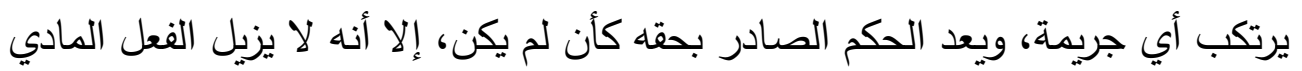
ذاته، وما ترتب عليه من آثار خارجة عن النطاق الجنائي"(^ه). ولا تتدرج في نطاق تدابير العفو تلك الإجراءات الأخرى المؤدية إلى الإفلات من العقاب، والتي لا ينطبق عليها تعريف العفو على الرغم من أنها تؤدي إلى نتائج مشابهة للعفو كامتتاع الدولة عن تشريع القوانين التي تحظر الأفعال التي تعد جرائم، أو امتناع الدول عن اتخاذ الإجراءات الجنائية بحق المسؤولين عن الانتهاكات على الرغم من أن القوانين لا تمنع اتخاذ الإجراءات بحقهم، أو امتتاع الدول عن إتاحة الموارد التي يحتاجها المدعي العام لضمان فعالية عمله لمقاضاة المتهمين وتخويف الشهود الذين لابد من شهاداتهم لضمان محاسبة قانونية كاملة للمتهمين(09). كما يختلف العفو عن الجريمة عن الصفح الذي هو العفو عن العقوبة بعد النطق بها، والصفح هو لرئيس الدولة يصدر بقرار منه،

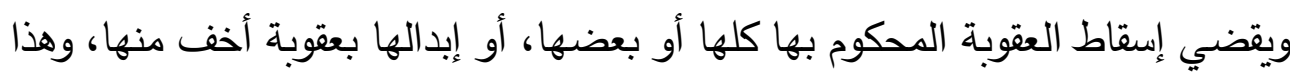
العفو لا يمحو عن الفعل صفته الجرمية، وإنما يقتصر فقط على إسقاط العقوبة المحكوم بها) (7.) 


\section{الفرع الثاني: أنواع العفو}

هناك مناهج عدة تتتهجها الدولة في الوصول إلى آلية العفو، ذلك أن هنآك الكي

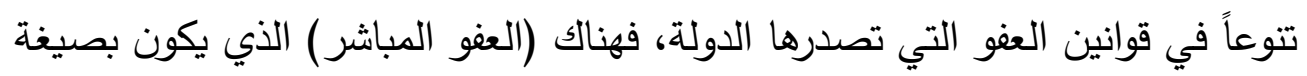

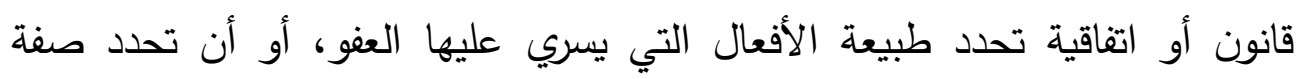

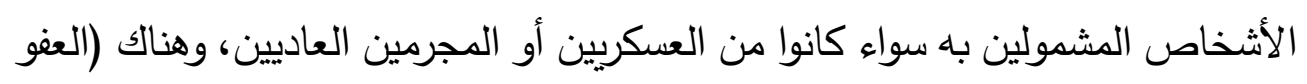

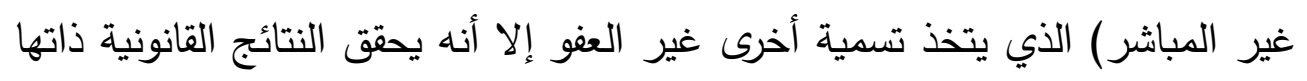

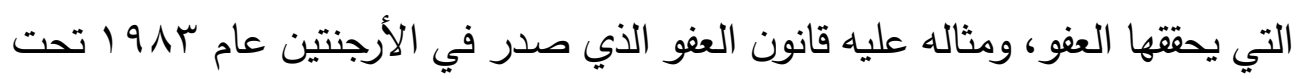

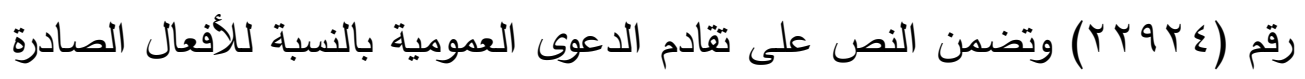

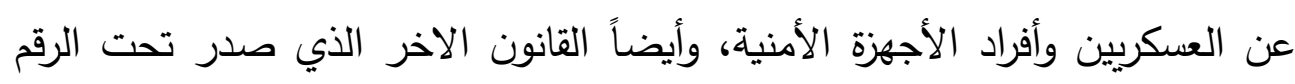

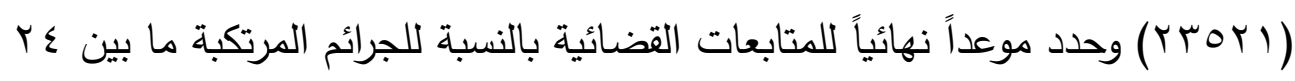

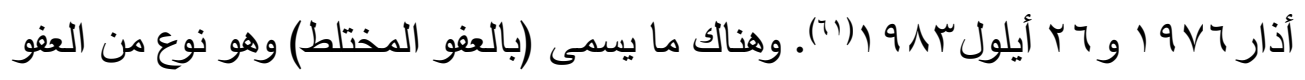

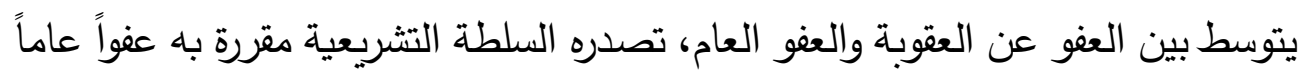

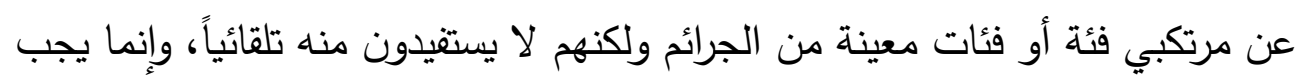

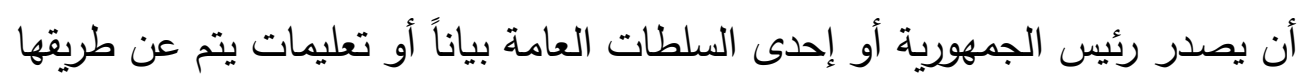
تعيين الفئات التي تتنفع بهذا العفو (Tr).

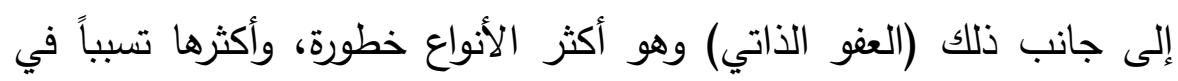

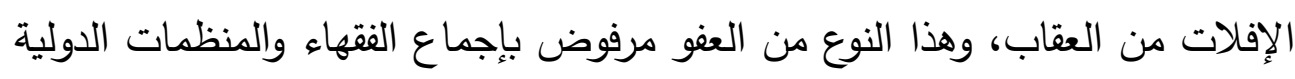

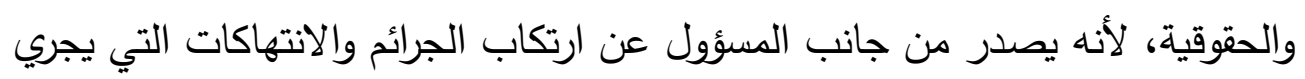

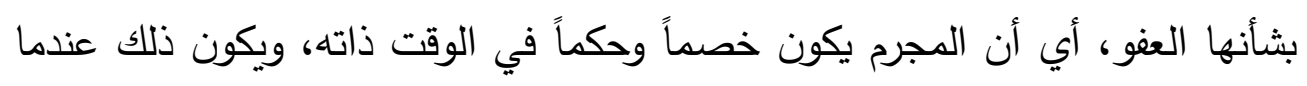

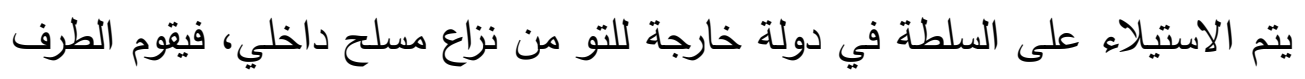

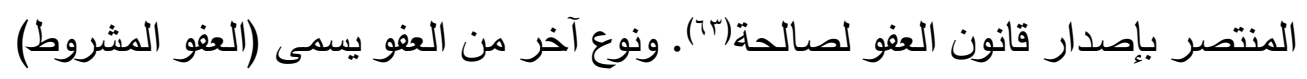

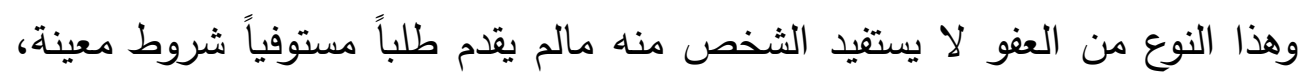

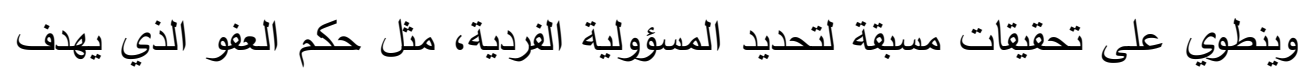

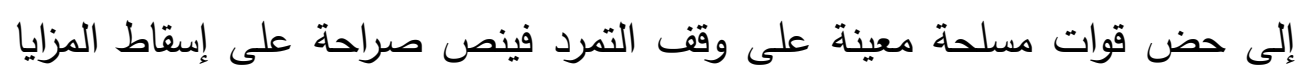




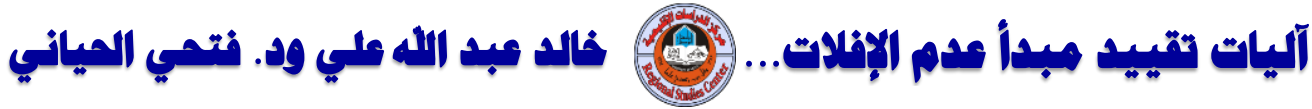

الممنوحة إذا عاد الطرف المستقيد إلى رفع السلاح(ء). والمثال الأوضـح على هذا الثكل

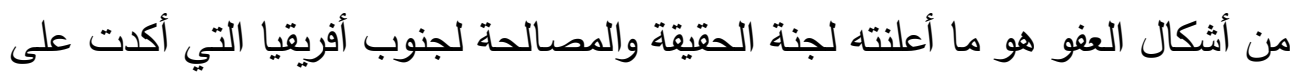
عملية العفو في هذا البلد والتي لها طابع فريد لأنها لم تتص على عفو شامل وانما على عفو مشروط، إذ اشترطت الكثف العلني عن الجرائم المتعلقة بانتهاكات حقوق الإنسان

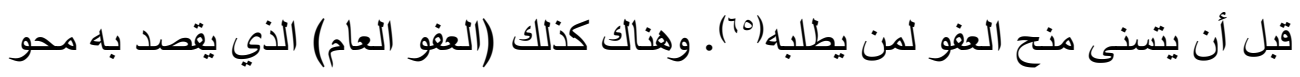
الصفة الجرمية عن الفعل المرتكب، بحيث لا يمكن رفع الدعوى ضد مرتكب الفعل، وإذا كانت الدعوى مرفوعة قبل صدور العفو فإنها تتقضي ويمحى الحكم الصادر من قبل العفو ضد المتهم(T1). أما (العفو الخاص)، فهو ذلك العفو الذي يصدر بقانون أو مرسوم في مناسبات معينة ويسمى بالعفو عن العقوبة، فهو لا يمحو الصفة الجرمية

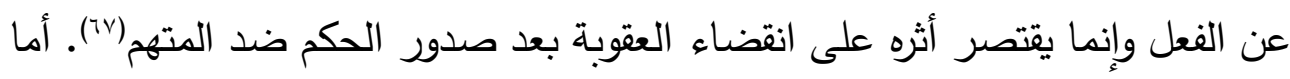
العفو الشامل فهو ذلك العفو الذي يصدر بقانون ينطبق على الجميع ويتصف بصفة العمومية دون اشتراط تقديم أي طلب من جانب المشمولين به، ولا يندرجون تحت نطاق تطبيقه أو عدم تطبيقه (1^).

ومن ناحية أخرى أن هناك بعض القوانين والأنظمة التي تصدرها الدول تشكل عفواً بحكم القانون، وعلى الرغم من ان هذه الأنظمة لا تسقط المقاضاة الجنائية أو سبل

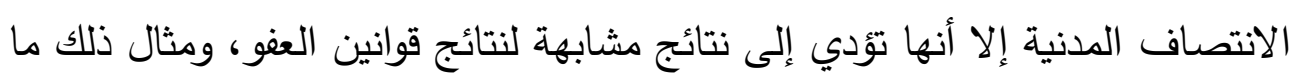
ذكرناه عن تجربة الأرجنتين بما يسمى (قانون نقطة النهاية)، الصادر عامج1919 الالذي

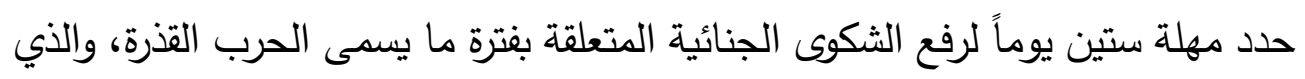

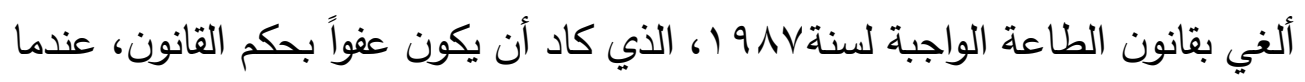

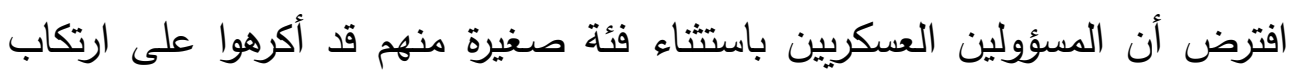
الانتهاكات، لذا وجب منحهم حصانة من المقاضاة على هذا الأساس(79). 


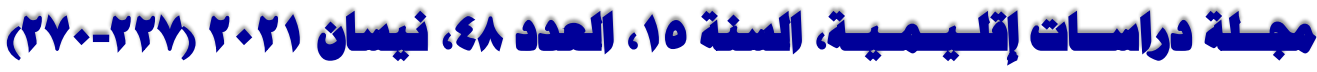

المطلب الثاني: شرعية منح العفو خلال فترة العدالة الانتقالية ودره في تقيد مبدأ عدم الإفلات من العقاب

تتطوي مسألة العفو خلال فترة العدالة الانتقالية على أشكال عدة كما بينا في الفرع السابق، نظراً لما تثكله من مساس بحقوق الضحايا، وحماية مرتكبي الجرائم والانتهاكات، والأمثلة كثيرة على ذلك، منها عفو العسكريين عن أنفسهم في شيلي والأرجنتين كإجراء يسبق التحول إلى الديمقراطية(v). وهنا يثار تساؤل حول مدى التى الثرعية الوطنية والدولية لمنح العفو خلال المرحلة الانتقالية للمتهمين بارتكاب الجرائم والانتهاكات ضد حقوق الإنسان، وهذا الأمر معني بالإطار القانوني الذي يحكم العفو

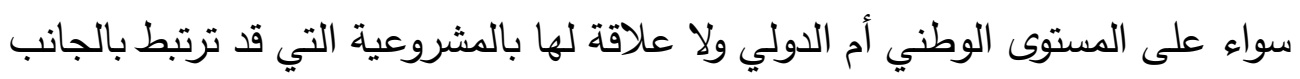
القيمي أكثر من الجانب النصي، ولهذا سوف نقسم هذا المطلب إلى فرعين، يدرس

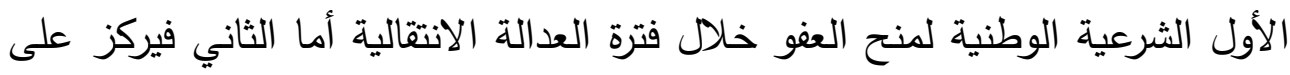
شرعيته الدولية وذلك من أجل معرفة الفرع الأول: الثرعية الوطنية لمنح العفو خلال فترة العدالة الانتقالية

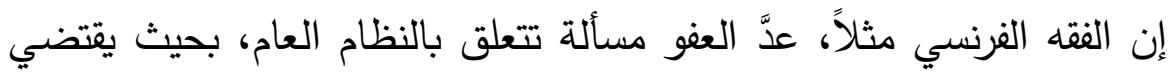

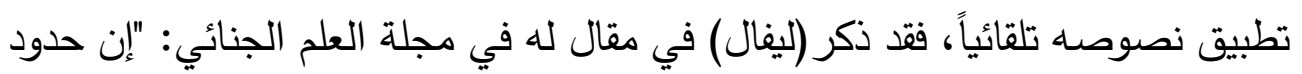
العفو هي الحدود التي يعطيها اياه القانون الذي يعلن هذا العفو"، ويرى الفقيه (باتستيني)

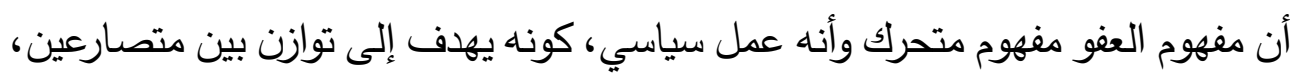
وتعادل بين متقاتلين لم يبقَ لهم للخروج من دائرة تصارعهم وتقاتلهم إلا التواصل والتسامح فيما بينهم(')(') وكان (مونتسكيو) من المتحمسين لفكرة العفو، وكان يرى أن: "العفو من أعظم الوسائل التي تتخذها السلطات المعتدلة في سبيل الضبط والربط لما في سلطة العفو من جلب للحكمة والدراية التي يمكن أن تأتي بنتائج جيدة جداً"(Vr). لقد انتشر اللجوء إلى العفو في الدول إذ وبحسب الدكتور شريف بسيوني فإن من بين

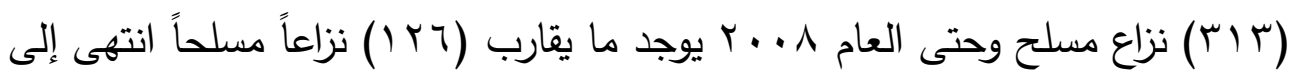

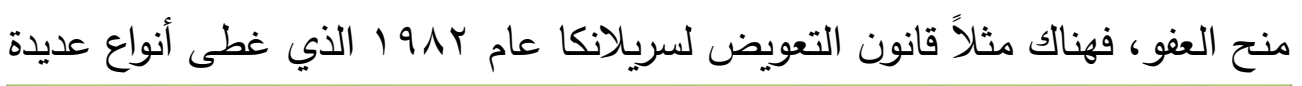




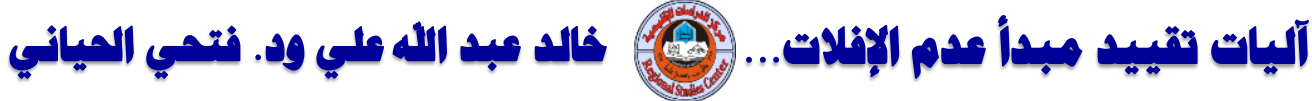

من الجرائم، ومرسوم تتفيذ حكم العفو الوارد في اتفاق واغادوغو لعام V . . ب في ساحل العاج(Vץ)، وأيضاً تجربة جنوب أفريقيا التي منحت الأفراد عفواً عن المقاضاة أمام المحاكم، وقانون النقطة النهائية عام 191 في الأرجنتين الذي حدد فترة لا تزيد عن ( ( ) يوم من تاريخ صدور القانون لتقديم الثكاوى الجنائية ضد الأشخاص خلال فترة ما تسمى بالحرب القذرة(1). وعلى صعيد الدساتير الوطنية، فلا يكاد يخلو دستور من النص على العفو

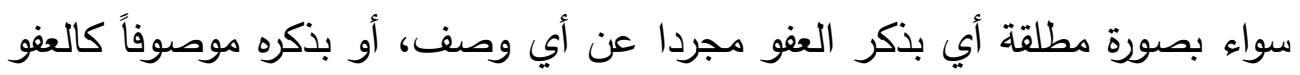

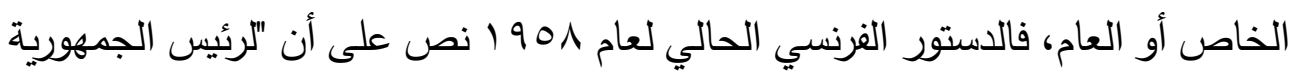

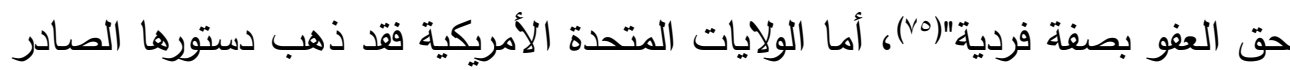
عام VA9 إلى صلاحية منح العفو للسلطة التنفيذية، ممثلة بالرئيس الأمريكي ولحكومات الولايات عدا بعض الاستثناءات التي أعطيت صلاحية إصدار العفو بشأنها إلى السلطة

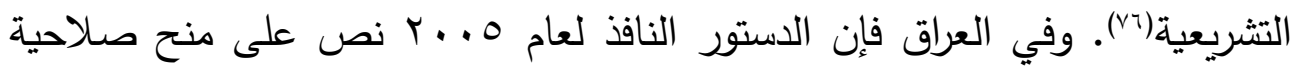
العفو الخاص لرئيس الجمهورية في مسائل معينة بناءً على توصية من رئيس مجلس الوزراء، واستثنى من ذلك ما يتعلق بالحق الخاص، والمحكومين بارتكاب الجرائم الدولية،

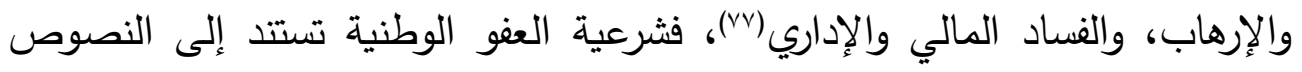
الدستورية التي تقرر منحه في حالات معينة، وإلى قوانين العفو الصادرة بخصوص تلك النصوص الاستورية.

الفرع الثاني: الثرعية الدولية لمنح العفو خلال فترة العدالة الانتقالية أن منح العفو أثناء فترة العدالة الانتقالية عن الجرائم السابقة يعد أمراً وارداً، وهو ما ييرر ورود النص عليه في المواثيق الدولية الخاصة بالنزاعات المسلحة الداخلية على

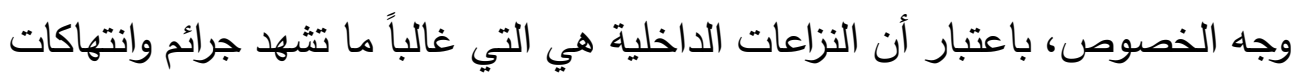
يجري الحديث عن العفو بشأنها خلال فترة العدالة الانتقالية. فقد أثار البرتوكول الإضافي الثاني لعام 19VV الملحق باتفاقيات جنيف الى أن "تسعى السلطات

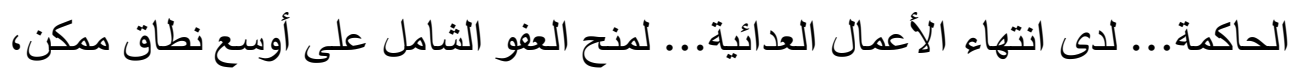


للأشخاص الذين شاركوا في النزاع المسلح أو الذين قيدت حريتهم لأسباب تتعلق بالنزاع

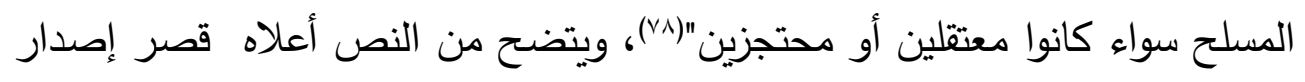

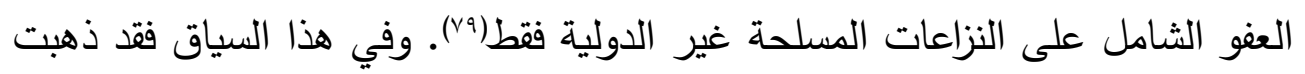

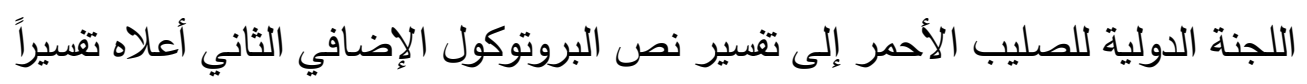

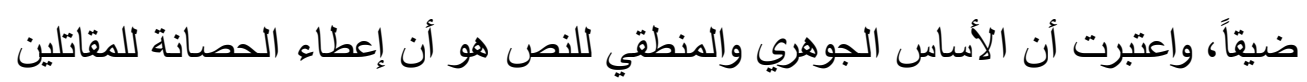

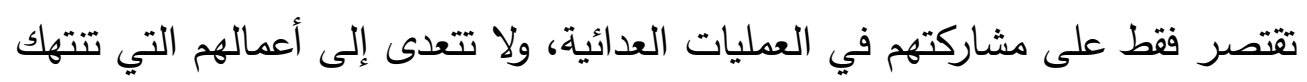

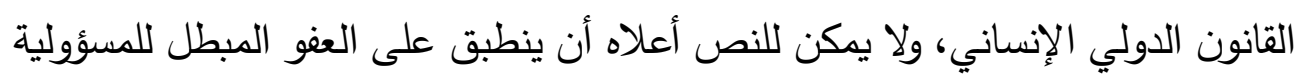

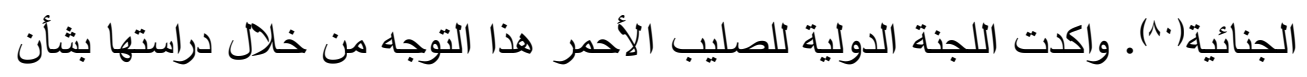

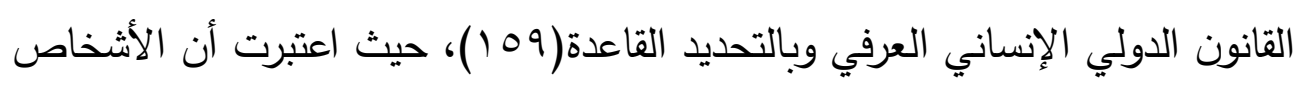

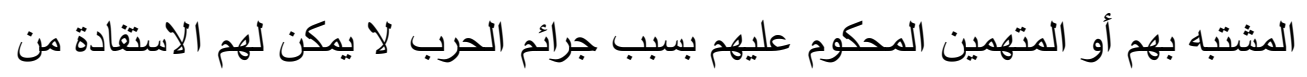

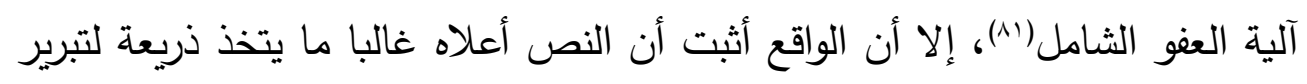

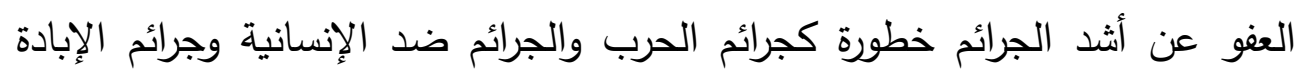

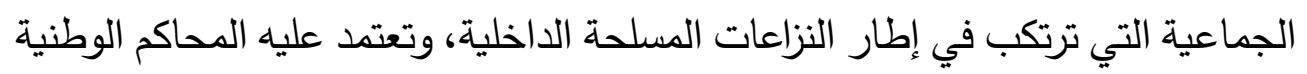

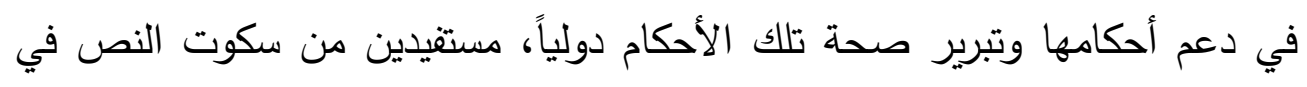

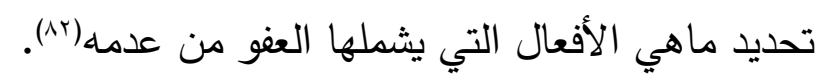

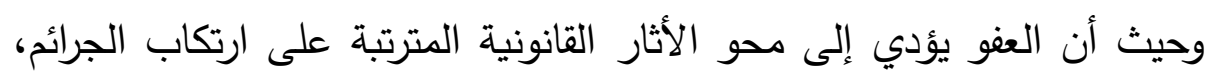

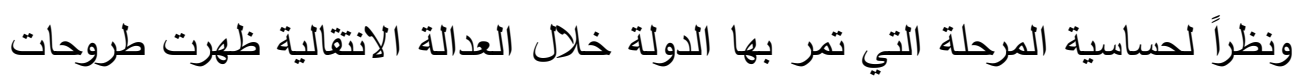

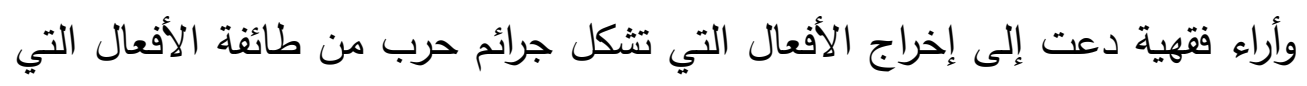

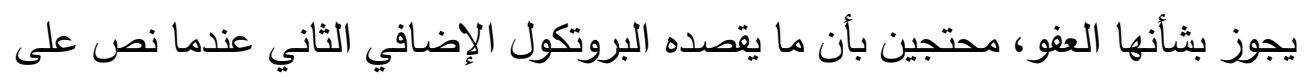

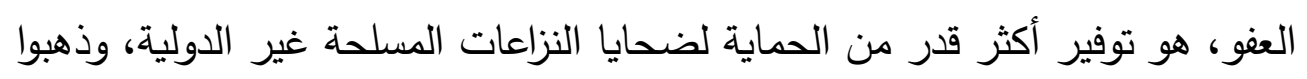

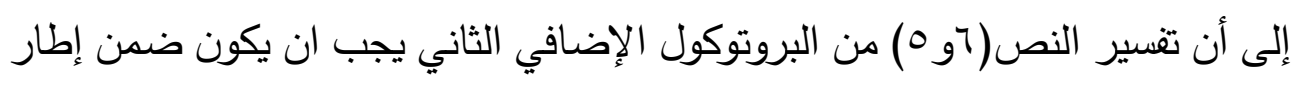

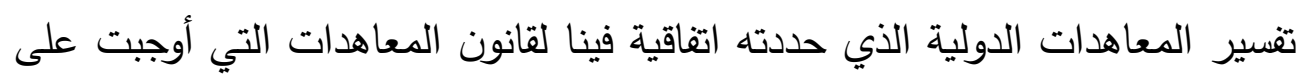

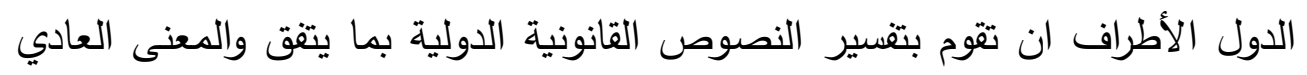

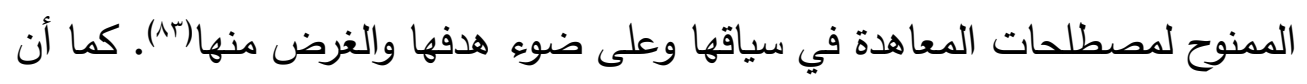




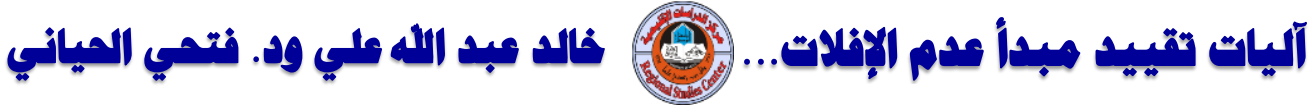

هناك العديد من مصادر القانون الدولي وسياسة الأمم المتحدة تذهب إلى عدم جواز اتخاذ تدابير العفو إذا كانت:

ا ـ تمنع مقاضاة أشخاص ربما كانوا مسؤولين جنائياً عن ارتكاب حرب أو إبادة جماعية أو جرائم ضد الإنسانية أو انتهاكات جسيمة لحقوق الإنسان، بما في ذلك المتعلقة

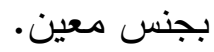

r. تتعارض مع حق الضحايا في الحصول على سبيل الانتصاف الفعال بما في ذلك

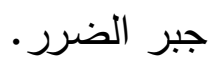

r. تقييد حق الضحايا والمجتمعات في معرفة الحقيقة بشأن انتهاكات القانون الدولي لحقوق الإنسان والقانون الدولي الإنساني. فضلاً عن ذلك يتعين وضع تدابير العفو التي تهدف إلى إعادة إرساء أسس الإنساني

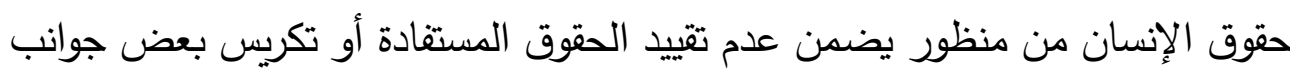

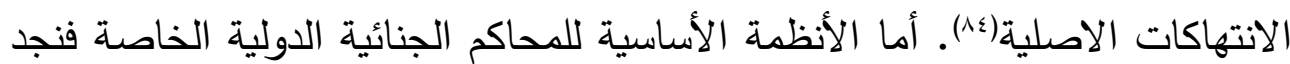

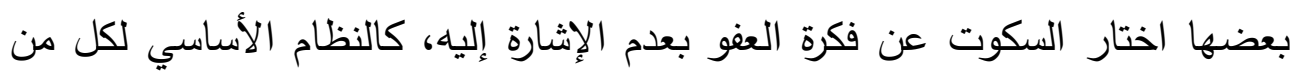

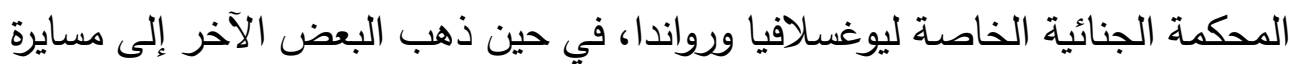
التطورات في المواقف الفقهية الدولية الرافضة لفكرة العفو عن الجرائم الدولية ونصت صراحة على ذلك، كما هو الحال بالنسبة للنظام الأساسي للمحكمة الخاصة بسيراليون(1) (1). كما اشترطت العديد من المعاهدات الدولية لحقوق الإنسان والقانون الدولي المصادق عليها من جانب الدول بشكل واسع، أن تضمن الدول الأطراف معاقبة مرتكبي الانتهاكات الدولية الجسيمة، إما باتخاذ الإجراءات الجنائية بحقهم في محاكمها المحلية

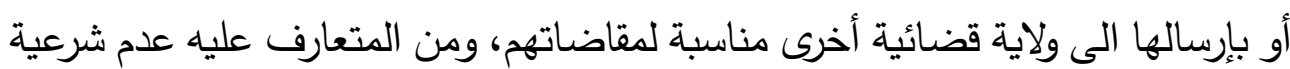
العفو الذي يتعارض مع الالتزامات الواردة في أية معاهدة، ذلك أن القانون الدولي

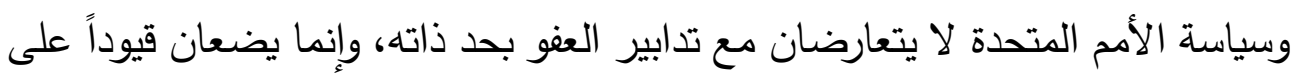
نطاق جوازه، فتدابير العفو يمكن أن تضع نهاية للصراعات المسلحة مع عدم جواز منح 
العفو لمرتكبي الجرائم الخطيرة(ش)، وأن من بين أهم التطبيقات للعفو هو العفو الذي

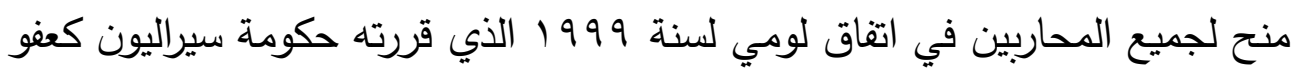

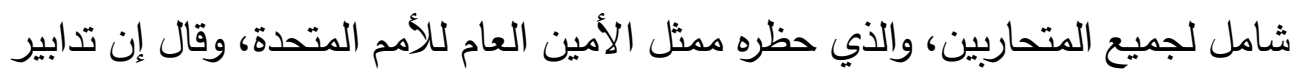

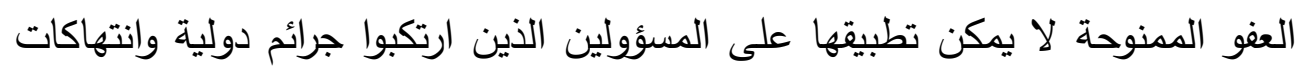

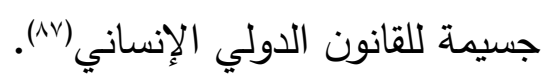

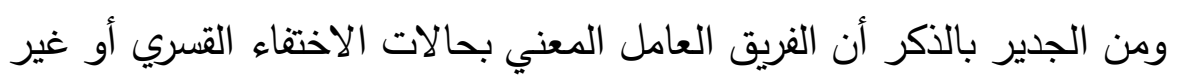

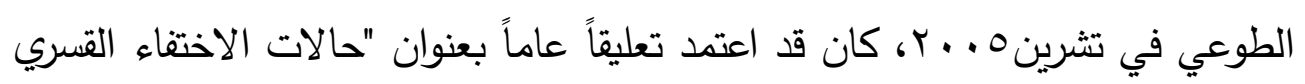

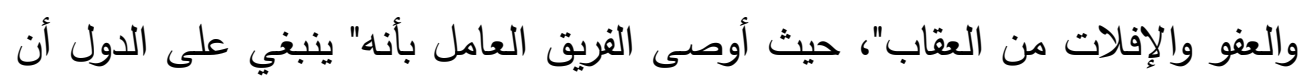

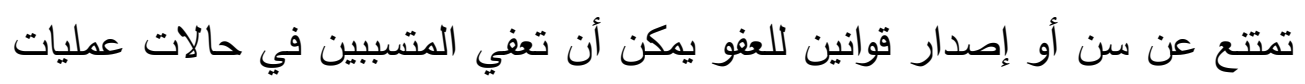

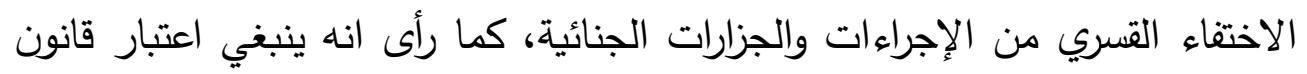

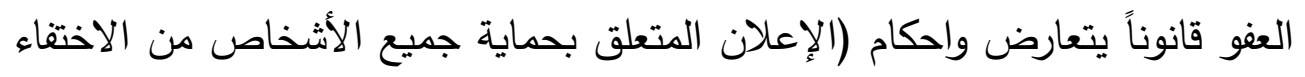

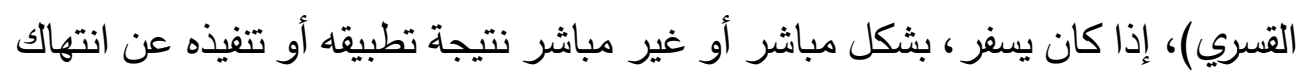

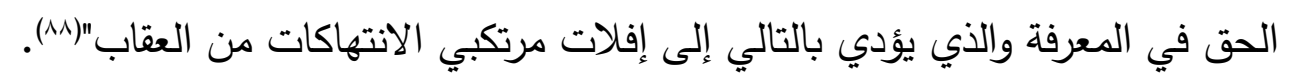
يرى الباحث أن تدابير العفو عن الجرائم والانتهاكات الجسيمة لحقوق الإنسان

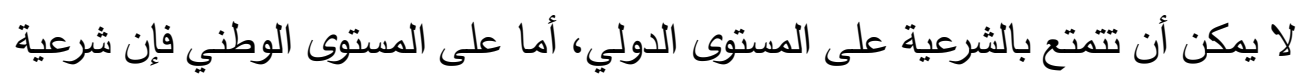

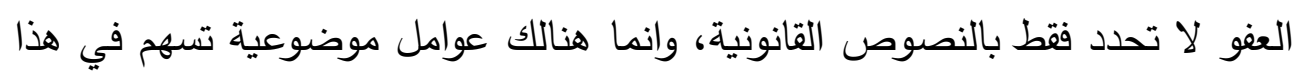

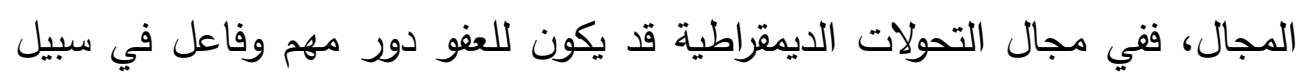

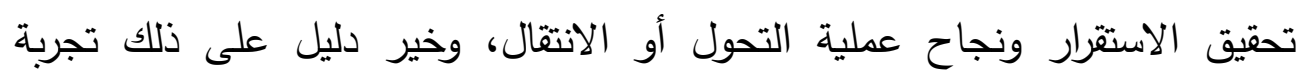

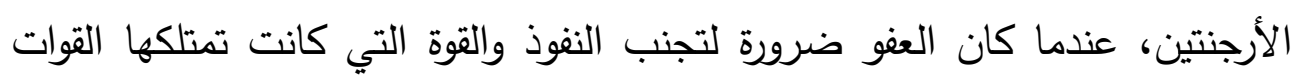

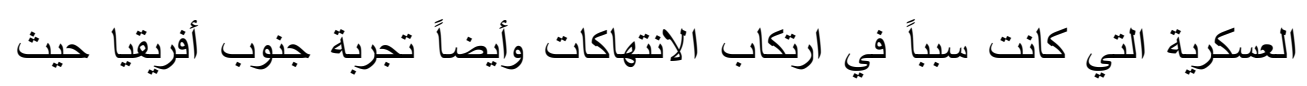

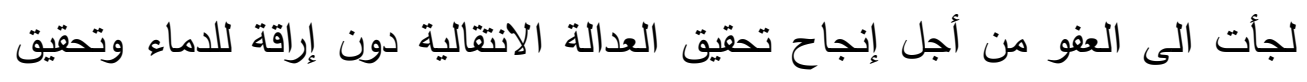

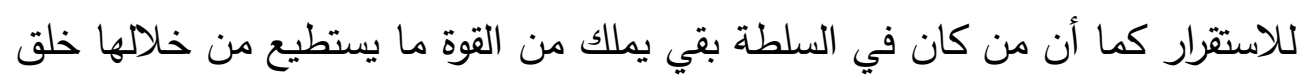

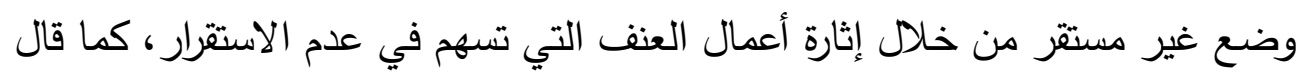
التس ديسموند توتو (مازالوا قادين على تخريب المسلسل). 


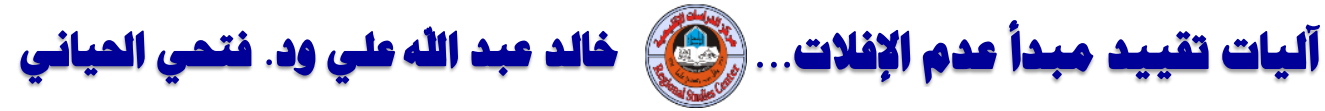

الفرع الثالث: دور تدابير العفو في تقييد مبدأ عدم الإفلات من العقاب خلال فترة العدالة الانتقالية

خلافاً للحصانة والتقادم الذي توجد نصوص اتفاقية دولية على عدم الاعتداد بهما، كقيود وموانع على المتابعة الجزائية ضد منتهكي حقوق الإنسان، فإنه لا توجد أية اتفاقية دولية تمنع بشكل مباشر وصريح إصدار العفو عن أية جريمة من الجرائم

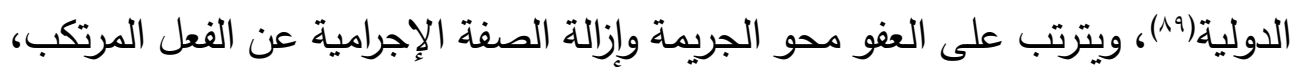
كما يمحو حكم الإدانة وكل ما يترتب عليه من آثار ، فإذا كان العفو قد صدر قبل رفع الدعوى فإنه يمنع من إقامتها أمام المحاكم، وإن كان قد صدر بعد رفع الدعوى فإن الاعوى تتقضي ويتوقف السير فيها بعد صدور العفو، وإن كان قد صدر العفو بعد الحكم فإنه يترتب على صدوره محو الحكم بالإدانة وإزالة جميع الآثار المترتبة عليه(·9.".

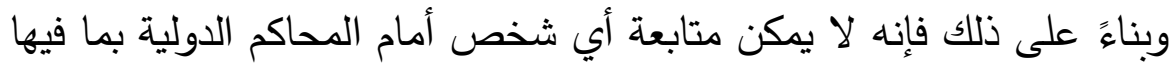
المحكمة الجنائية الدولية بعد صدور العفو عنه، مالم يتبين أن العفو المذكور لم يكن

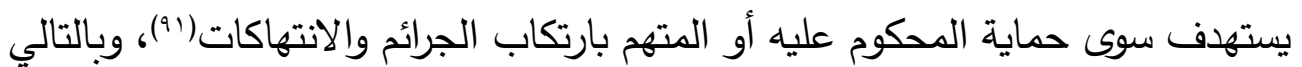
سوف نكون أمام حالة من حالات الإفلات من العقاب، والتي لا تقدم الجهات المسؤولة عنها عن إيجاد الذرائع والتبريرات لها، بوصف العفو إجراء سوف يسهم في دفع عجلة المصالحة الوطنية الى الأمام ويؤدي إلى استقرار النظام السياسي وتحقيق السلم الاجتماعي، بحيث أصبحت المصالحة والسلم والأمن والاستقرار في بعض السياقات بمثابة كلمة السر التي تستخدم لإعطاء الثرعية للإفلات من العقاب وكانت المرحلة الانتقالية والسلام والمصالحة والحقيقة مبررات استخدمت مجتمعة ومنفردة لتبرير العفو، لإله

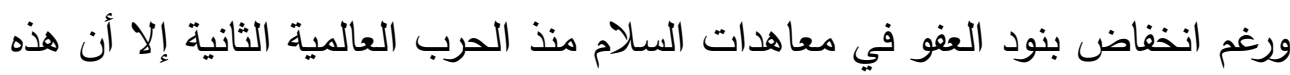
الدوافع والمبررات لم تفقد صلاحيتها، وتم منح العفو في ثلاث سياقات مختلفة هي: النزاع المسلح الدولي، والنزاع المسلح غير الدولي ،وفي حالة التحول من الدكتاتورية إلى الحكم الديمقراطي(جr)، واستخدم العفو أيضاً كورقة مساومة لحث منتهكي حقوق الإنسان على الموافقة على السلام والتخلي عن السلطة، وهو ما حدث في هاييتي(זّه، وأيضاً 
في اليمن إبان ما سمي بثورات الربيع العببي عندما تم توقيع اتفاق برعاية سعودية بين

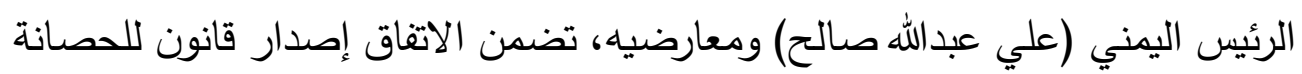

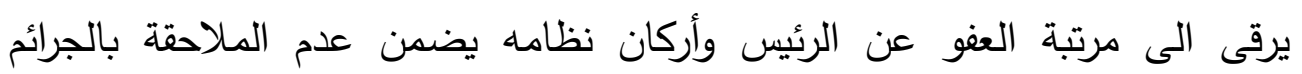

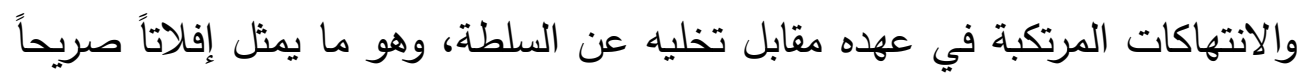

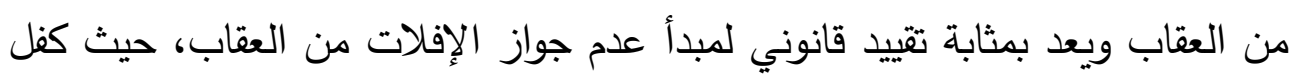

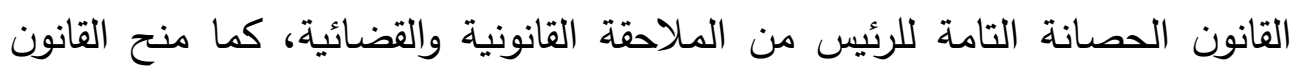

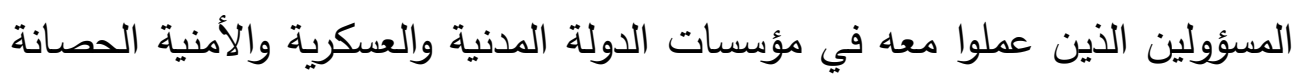

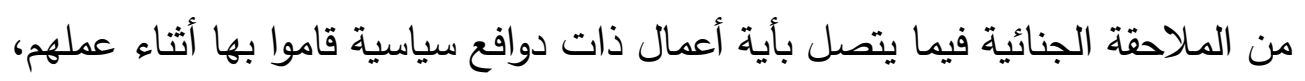

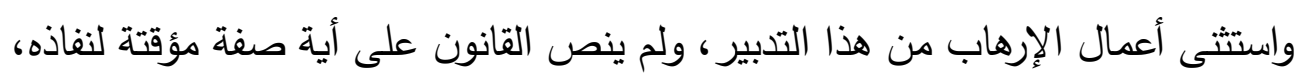

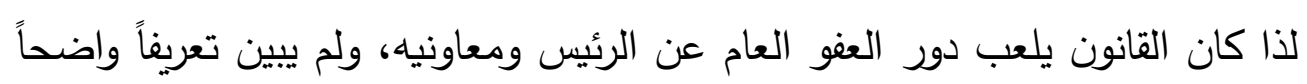

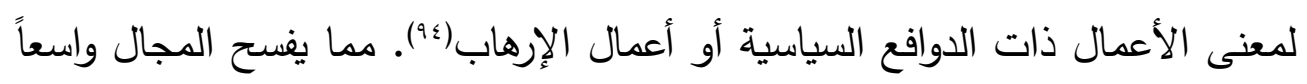

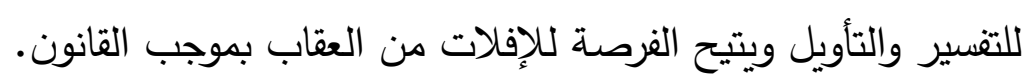

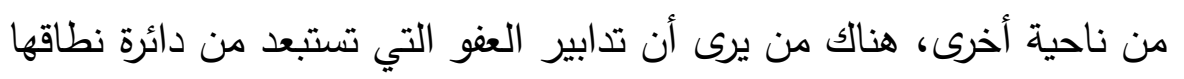

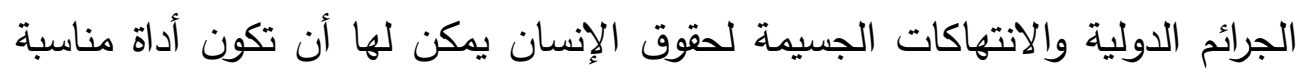

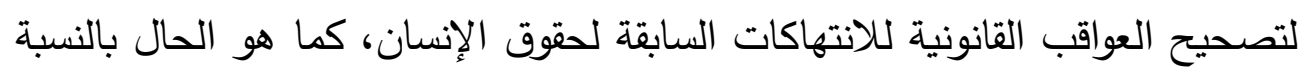

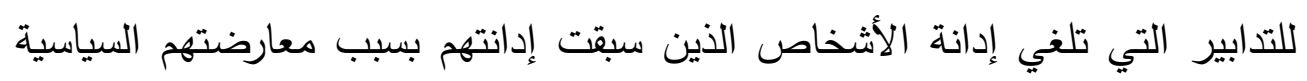

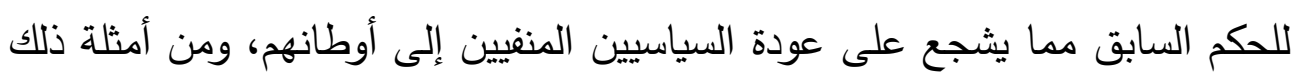

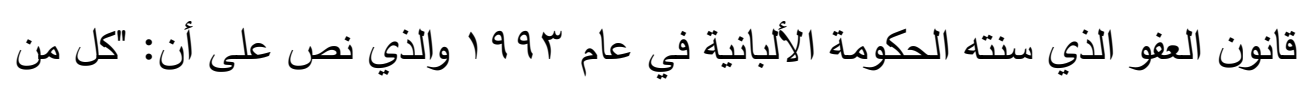

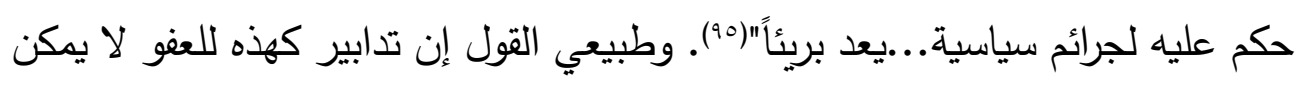

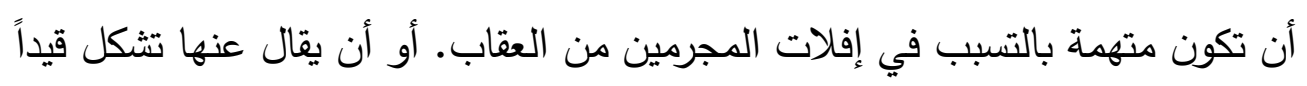

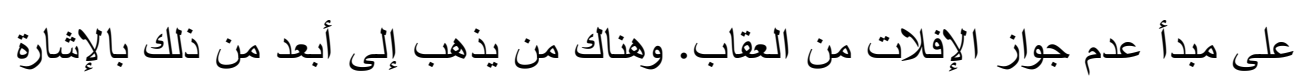

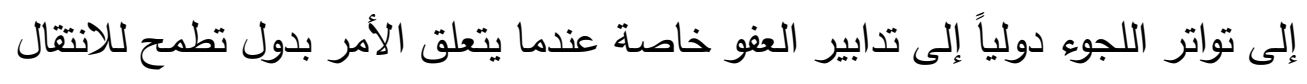

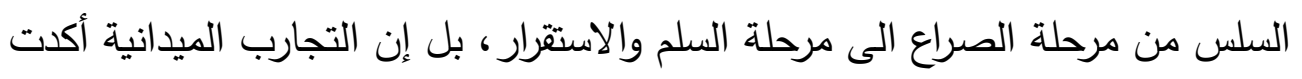

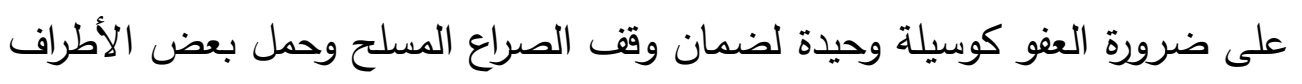




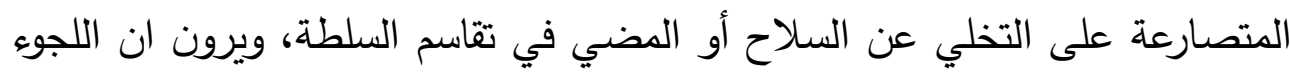

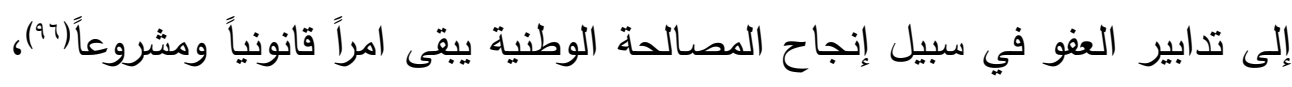

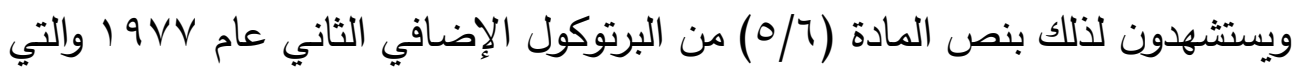

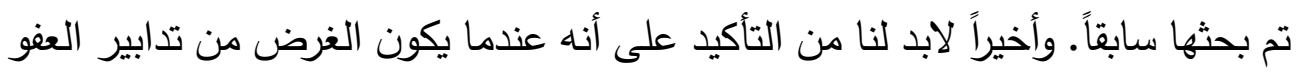

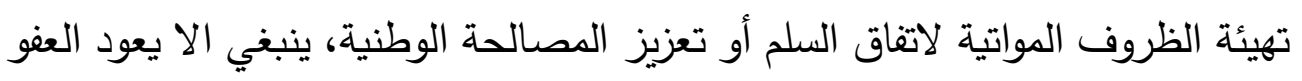

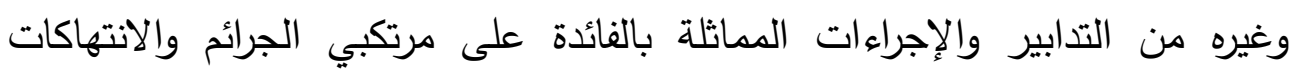

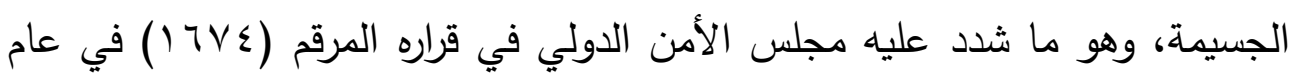

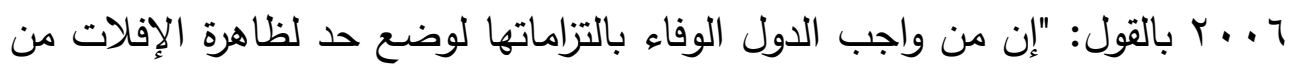

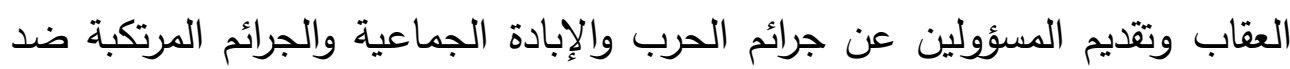

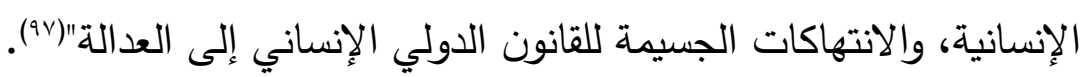

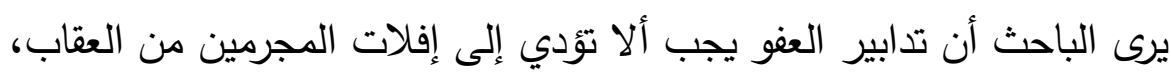

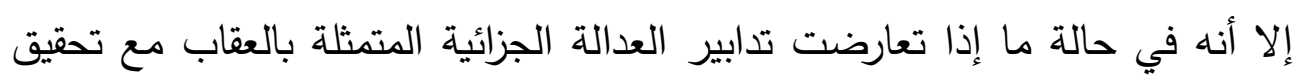
الاستقرار والسلم المجتمعي فلا مناص حينئذ من اللجوء إلى العفو حتى وإن أدى إلى إلى الدي

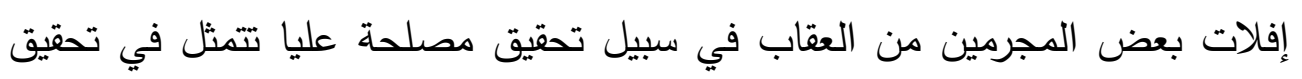

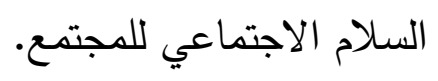

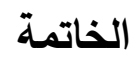

في ختام بحثا بثأن"آليات تقييد مبدأ عدم الإفلات من العقاب خلال فترة العدالة

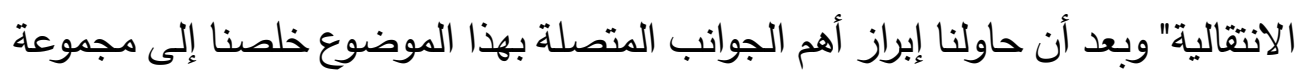

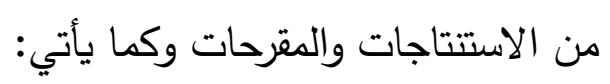

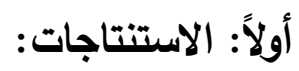

ا. يفرض على المرحلة الانتقالية إما السير في طريق العدالة الجزائية، ومحاسبة

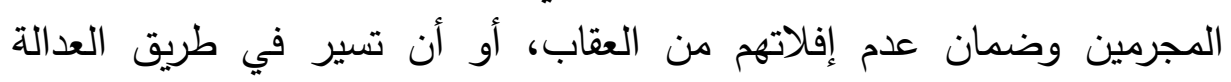

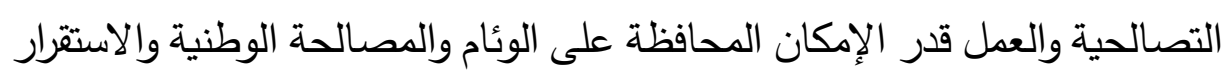

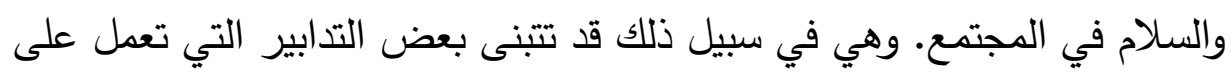

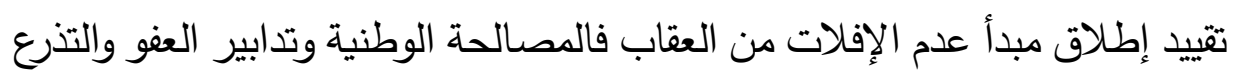

ץч. Regional Studies Journal, Vol.15, No.48, April 2021 (227-270) Print ISSN: 1813-4610 Online ISSN: 2664-2948 


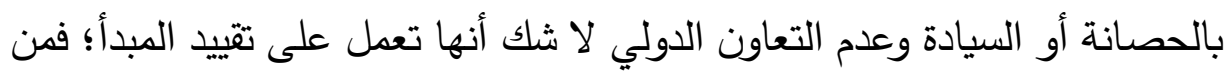

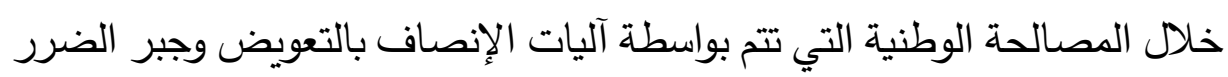

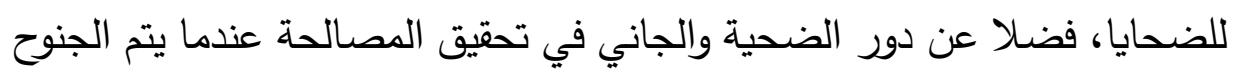

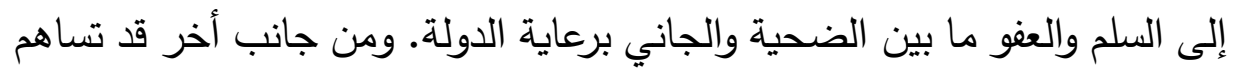

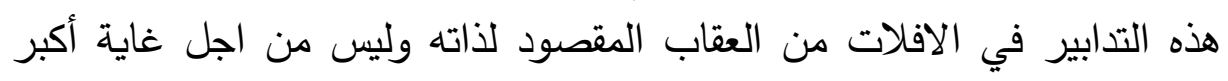
وضمن برنامج أثشمل يأخذ بنظر الاعتبار الضحن الضايا وحقوقهم.

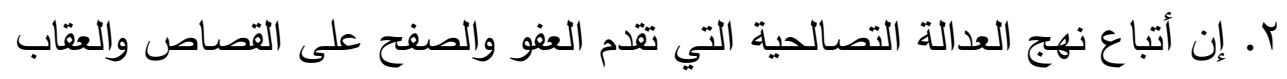

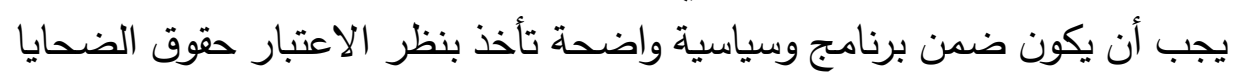

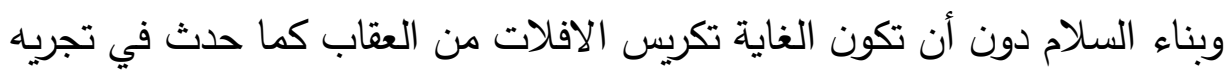

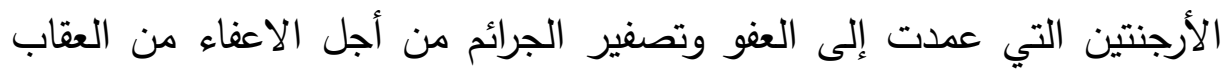

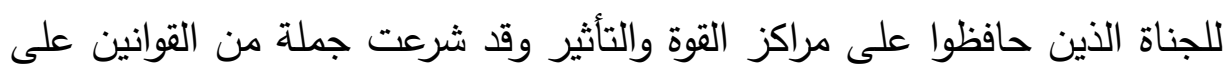

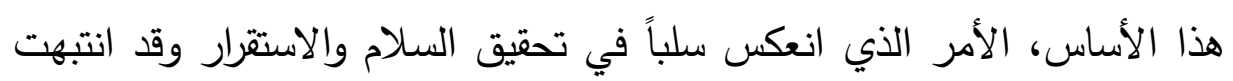

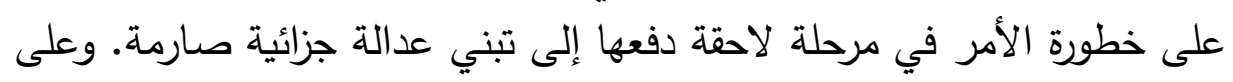

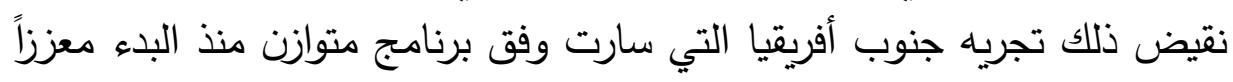

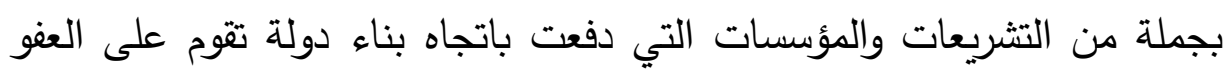

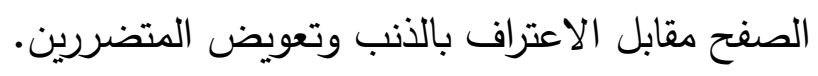

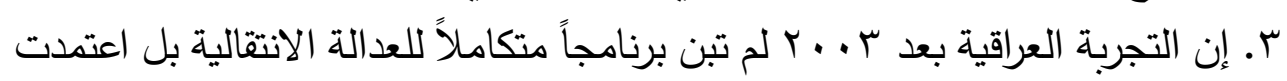

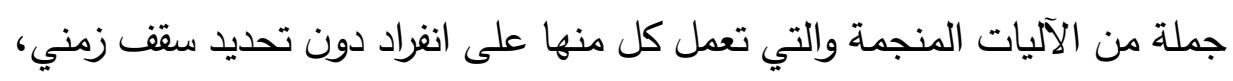

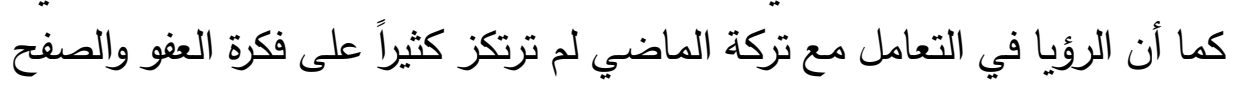

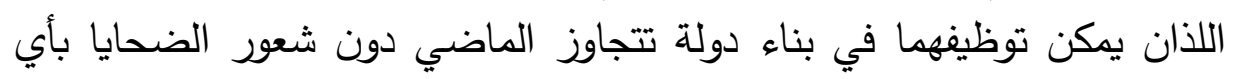

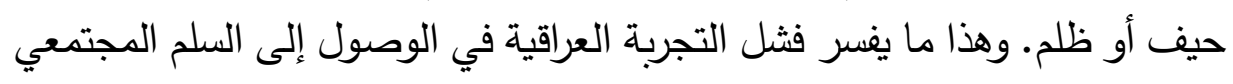

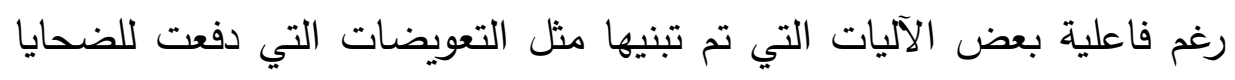

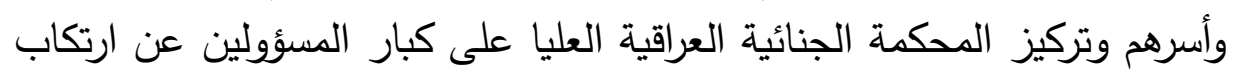

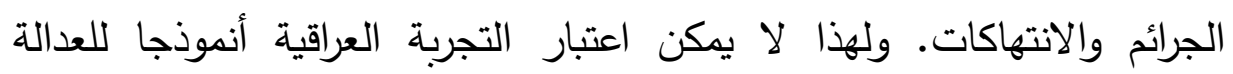

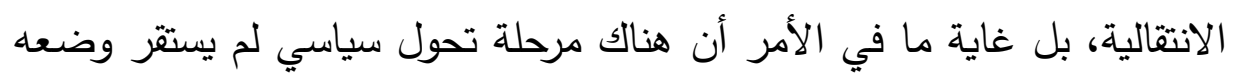
وتثظت فيه النزاعات التي تتطلب كل منها برنامجاً انتقالياً مفصلاً. 


\section{o}

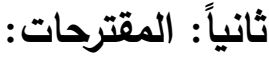

ا ـ على الدول التي تمر بمرحلة عدالة انتقالية تقييد مبدأ عدم الإفلات من العقاب في نطاق محدد لا يشمل مرتكبي الانتهاكات الجسيمة لحقوق الإنسان، والجرائم الأشد الأبد خطورة التي تمت الإشارة اليها في النظام الأساس للمحكمة الجنائية الدولية، كي الانياني لا يكون تقييد المبدأ وسيلة يتم من خلالها إفلات مرتكبي الانتهاكات النيات الجسيمة من

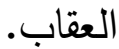

r. العمل على تفعيل الية التعاون الدولي مع المحكمة الجنائية الدولية من خلال

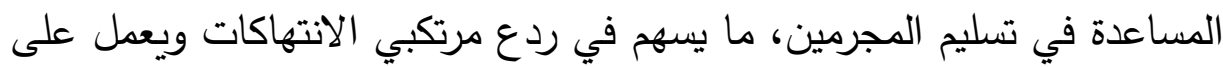

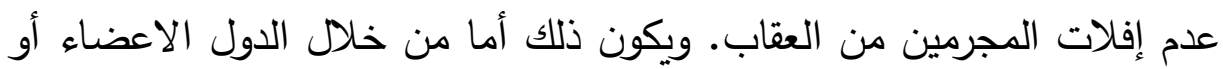
توقيع اتفاقيات بين المحكمة وبين الدول غير الاعضلاء.

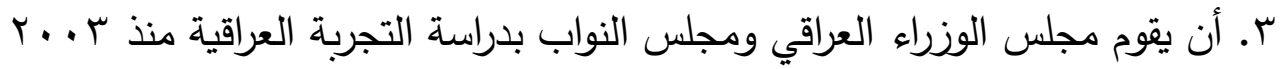

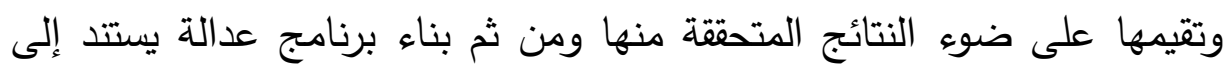
الواقع السياسي والاجتماعي والقانوني بغية تجاوز السلبيات والمضي قدماً باتجاه

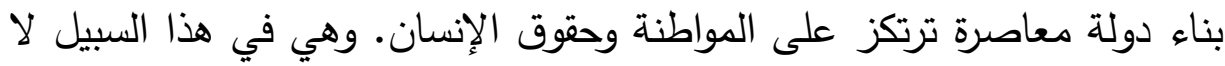

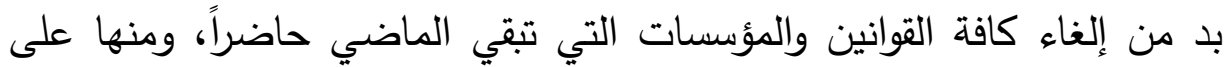
سبيل المثال الغاء قانون المساءلة والعدالة وتجاوز فكرة الاجتثاث. 
الهوامش والمصادر

(') عبد الإله القباقبي، تجارب العدالة الانتقالية في أمريكا اللاتينية: الثيلي، البرازيل، الأرجنتين- دراسة

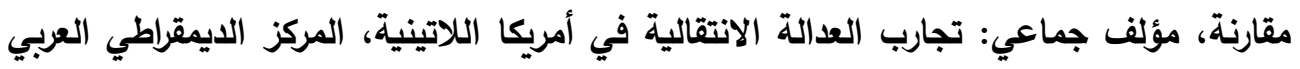

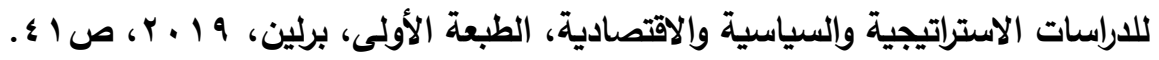
عمر الفاروق الحسيني، مبادئ علم الإجرام والعقاب، طبعة خاصة بيرنامج الدراسات القانونية بشعبة

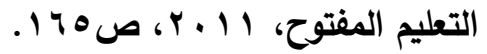

(ז) تعد تجربة الارجنتين من تجارب التحول الايمقراطي التي طبقت العدالة الجزائية، إذ عرفت البلاد

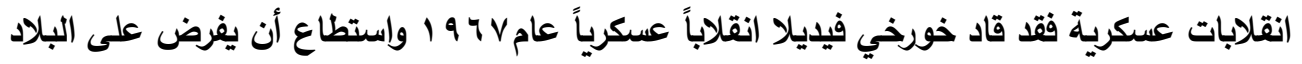

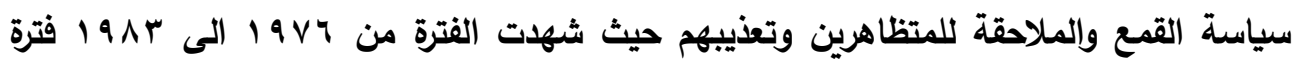

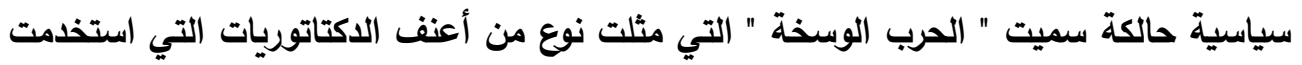

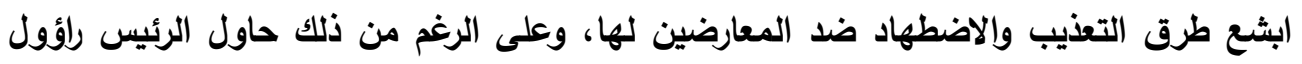

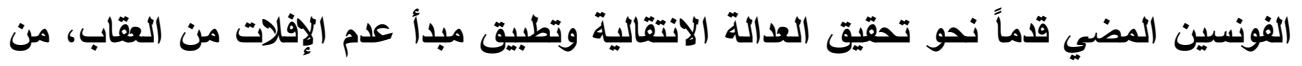

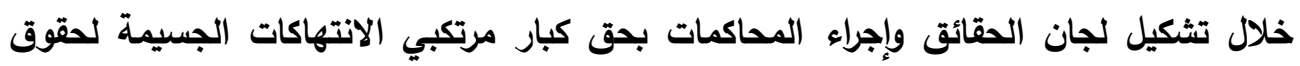

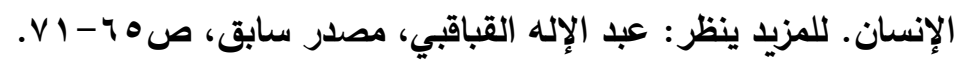

(4) الأمم المتحدة، مجلس حقوق الإنسان تقرير آلية الخبراء المعنية بحقوق الثعوب الاصلية، وقائع

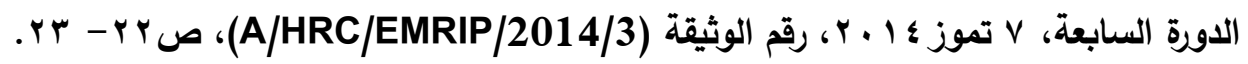
(•) الأمم المتحدة، المجلس الاقتصادي والاجتماعي (لجنة منع الجريمة والعدالة الجنائية)، مصدر سابق،

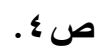

(1) الأمم المتحدة، التقرير الحادي عشر لمنع الجريمة والعدالة الجنائية (تعزيز إصلاح العدالة الجنائية

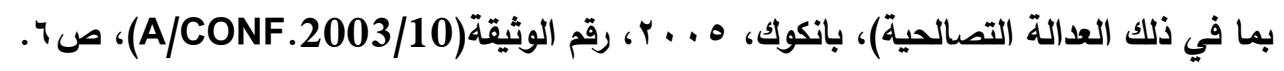
(v) الأمم المتحدة، المجلس الاقتصادي والاجتماعي (لجنة منع الجريمة والعدالة الجنائية)، وقائع الدورة

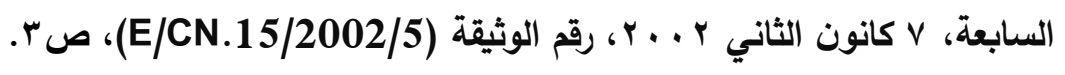




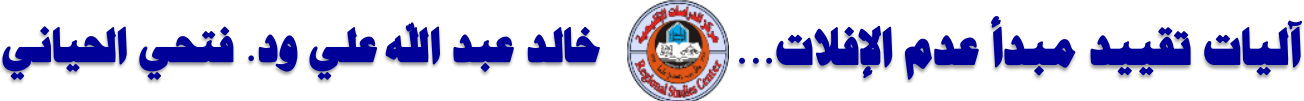

(^) عبد الرحمن بن النصيب، العدالة التصالحية البديل عن العدالة الجنائية، مجلة الفكر، كلية الحقوق . والعلوم السياسية، جامعة محمد خيضر، العدد الحادي عشر، بدون سنة نشر، ص 9هـ (9) الأمم المتحدة، المجلس الاقتصادي والاجتماعي، لجنة منع الجربمة والعدالة الجنائية، وقائع الدورة السابعة، Vكانون ال ثاني r . . r ، رقم الوثيقة (E/CN.15/2002/5)، ص ه.

(·) مواجهة الحقيقة(دليل ملحق)، دراسة منشورة على شبكة الدولية الانترنيت، متاحة على الرابط الآتي: Www.isip.orq

(') مولاي أحمد مولاي عبد الكريم، الأسس الفلسفية لمفهوم العدالة الانتقالية مقاربة أولية، بحث منشور

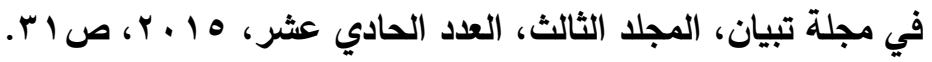

(ז'ا خالد الثرقاوي السموني، تجربة المغرب في العدالة الانتقالية والمصالحة والإنصاف، مقال منشور

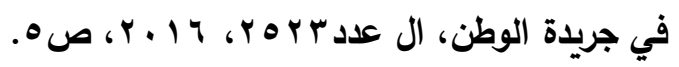

(זrا) القاضي ناصر عمران، العدالة التصالحية، مقال منشور في صحيفة القضاء الصادرة عن مجلس

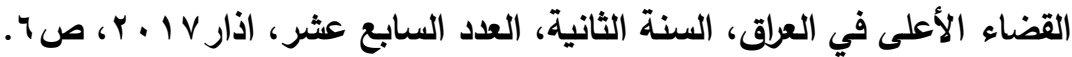

(؛؛) الأمم المتحدة، المجلس الاقتصادي والاجتماعي، الدورة الحادية والستين، وقائع الدورة الحادية والستين، مشباطه . . ץ. رقم الوثيقة (E/CN.4/2005/102/Add.1)، ص ץ ا

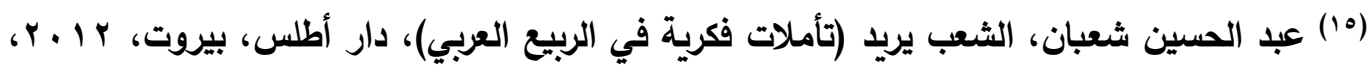

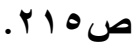

(1') خالد الشرقاوي السموني، مصدر سابق، صــ. (viv) الأمم المتحدة، مفوضية الأمم المتحدة لحقوق الإنسان، ادوات سيادة القانون لدول ما بعد الصراع

$$
\text { (لجان الحقيقة)، نيويورك- جنيف، } 7 \text {. . r ، ص r-r. }
$$

(1) نويل كالهون، معضلات العدالة الانتقالية في التحول من دولة شمولية الى دولة ديمقراطية، الطبعة

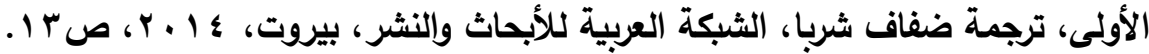
(9) رونالد ستايل ومارك فريمان، حدود العقاب (العدالة الانتقالية والتطرف العنيف) معهد العمليات

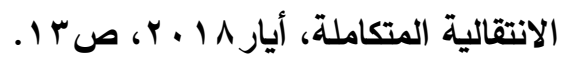

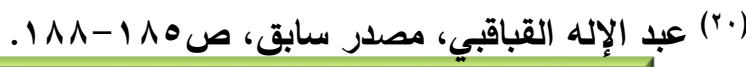

үчะ Regional Studies Journal, Vol.15, No.48, April 2021 (227-270) Print ISSN: 1813-4610 Online ISSN: 2664-2948 


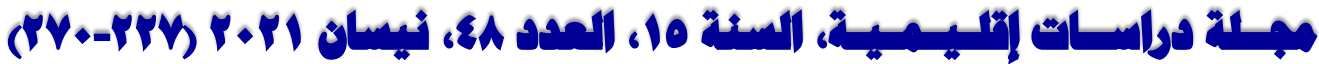

(r) أحمد شوقي بنيوب، العدالة الانتقالية بتونس أسس نظرية وتطبيقات عملية وتصورات مستقبلية،

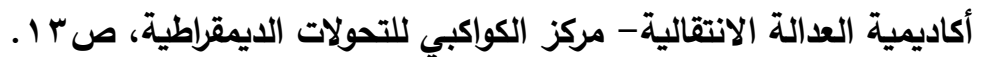

(r) دنيا هاتف مكي، العدالة الانتقالية في ظل التغيير في المنطقة العربية، مجلة العلوم السياسية، كلية

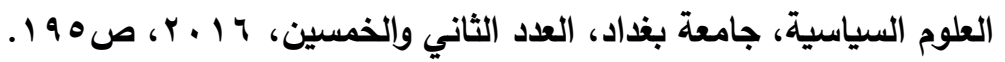

(rr) محمد عادل عسكر، المعايير الدولية للعدالة الانتقالية وآليات تطبيقها، الطبعة الأولى، مركز الدراسات

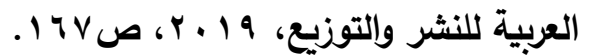

$$
\begin{aligned}
& \text { (r\&) مولاي أحمد مولاي عبد الكريم، مصدر سابق، ص • r. }
\end{aligned}
$$

(ro) بوجعبوط المصطفى، المصالحة الوطنية من خلال تجارب العدالة الانتقالية: مظاهر تحقيق الوحدة

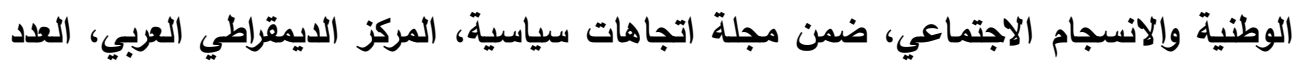

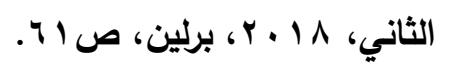

(ب) روزالين وارف وإخرين، الواقع الراهن وتحديات العدالة الانتقالية كجزء من بناء سلام مستدام في

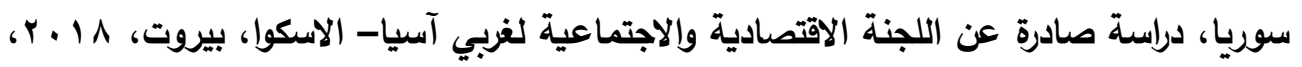

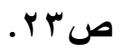

الأل (rV) عامر حادي عبد الله الجبوري، العدالة الانتقالية ودور الأمم المتحدة في إرساء مناهجها، الطبعة

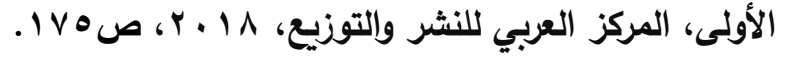

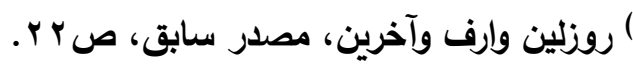

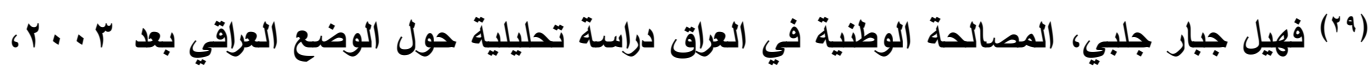

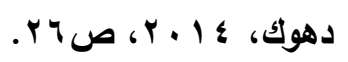

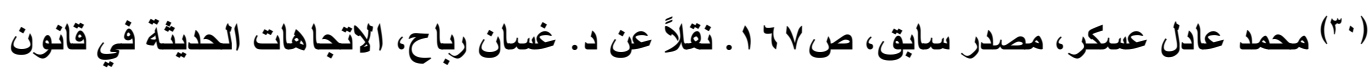

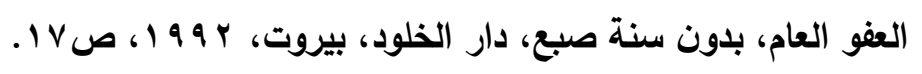

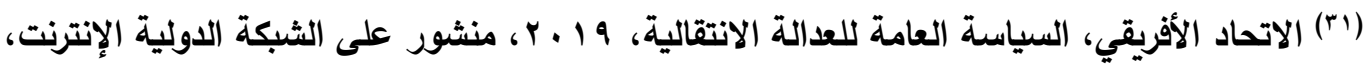

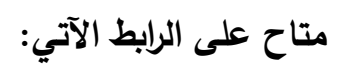

www.au.int.org/documents3 


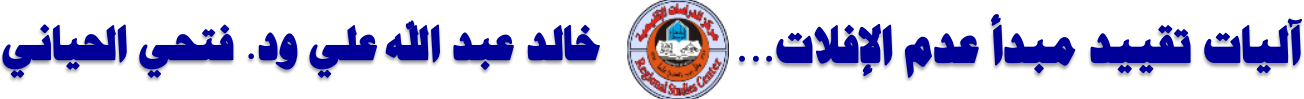

(rr) حافظ أبو سعدة، العدالة الانتقالية في مصر: التحديات والفرص، مؤلف جماعي: العدالة الانتقالية

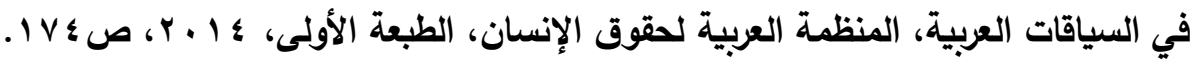

(rT) مصطفى الريسوني، جبر الضرر في التجربة المغربية من هيئة التحكيم الى هيئة الإنصاف والمصالحة، مؤلف جماعي: العدالة الانتقالية في السياقات العربية، المنظمة العربية لحقوق هيطية

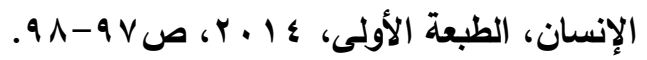

(ء) صلاح عبد الرحمن الحديثي و سلامة طارق الشعلان، حماية حقوق الإنسان في منظمة الأمم

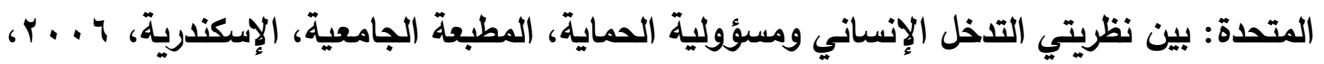
$.1 \leq 1-1 \leqslant \cdot 0$

(•)" مرسي أحمد عبد الله أمعبد، المصالحة الوطنية ومقتضيات العدالة الجنائية الدولية، رسالة ماجستير،

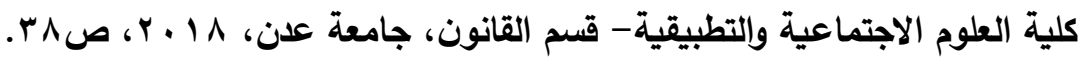

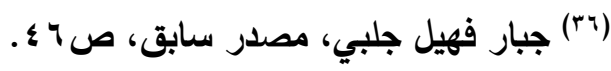

(rv) صلاح عبد الرحمن الحديثي وسلامة طارق الشعلان، مصدر سابق، ص^ ب ا.

$$
\text { ( }
$$

(9) الطاهر سـعود، المصـالحة الوطنية في الجزائر : التجربة والمكاسـب، مجلة سـياسـات عربية، العدد

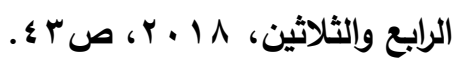

(·) ينظر: المادة (به)، النظام الأساسي للمحكمة الجنائية الدولية.

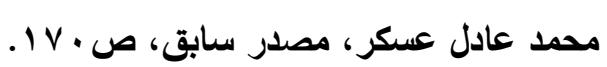

(r) مصطفى البوشاشي، التجربة الجزائرية من منظور العدالة الانتقالية، مؤلف جماعي: العدالة الانتقالية

في السياقات العربية، المنظمة العربية لحقوق الإنسان، الطبعة الأولى، ؛ 1 ـ ץ، ص 11 ا.

(r) كريمة الصديقي، تجربة العدالة الانتقالية في السلفادور، مؤلف جماعي: تجارب العدالة الانتقالية في أمريكا اللاتينية، المركز الديمقراطي العربي للدراسات الاستراتيجية والسياسية والاقتصادية، الطبعة

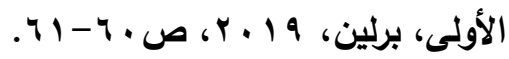

(؛ ؛) مركز البيان، المصالحة الوطنية في العرلق، سلسلة إصدارات مركز البيان للاراسات والتخطيط، بغداد، 


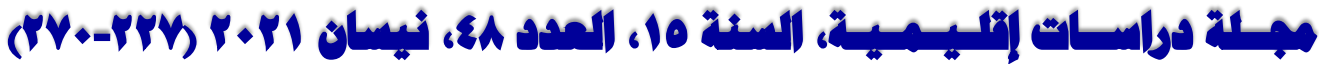

(؛ ؛ ؛تار جابر الجابري، المصالحة الوطنية وأثرها في تحميم العنف في العرلق، مجلة الدراسات الدولية،

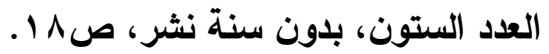

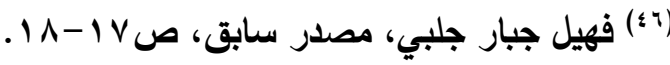

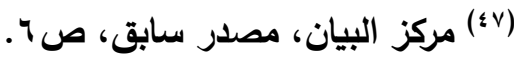

$$
\begin{aligned}
& \text { (^) فهيل جبار جلبي، مصدر سابق، ص . } 0 .
\end{aligned}
$$

ســد فتح الله، العدالة الانتقالية في العرق، مؤلف جماعي بعنوان العدالة الانتقالية في السـياقات

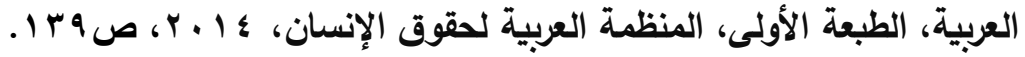

(0) (مركز البيان، مصدر سابق، ص 7.

(10) ينظر: نص مشروع المصالحة الوطنية، منشور على الثبكة الدولية الإنترنت، متاح على الرابط الآتي:

www.cabinet.iq

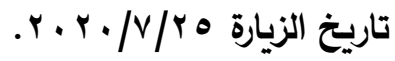

(م) عيسى إسماعيل عطية، دور المصالحة الوطنية في تفعيل السياسة الخارجية العراقية، بحث منثور

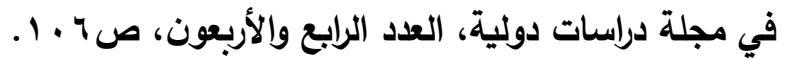

(بام) خيري عبد الرزلق جاسم، العملية السياسية في العلق ومشكلات الوصول إلى دولة القانون، مطبعة

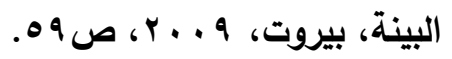

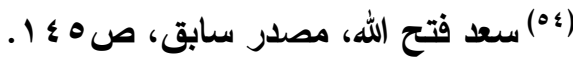

(00) الأمم المتحدة، مفوضية الأمم المتحدة لحقوق الإنسان، أدوات سيادة القانون لاول ما بعد الصراع

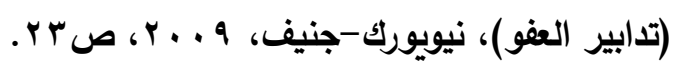

(10) قو بدر الثبي، الموازنة بين العقوبة والعفو، أطروحة دكتوراه، كلية الحضارة الإسلامية والعلوم

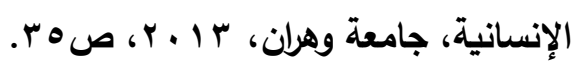

الانيانة، (مام لعناني، العفو عن الجرائم الدولية وتأثيره على فعالية مسار العدالة الانتقالية، مجلة العلوم

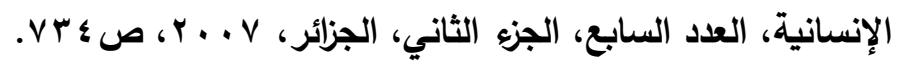

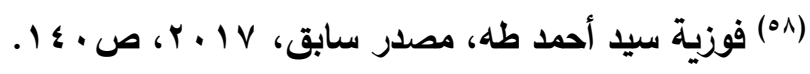




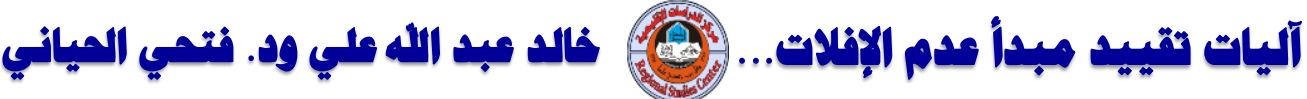

(9ه) الأمم المتحدة، مفوضية الأمم المتحدة لحقوق الإنسان، أدوات سيادة القانون لدول ما بعد الصراع

$$
\text { (تدابير العفو)، مصدر سابق، صأَ. }
$$

(·r) عبد الله عزوزي، مبدأ عدم الافلات من العقاب في القانون الدولي الجنائي، رسـالة ماجسـتير، كلية

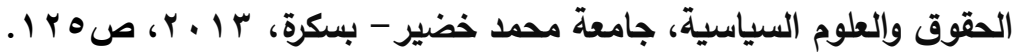

(اי) نصـر الين بوسـماحة، حقوق ضـحايا الجرائم الدولية، دار الفكر الجامعي، الطبعة الأولى، V . . Y،

$$
\begin{aligned}
& \text { ص .1. } \\
& \text { (r") قوبلر الشبي، مصدر سابق، ص VY. }
\end{aligned}
$$

(זיا) الأمم المتحدة، مفوضية الأمم المتحدة لحقوق الإنسـان، أدوات سيادة القانون لاول ما بعد الصراع

$$
\begin{aligned}
& \text { (تدابير العفو)، مصدر سابق، صـ^. }
\end{aligned}
$$

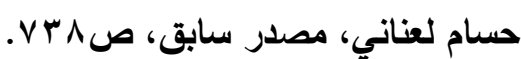

(70) الأمم المتحدة، مفوضية الأمم المتحدة لحقوق الإنسان، أدوات سيادة القانون لدول ما بعد الصراع

$$
\text { (تدابير العفو)، مصدر سابق، ص } 9 .
$$

ســمر الحصـري، أحكام تسـليم المجرمين في فلسـطين، رســالة ماجسـتير، كلية الحقوق، جامعة

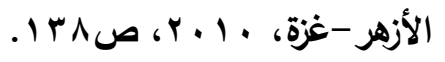

$$
\begin{aligned}
& \text { ("v نصرالدين بوسماحة، مصدر سابق، ص ץ ـ 1 . }
\end{aligned}
$$

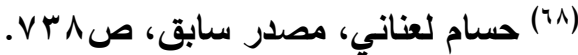

(97) الأمم المتحدة، مفوضية الأمم المتحدة لحقوق الإنسان، أدوات سيادة القانون لاول ما بعد الصراع

$$
\begin{aligned}
& \text { (تدابير العفو)، مصدر سابق، ص^^. } \\
& \text { (v•) (الحبيب بلكوش، مصدر سابق، ص \& \& . }
\end{aligned}
$$

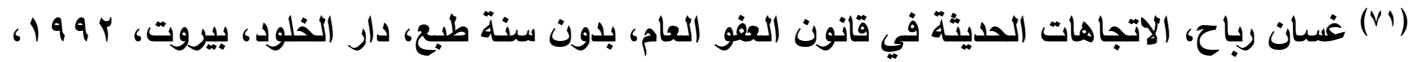
ט

(rr) محمد علي سالم جاسم وصالح شريف مكتوب، إثكاليات تطبيق قانون العفو وموقف القضاء العراقي، بحث منشور في مجلة المحقق الحلي، العدد الأول، السنة السادسة، صس ا.

५ ^ Regional Studies Journal, Vol.15, No.48, April 2021 (227-270)

Print ISSN: 1813-4610 Online ISSN: 2664-2948 


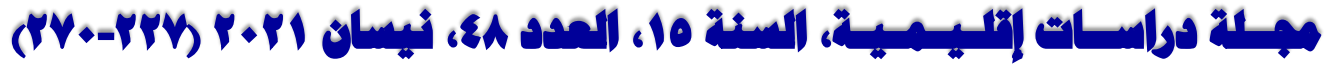

(تآناق السلام يلزم الطرفين باستثناء جرائم الحرب وجرائم الإبادة الجماعية من نطاق العفو لكن المرسوم لا يستبعد هذه الجرائم بصورة صريحة في حين يستثي المرسوم عدة جرائم ينص عليها القانون المحلي وهي شبيهة بجرائم الحرب كالمتعلقة بالأسرى. ينظر : الأمم المتحدة، مفوضية الأمم المتحدة لحقوق الإنسان، أدوات سيادة القانون لدول ما بعد الصراع (تدابير العفو)، نيويورك-

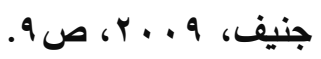
(؛ء) إقامة العدل وسـيادة القانون واللايمقراطية، تقرير الفريق العامل للدول المعني بإقامة العدل، مجلس

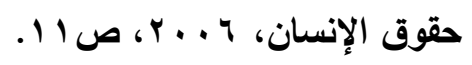

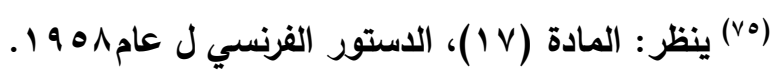

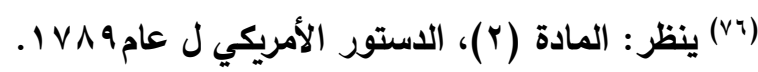

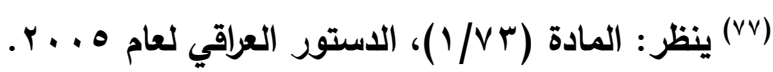

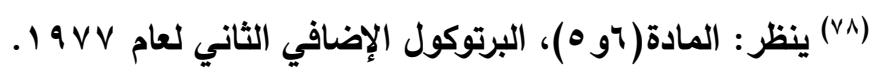

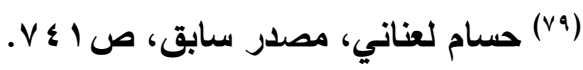

(•^دوقية دارانان، العدالة في المرحلة الانتقالية والمحكمة الجنائية الدولية، بحث منشور في مجلة اللجنة

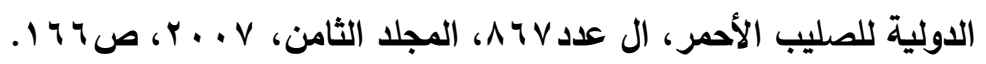

(ا^) جون ماري هنكرتس ولويز دوزو الابيلا، القانون الدولي الإنساني العرفي، المجلد الأول، منشورات

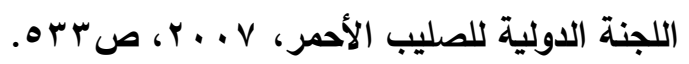

(ז^) ياسمين نقبي، العفو عن الجرائم الحرب وتعيين حدود الإقرار الدولي، مختارات من المجلة الدولية للصليب الأحمر، منشورات اللجنة الاولية للصليب الأحمر، جنيف، ب . . Y، ص ه ؛.

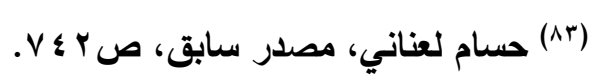

(๕^) الأمم المتحدة، مفوضية الأمم المتحدة لحقوق الإنسان، أدوات سيادة القانون لدول ما بعد الصراع

$$
\begin{aligned}
& \text { (تدابير العفو)، مصدر سابق، ص } 1 \text { ا. } \\
& \text { (^) حسام لعناني، مصدر سابق، ص ؟ \& V. }
\end{aligned}
$$

(ז^) الأمم المتحدة، مفوضية الأمم المتحدة لحقوق الإنسان، أدوات سيادة القانون لدول ما بعد الصراع

$$
\text { (تابير العفو)، مصدر سابق، صع ع ع. }
$$

ү ч Regional Studies Journal, Vol.15, No.48, April 2021 (227-270) Print ISSN: 1813-4610 Online ISSN: 2664-2948 


\section{ons

مارية عمراوي، ردع الجرائم الدولية بين القضاء الدولي والقضاء الوطني، أطروحة دكتوراه، كلية

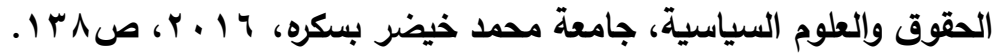

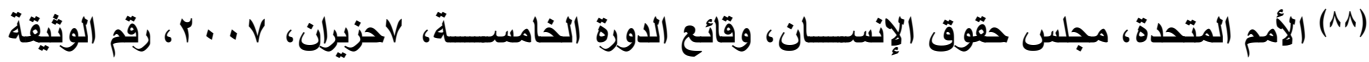
. V ص(A/HRC/5/7)

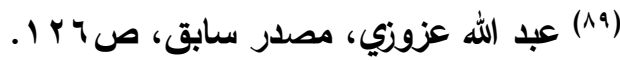

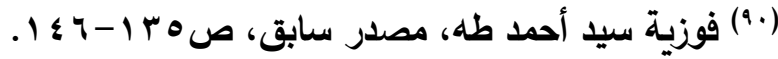
(9) عبد الله عزوزي، مصدر سابق، ص 9 ا ا.

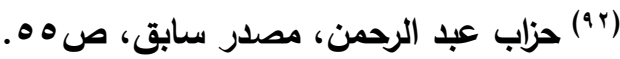

(ז؟) من أجل تحقيق السلام في هاييتي وحث الممسكين بالسلطة فيها على تحقيق الانتقال الديمقراطي السلمي توصل مجلس الأمن في عام ب9 9 ا إلى اقرار الاتفاق المسمى (اتفاق حكام الجزيرة)، بين السلطة والمعارضة، والذي نص على العفو عن أعضاء النظام العسكري المتهمين بارتكاب جرائم

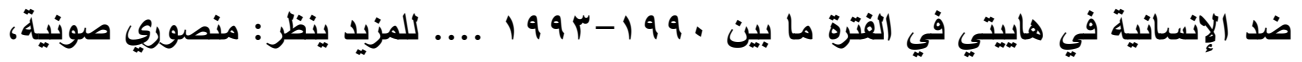

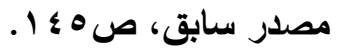

(؛و) منظمة العفو الاولية، قانون الحصانة من الملاحقة القانونية والقضائية اليمني خرق للالتزامات

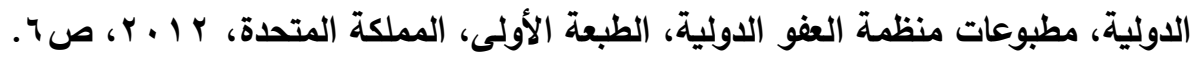
(90) الأمم المتحدة، مفوضية الأمم المتحدة لحقوق الإنسـان، أدوات سيادة القانون لاول ما بعد الصراع (تدابير العفو)، مصدر سابق، ص \& ؟ .

شــــريفة تريكي، أفريقيا والعدالة الجنائية الدولية، أطروحة دكتوراه، كلية الحقوق، جامعة الجزائر، (94) $.0 V I D$.

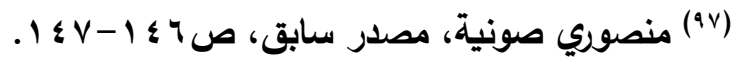

